\title{
Nitrous oxide from fungal denitrification \\ - Pure culture and soil studies using stable isotope and microbial inhibitor approaches
}

\author{
Dissertation \\ zur Erlangung des Doktorgrades \\ der Fakultät für Agrarwissenschaften \\ der Georg-August-Universität Göttingen
}

vorgelegt von

Lena Rohe

geboren in Haselünne 
D 7

1. Referentin/Referent: Prof. Dr. Nicole Wrage-Mönnig

2. Korreferentin/Korreferent: Prof. Dr. Klaus Dittert

Tag der mündlichen Prüfung: 22.05.2014 
Chapter 1:

General introduction $\quad 1$

Introduction 1

Objectives 10

Experimental concept 10

References 11

Chapter 2:

Fungal oxygen exchange between denitrification intermediates

$\begin{array}{lr}\text { and water } & 16\end{array}$

Introduction 17

Experimental 20

Results 24

Discussion $\quad 28$

Conclusions 31

Acknowledgements $\quad 32$

References 32

Chapter 3:

Dual isotope and isotopomer signatures of nitrous oxide

from fungal denitrification - a pure culture study 35

Introduction 36

Materials and Methods $\quad 38$

Results $\quad 42$

Discussion $\quad 45$

Conclusions $\quad 55$

Acknowledgements $\quad 56$

References $\quad 56$

Chapter 4:

Comparing modified substrate induced respiration with selective inhibition (SIRIN) and $\mathrm{N}_{2} \mathrm{O}$ isotope methods to estimate $\mathrm{N}_{2} \mathrm{O}$ production of fungal denitrification in three arable soils 60

Introduction 61

Materials and Methods 63

Results $\quad 69$

Discussion $\quad 78$

Conclusions $\quad 83$

References $\quad 84$ 
Chapter 5:

General discussion

Discussion

References

Summary

93

Zusammenfassung 95

Curriculum vitae 98

List of publications 99

Danksagung

100 


\section{General introduction}

\section{$\underline{\text { Introduction }}$}

\section{Environmental impact of nitrous oxide}

The impact of nitrous oxide $\left(\mathrm{N}_{2} \mathrm{O}\right)$ in the atmosphere became clear in the 1970s, when Crutzen observed its contribution to the depletion of the stratospheric ozone layer (Crutzen, 1970, 1972; Crutzen and Ehhalt, 1977). It was the same decade when $\mathrm{N}_{2} \mathrm{O}$ was found to be one of the heat-trapping greenhouse gases (Wang et al., 1976). Nowadays, besides carbon dioxide $\left(\mathrm{CO}_{2}\right)$, methane $\left(\mathrm{CH}_{4}\right)$ and halocarbons, the importance of $\mathrm{N}_{2} \mathrm{O}$ contribution to the global climate change induced by human activity is well known (IPCC, 2013). While its concentration in the atmosphere is about one thousand times smaller than that of $\mathrm{CO}_{2}$, the warming potential of $\mathrm{N}_{2} \mathrm{O}$ is about 298 times greater than that of $\mathrm{CO}_{2}$. Thus, $\mathrm{N}_{2} \mathrm{O}$ has the third largest impact on anthropogenic greenhouse gas emissions (IPCC, 2013). Prior to the beginning of the industrial era, $\mathrm{N}_{2} \mathrm{O}$ levels in the atmosphere were relatively constant. Natural sources for $\mathrm{N}_{2} \mathrm{O}$ are oceans (35\%), soils under natural vegetation (60\%) and atmospheric chemical reactions (5\%) (IPCC, 2013) and its atmospheric concentration amounted in preindustrial times about 270 ppb. However, until 2011 the $\mathrm{N}_{2} \mathrm{O}$ concentration in the atmosphere increased up to $324 \mathrm{ppb}$ (IPCC, 2013). Anthropogenic sources account for up to $39 \%$ of all global $\mathrm{N}_{2} \mathrm{O}$ emissions in 2006, while agricultural soils comprised most of it (IPCC, 2013) (Figure 1). Direct anthropogenic $\mathrm{N}_{2} \mathrm{O}$ emissions from agriculture come from the $\mathrm{N}$ fertilization of soils and livestock manure (59\%, Figure 1), while rivers, estuaries and coastal zones contribute to indirect anthropogenic emissions of agriculture due to fertilizer leaching and runoff (9\%) (Del Grosso et al., 2008; IPCC, 2013; Well and Butterbach-Bahl, 2010). Consequently agricultural activity constitutes the most anthropogenic emissions of $\mathrm{N}_{2} \mathrm{O}$ (68\%). Other anthropogenic sources for $\mathrm{N}_{2} \mathrm{O}$ are industry and fossil fuels, burning of biomass, human excreta and atmospheric deposition, which contribute about 32\% (IPCC, 2013). 


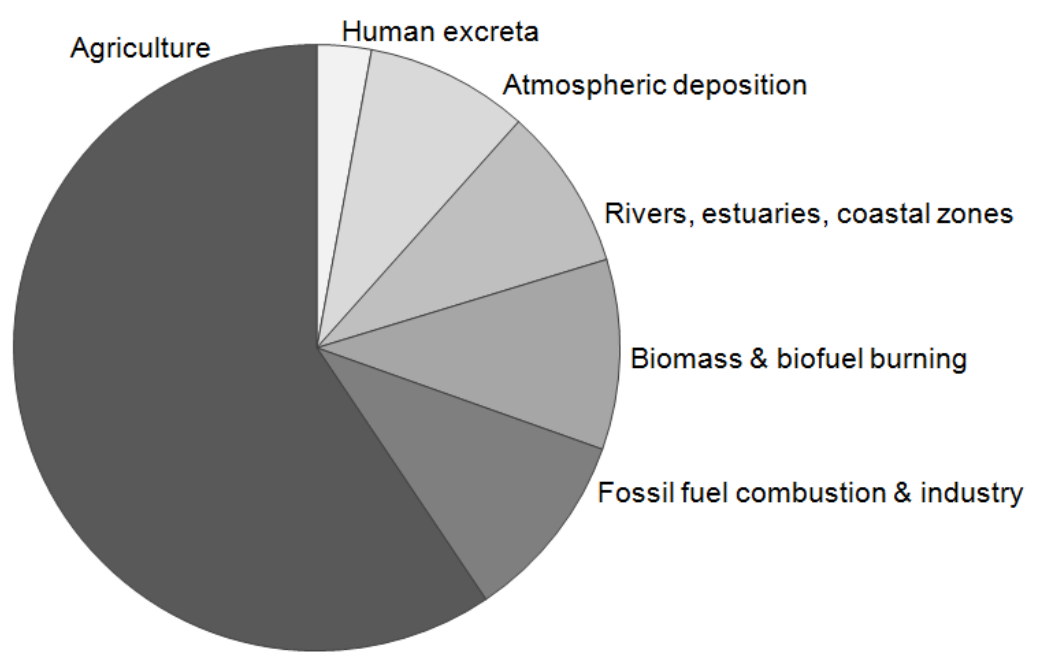

Figure 1: Percentage of global anthropogenic emissions of nitrous oxide $\left(\mathrm{N}_{2} \mathrm{O}\right)$ based on 6.9 Tg $\mathrm{N} \mathrm{yr}^{-1}$ total anthropogenic $\mathrm{N}_{2} \mathrm{O}$ emissions in 2006 (IPCC, 2013).

Improving knowledge about process dynamics controlling $\mathrm{N}_{2} \mathrm{O}$ emissions is one of the goals to find mitigation strategies of $\mathrm{N}_{2} \mathrm{O}$ emissions from anthropogenic sources. There is only minor consideration of chemical $\mathrm{N}_{2} \mathrm{O}$ production in soil, called chemodenitrification. It occurs under acidic conditions $(\mathrm{pH}<5)$ and describes the destruction of nitrite $\left(\mathrm{NO}_{2}{ }^{-}\right)$and produces predominantly nitric oxide (NO) (Chalk and Smith, 1983; Ussiri and Lal, 2013). This is the reason why studies focused on microbial sources in soils. Microbial processes in soil are the main source of $\mathrm{N}_{2} \mathrm{O}$ from soils, which are enhanced by high nitrogen fertilization and depend on soil conditions ( $\mathrm{pH}$, water content, oxygen $(\mathrm{O})$ availability, mineral nitrogen, $\mathrm{C}$ content and temperature) (Stehfest and Bouwman, 2006). Microbial sources of $\mathrm{N}_{2} \mathrm{O}$ differ in production pathways depending on ambient conditions and the organisms involved.

\section{Microbial $\mathrm{N}_{2} \mathrm{O}$ production pathways in soil}

Soil microorganisms produce $\mathrm{N}_{2} \mathrm{O}$ as intermediates or end products during different biochemical processes depending on the prevailing soil conditions. Autotrophic nitrification, nitrifier denitrification and denitrification represent the major pathways of $\mathrm{N}_{2} \mathrm{O}$ production, while codenitrification and heterotrophic nitrification are supposed to play a minor role in $\mathrm{N}_{2} \mathrm{O}$ production in soil (Figure 2) (Ussiri and Lal, 2013). 


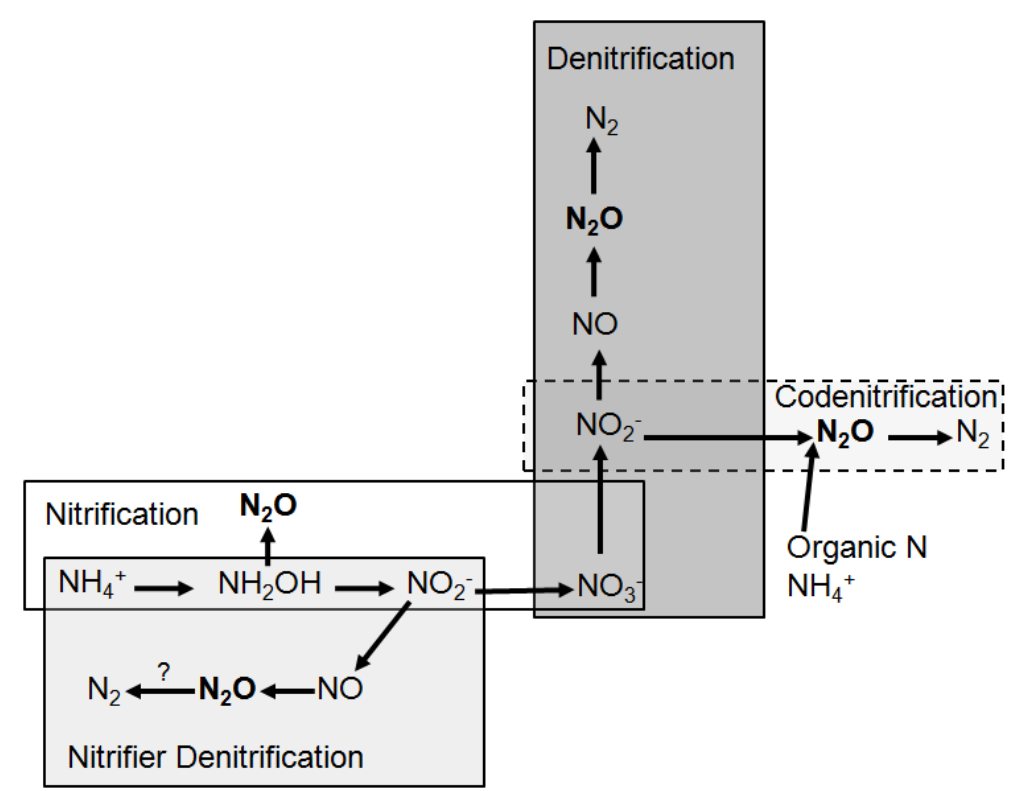

Figure 2: Microbial production pathways of nitrous oxide in soil by microorganisms (after Wrage et al. 2001, modified): aerobic nitrification, nitrifier denitrification and anaerobic denitrification are the main production pathways and codenitrification (dotted box) is a less important pathway producing $\mathrm{N}_{2} \mathrm{O}$ in soil.

Under aerobic soil conditions, nitrification is the predominant process of $\mathrm{N}_{2} \mathrm{O}$ production (Figure 2). Generally autotrophic bacteria are capable of ammonium $\left(\mathrm{NH}_{4}{ }^{+}\right)$oxidation with the end product nitrate $\left(\mathrm{NO}_{3}{ }^{-}\right)$and the intermediates hydroxylamine $\left(\mathrm{NH}_{2} \mathrm{OH}\right)$ and $\mathrm{NO}_{2}{ }^{-}$, while ammonium oxidation can evolve $\mathrm{N}_{2} \mathrm{O}$ as a by-product (autotrophic nitrification) (Baggs and Philippot, 2010). Heterotrophic nitrification might produce significant amounts of $\mathrm{N}_{2} \mathrm{O}$ only under certain environmental conditions (low $\mathrm{pH}$, high $\mathrm{O}_{2}$ amounts and organic material) (Anderson et al., 1993; Müller et al., 2014; Papen et al., 1989) and is more common among fungi than among bacteria, although some heterotrophic bacteria are capable of nitrification (Odu and Adeoye, 1970; Papen et al., 1989). Nitrifier denitrification has received more attention since its contribution to $\mathrm{N}_{2} \mathrm{O}$ production from soil was found some years ago (Kool et al., 2010). In this process, nitrifiers (autotrophic oxidizing bacteria) reduce $\mathrm{NO}_{2}{ }^{-}$to $\mathrm{N}_{2} \mathrm{O}$ or $\mathrm{N}_{2}$ (Wrage et al., 2001).

Beside nitrification, denitrification is known to significantly produce $\mathrm{N}_{2} \mathrm{O}$ emissions from soil, but under anaerobic or low oxygen conditions in soil, which can occur in aerated soils in anaerobic micro-sites, e.g., within soil aggregates (Sexstone et al., 1985). $\mathrm{NO}_{3}{ }^{-}$is stepwise reduced to $\mathrm{N}_{2}$, via $\mathrm{NO}_{2}{ }^{-}$and gaseous $\mathrm{NO}$ and $\mathrm{N}_{2} \mathrm{O}$ by heterotrophic organisms (Firestone and Davidson, 1989; Knowles, 1982; Zumft, 1997) (Figure 2). $\mathrm{N}_{2} \mathrm{O}$ can be emitted as an intermediate or is further reduced to $\mathrm{N}_{2} . \mathrm{NO}_{3}{ }^{-}$is abundant in soil, originating from cooccuring nitrification (nitrification-coupled-denitrification) as well as from fertilizer- $\mathrm{NO}_{3}{ }^{-}$ (fertilizer denitrification) (Ussiri and Lal, 2013). For a long time, heterotrophic bacteria were 
thought to be the only organisms capable of denitrification. However, fungi are also capable of denitrification and even some archaea were found to produce $\mathrm{N}_{2} \mathrm{O}$ under anaerobic conditions (Bollag and Tung, 1972; Hayatsu et al., 2008; Shoun et al., 1992). But archaeal denitrification and its product ratio is relatively unknown. First evidence for fungal denitrificartion was given by Bollag and Tung (1972) and ever since interest in this process increased and several years later Shoun et al. (1992) found that most fungi lack the enzyme $\mathrm{N}_{2} \mathrm{O}$ reductase (Nos), which was followed by several pure culture studies to get more information about the fungal pathway of denitrification (e.g. Kim et al., 2009; Shoun et al., 2012; Zhang and Shoun, 2008). Precise information about the contribution to $\mathrm{N}_{2} \mathrm{O}$ emissions from fungal denitrification as well as reliable methods to quantify fungal origin of $\mathrm{N}_{2} \mathrm{O}$ from a soil community are lacking so far.

Fungi not only produce $\mathrm{N}_{2} \mathrm{O}$ via denitrification, but are also able to produce a hybrid $\mathrm{N}_{2} \mathrm{O}$ from $\mathrm{NO}_{2}{ }^{-} \mathrm{N}$ and $\mathrm{N}$ from another source $\left(\mathrm{NH}_{4}{ }^{+}\right.$or organic $\mathrm{N}$ ) by codenitrification under anaerobic conditions (Spott and Stange, 2011). First evidence of codenitrification was observed by Tanimoto et al. (1992). The fungus Fusarium oxysporum produced $\mathrm{N}_{2} \mathrm{O}$ as the product of codenitrification (Tanimoto et al., 1992). Beyond that, Shoun et al. (1992) showed that Fusarium solani and Cylindrocarpon tonkinense formed $\mathrm{N}_{2}$ as end-product of codenitrification. Several years later, Spott et al. (2011) summarized that apart from the mentioned three fungal species at least 12 bacterial species and one archaeal species were found to be capable of codenitrification. However, information about the role of codenitrification in soil is very rare.

Studying $\mathrm{N}_{2} \mathrm{O}$ production under anaerobic conditions is of great importance to achieve more information about the contributing microorganisms. Several incubation studies indicated that fungi dominate $\mathrm{N}_{2} \mathrm{O}$ production from denitrification in soils (Blagodatskaya et al., 2010; Crenshaw et al., 2008; Laughlin and Stevens, 2002; Long et al., 2013; McLain and Martens, 2006). If dominance of fungal denitrification was common in soil, this would have to be considered in $\mathrm{N}_{2} \mathrm{O}$ flux modeling methods and in evaluating mitigation strategies.

\section{Enzymes involved in fungal denitrification}

Every reduction step of denitrification in microorganisms is catalyzed by specific enzymes (Ferguson, 1994; Knowles, 1982; Zumft, 1997) (Figure 3). Most information about these enzymatic steps was attained by studies with pure bacterial cultures (e.g. Allen and Niel, 1952; Sutka et al., 2004; Toyoda et al., 2005; Ye et al., 1994). As denitrification is a characteristic of anaerobic respiration, enzymes of denitrification compounds receive 
electrons (e) during the transport through the enzymes (Berks et al., 1995). Most enzymes of the anaerobic respiratory system of bacteria are located in the periplasm (Bothe et al., 2006; Ferguson, 1994; Zumft, 1997) and the resembling enzymes were found in the mitochondria of fungi (Kobayashi et al., 1996). In bacteria the $\mathrm{NO}_{3}{ }^{-}$reductase (Nar) was found soluble in the periplasm (Nap), but exists as well membrane-bound with its active site in the cytoplasm to catalyze the reduction of $\mathrm{NO}_{3}{ }^{-}$to $\mathrm{NO}_{2}{ }^{-}$. In the latter case, $\mathrm{NO}_{3}{ }^{-}$requires a transport through the membrane into the cytoplasm (Ferguson, 1994). Due to this transport, a concentration gradient between cytoplasm and periplasm, the returning transport of $\mathrm{NO}_{2}{ }^{-}$to the periplasm of the cell, and the on-going reduction is possible. All other enzymes $\left(\mathrm{NO}_{2}{ }^{-}\right.$reductase (Nir), $\mathrm{NO}$ reductase (Nor) and $\mathrm{N}_{2} \mathrm{O}$ reductase (Nos)) are located inside the periplasm of the bacterial cells. Although the locations of the enzymes were found to be similar in bacteria, pure culture studies revealed different enzyme types for Nir, heme-cd1 and copper Nir, as well as for Nor, cNor, qNor or qCuNor, depending on the species. Enzymes involved in fungal denitrification were found to be similar to bacterial enzymes, except for Nor, which was the only enzyme differing between bacteria and fungi (P450nor) (de Vries et al., 2007; Kim et al., 2009; van Spanning et al., 2007). Fungal P450nor are similar to bacterial cytochrome P450 and probably both types are evolutionarily related (van Spanning et al., 2007; Zumft, 1997). As mentioned previously Nar and Nir of Fusarium oxysporum were found to be located in the mitochondria and this location enables fungi to receive $\mathrm{e}^{-}$from sources of energy (e.g., succinate, formate, malate or pyruvate). Regarding formate as supplier of $\mathrm{e}^{-}$, fungal Nar might be more equal to $\mathrm{NO}_{3}{ }^{-}$respiration by $E$. coli than to that of bacterial Nar (Bothe et al., 2006). Until now, there has been no study that could prove the existence of $\mathrm{N}_{2} \mathrm{O}$ reductase (Nos) existing in fungi (Zumft and Körner, 2007), although some fungal pure cultures produced minimal amounts of $\mathrm{N}_{2}$ during denitrification or codenitrification (Shoun et al., 1992). The lack of Nos enables fungi to potentially release much more $\mathrm{N}_{2} \mathrm{O}$ compared to bacteria assuming both groups have the same production rates and thus this observation gave hints of a potentially great contribution of fungi to $\mathrm{N}_{2} \mathrm{O}$ emissions from soil (Sutka et al., 2008). 


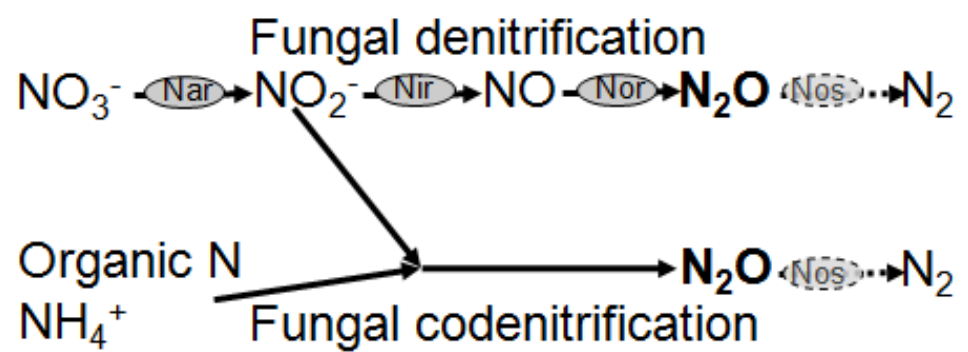

Figure 3: Fungal pathways of denitrification and codenitrification producing nitrous oxide $\left(\mathrm{N}_{2} \mathrm{O}\right)$ in soils under anaerobic conditions and the associated enzymes. Pure culture studies revealed that most fungi lack Nos (marked in light gray) (Shoun et al., 1992). For further information see text.

\section{Isotopic analysis of $\mathrm{N}_{2} \mathrm{O}$ to distinguish between sources of $\mathrm{N}_{2} \mathrm{O}$ from denitrification}

Analysis of stable isotopes of $\mathrm{N}_{2} \mathrm{O}$ turned out to be useful in isotope tracing as well as natural abundance studies to understand the contribution of different $\mathrm{N}_{2} \mathrm{O}$ processes and sources. $\mathrm{N}_{2} \mathrm{O}$ can be used for isotope analysis, because it contains two elements ( $\mathrm{N}$ and $\mathrm{O}$ ) with several stable isotopes. Under natural condition, isotopes of an element vary in the number of neutrons and thus in the mass (Fry, 2006). For N, the natural abundance of the low mass isotope ${ }^{14} \mathrm{~N}$ is $99.64 \%$, whereas the high mass isotope ${ }^{15} \mathrm{~N}$ is less abundant (0.36\%) (Fry, 2006). For $\mathrm{O}$, three stable isotopes exist, differing in the natural abundance: ${ }^{16} \mathrm{O}(99.76 \%),{ }^{17} \mathrm{O}$ (0.04\%) and ${ }^{18} \mathrm{O}(0.20 \%)$ (Fry, 2006).

Under natural conditions, isotope studies take advantage of the natural isotopic fractionation during reaction steps for lower mass isotopes $\left({ }^{14} \mathrm{~N}\right.$ or $\left.{ }^{16} \mathrm{O}\right)$ (Fry, 2006). For example, the more abundant ${ }^{14} \mathrm{~N}^{14} \mathrm{~N}^{16} \mathrm{O}$ molecule with lower mass shows higher reaction rates and less bonding force compared to the less abundant ${ }^{14} \mathrm{~N}^{15} \mathrm{~N}^{16} \mathrm{O},{ }^{15} \mathrm{~N}^{14} \mathrm{~N}^{16} \mathrm{O}$ or ${ }^{14} \mathrm{~N}^{14} \mathrm{~N}^{18} \mathrm{O}$ molecules with higher mass. Thus, $\mathrm{N}_{2} \mathrm{O}$ from nitrification is generally composed of isotopes with lower mass relative to the electron acceptor compared to $\mathrm{N}_{2} \mathrm{O}$ from denitrification, due to (i) different fractionation effects of $\mathrm{N}_{2} \mathrm{O}$ production, probably because of different enzymatic steps involved in both processes (Toyoda et al., 2002), (ii) the reduction step of $\mathrm{N}_{2} \mathrm{O}$ to $\mathrm{N}_{2}$ during denitrification results in $\mathrm{N}_{2} \mathrm{O}$ relatively enriched in ${ }^{18} \mathrm{O}$ and ${ }^{15} \mathrm{~N}$ compared to denitrification without $\mathrm{N}_{2} \mathrm{O}$ reduction step (Popp et al., 2002) and (iii) the intramolecular isotopic fractionation, which prefers cleavage of ${ }^{14} \mathrm{NO}$ compared to ${ }^{15} \mathrm{NO}$ (Baggs, 2008; Toyoda et al., 2005; Yoshida and Toyoda, 2000). The ratios of ${ }^{15} \mathrm{~N} /{ }^{14} \mathrm{~N}$ or ${ }^{18} \mathrm{O} /{ }^{16} \mathrm{O}$ in molecules of a sample $\left(R_{\text {sample }}\right)$ can be compared to the corresponding ratios of an internationally accepted standard $\left(R_{\text {standard }}\right)$ and expressed as delta-values $(\delta)$ in permil (\%o) (Fry, 2006).

$\delta=\frac{R_{\text {Sample }}-R_{\text {Standard }}}{R_{\text {Standard }}} \cdot 1000$ 
Several studies could show specific isotopic values of $\mathrm{N}_{2} \mathrm{O}$ for different production pathways (Table 1). Molecules that differ in the isotopic composition are called "isotopologues", while molecules that contain the same isotopes (and thus have the same mass), but differ in the position of the tracing isotopes within the molecule are termed "isotopomers" (Ostrom and Ostrom, 2011). Regarding the intramolecular distribution of ${ }^{15} \mathrm{~N}$ in $\mathrm{N}_{2} \mathrm{O}$, there are two possibilities for its position in the asymmetric and linear molecule: the central alpha $(\alpha)$ position and the peripheral beta $(\beta)$ position (Brenninkmeijer and Röckmann, 1999; Toyoda and Yoshida, 1999). This distribution was first analyzed and independently published by two groups in the same year (Brenninkmeijer and Röckmann, 1999; Toyoda and Yoshida, 1999). The ${ }^{15} \mathrm{~N}$ distribution in $\mathrm{N}_{2} \mathrm{O}$ serves to calculate the ${ }^{15} \mathrm{~N}$ site preference of $\mathrm{N}_{2} \mathrm{O}$ (SP) (Toyoda and Yoshida, 1999):

${ }^{15} \mathrm{~N}-\mathrm{SP}=\delta^{15} \mathrm{~N}^{\alpha}-\delta^{15} \mathrm{~N}^{\beta}$

Analyzing the isotopic composition of $\mathrm{N}_{2} \mathrm{O}$, including SP, revealed that different production pathways of $\mathrm{N}_{2} \mathrm{O}$ differ in isotopologue values (Table 1). Many pure culture studies focusing on $\mathrm{N}_{2} \mathrm{O}$ production pathways showed that $\mathrm{N}_{2} \mathrm{O}$ from nitrification is characterized by a SP of $\mathrm{N}_{2} \mathrm{O}$ of 33 \% (Sutka et al., 2006), whereas $\mathrm{N}_{2} \mathrm{O}$ from bacterial denitrification showed much lower SP values between -11 and 0 \%o (Frame and Casciotti, 2010; Sutka et al., 2006). Cultivating fungi showed that two denitrifying species produced $\mathrm{N}_{2} \mathrm{O}$ with substantially higher SP values of 37 \% compared to several bacteria (Frame and Casciotti, 2010; Sutka et al., 2008; Sutka et al., 2006). Thus, under standard and designed laboratory conditions, fungal and bacterial contribution to $\mathrm{N}_{2} \mathrm{O}$ produced by denitrification might be distinguishable. Under natural soil conditions, however, SP of $\mathrm{N}_{2} \mathrm{O}$ produced by fungi might overlap with SP of $\mathrm{N}_{2} \mathrm{O}$ from nitrification (Table 1) (Ostrom and Ostrom, 2011; Sutka et al., 2006). Additionally, isotopologues of $\mathrm{N}_{2} \mathrm{O}$ produced during denitrification in soil are altered by $\mathrm{N}_{2} \mathrm{O}$ reduction to $\mathrm{N}_{2}$. The residual $\mathrm{N}_{2} \mathrm{O}$ contains relatively more isotopes with high mass $\left({ }^{15} \mathrm{~N}\right.$ and $\left.{ }^{18} \mathrm{O}\right)$ compared to $\mathrm{N}_{2} \mathrm{O}$ that is not further reduced by microorganisms. However, despite these limitations, the specific isotopic characteristic of $\mathrm{N}_{2} \mathrm{O}$ from different sources (e.g., nitrification and denitrification) and different microorganisms (e.g., fungi and bacteria) might be a promising tool to obtain necessary information for developing new methods and strategies for agricultural practices to reduce the emissions of $\mathrm{N}_{2} \mathrm{O}$. 
Table 1: Overview about ranges of $\delta^{15} \mathrm{~N}_{\text {bulk }}, \delta^{18} \mathrm{O}$ and SP of $\mathrm{N}_{2} \mathrm{O}$ [\%o] produced during different processes by pure cultures or soil incubations with constrained conditions for nitrification or denitrification from literature.

\begin{tabular}{|c|c|c|c|c|}
\hline Production process & $\delta^{18} \mathrm{O}[\%$ ] & $\delta^{15} \mathbf{N}[\%]$ & SP [\%o] & Source \\
\hline \multirow[t]{3}{*}{ Nitrification } & +22 to +61 & -3 to 3 & +25 to +40 & $\mathrm{a}$ \\
\hline & +22 to +25 & -47 to -46 & +28 to +37 & $\mathrm{~b}$ \\
\hline & +33 to +35 & +6 to +10 & +29 to +32 & C \\
\hline \multirow{3}{*}{$\begin{array}{l}\text { Nitrifier denitrification } \\
\text { Codenitrification } \\
\text { Fungal denitrification }\end{array}$} & +7 to +12 & -54 to -23 & -14 to +9 & $\mathrm{~d}$ \\
\hline & \multicolumn{4}{|c|}{ not investigated yet } \\
\hline & +30 to +39 & -3 to -20 & +23 to +40 & e \\
\hline Bacterial denitrification & +7 to +47 & -38 to -8 & -9 to -1 & $\mathrm{f}$ \\
\hline Nitrification $_{\text {soil }}$ & +8 to +31 & -58 to +9 & -7 to +36 & g \\
\hline Denitrification $_{\text {soil (NO3-N2) }}$ & +28 to +52 & -38 to -6 & +3 to +26 & $\mathrm{~h}$ \\
\hline Denitrification $_{\text {soil (NO3-N2O) }}$ & +4 to +23 & -51 to -27 & -4 to +18 & i \\
\hline
\end{tabular}

${ }^{a}$ Sutka et al. (2004) and Sutka et al. (2006): Methylococcus capsulatus and Nitrosomonas europaea $\left(\mathrm{NH}_{2} \mathrm{OH}\right)$

${ }^{\mathrm{b}}$ Sutka et al. (2006): Nitrosomonas europaea $\left(\mathrm{NH}_{4}{ }^{+}\right)$

${ }^{c}$ Santoro et al. (2011): ammonia oxidizing archaea (AOA)

${ }^{\mathrm{d}}$ Frame and Casciotti (2010): Nitrosomonas marina; Sutka et al. (2004): Nitrosomonas europaea, Sutka et al. (2006): Nitrosospira multiformis

${ }^{\mathrm{e}}$ Sutka et al. (2008): Fusarium oxysporum, Cylindrocarpon tonkinense $\left(\mathrm{NO}_{2}{ }^{-}\right)$

${ }^{\mathrm{f}}$ Toyoda et al. (2005): Pseudomonas fluorescens and Paracoccus denitrificans $\left(\mathrm{NO}_{2}{ }^{-}\right)$, note: without values of Pseudomonas fluorescence; Sutka et al. (2006): Pseudomonas chlororaphis, Pseudomonas aureofaciens

${ }^{g}$ Well et al. (2006) 55\% WFPS, (Well et al., 2008)

${ }^{\mathrm{h}}$ Well et al. (2006) 75 and 85\% WFPS; Snider et al. (2009) $\delta^{15} \mathrm{~N}$ values only; Perez et al. (2006) and Park et al. (2011)

${ }^{\mathrm{i}}$ Well and Flessa (2009); Lewicka-Szczebak et al. (2014) with $\mathrm{C}_{2} \mathrm{H}_{2}$ to inhibit the $\mathrm{N}_{2} \mathrm{O}$ reduction; Park et al. (2011); Perez et al. (2006) SP only

Isotope tracer experiments are useful to quantify the contribution from different sources of substrates for $\mathrm{N}_{2} \mathrm{O}$ production. In such experiments, substrates that are enriched in ${ }^{15} \mathrm{~N}$ (commonly ${ }^{15} \mathrm{~N}$ labeled $\mathrm{NH}_{4}{ }^{+}$or $\mathrm{NO}_{3}{ }^{-}$) or ${ }^{18} \mathrm{O}$ (commonly ${ }^{18} \mathrm{O}$ labeled $\mathrm{NO}_{3}{ }^{-}$or water) only or in both isotopes, can be applied to trace their fate by analyzing isotopic enrichment of

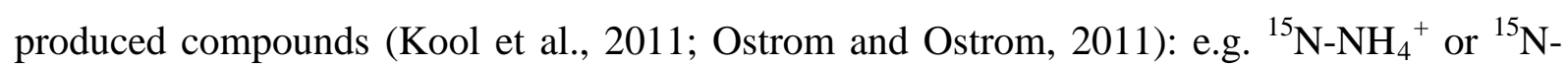
$\mathrm{NO}_{3}{ }^{-}$application can be used to distinguish between $\mathrm{N}_{2} \mathrm{O}$ fluxes from these sources by ${ }^{15} \mathrm{~N}$ $\mathrm{N}_{2} \mathrm{O}$ analysis (Baggs, 2008). Tracing ${ }^{15} \mathrm{~N}^{-\mathrm{NO}_{3}}{ }^{-}$is also suitable for quantifying $\mathrm{N}_{2} \mathrm{O}$ formation during codenitrification under controlled anaerobic conditions as $\mathrm{N}_{2} \mathrm{O}$ produced is a hybrid molecule from $\mathrm{NO}_{3}{ }^{-}$and another $\mathrm{N}$ source (Laughlin and Stevens, 2002; Spott et al., 2011). When ${ }^{15} \mathrm{~N}-\mathrm{NO}_{3}$ is applied $\mathrm{N}_{2} \mathrm{O}$ produced by denitrification is highly enriched in ${ }^{15} \mathrm{~N}$, because both $\mathrm{N}$ atoms are obtained from $\mathrm{NO}_{3}{ }^{-}$, whereas $\mathrm{N}_{2} \mathrm{O}$ produced by codenitrification is relatively less enriched in ${ }^{15} \mathrm{~N}$, because the hybrid $\mathrm{N}_{2} \mathrm{O}$ is formed from an $\mathrm{N}$ of $\mathrm{NO}_{3}{ }^{-}$and of another unlabeled N compound (Shoun et al., 1992; Spott et al., 2011). A combined labeling 
approach of substrates $\left({ }^{15} \mathrm{~N}-\mathrm{NO}_{3}\right.$ and/or ${ }^{15} \mathrm{~N}-\mathrm{NH}_{4}$ and ${ }^{18} \mathrm{O}$-water) was proposed by Wrage et al. (2005) for the first time to (i) differentiate between denitrification and nitrification by ${ }^{15} \mathrm{~N}$ application and to (ii) analyze the origin of $\mathrm{O}$ in $\mathrm{N}_{2} \mathrm{O}$ by ${ }^{18} \mathrm{O}$ application: the $\mathrm{O}$ of $\mathrm{N}_{2} \mathrm{O}$ from nitrification originates from atmospheric $\mathrm{O}_{2}$, whereas $\mathrm{O}$ of $\mathrm{N}_{2} \mathrm{O}$ during nitrifier denitrification originates from water, which can be observed in $\mathrm{N}_{2} \mathrm{O}$ produced from ${ }^{18} \mathrm{O}$-labeled water and can thus be distinguished from nitrification.

Besides the differentiation between $\mathrm{N}$ sources of $\mathrm{N}_{2} \mathrm{O}$, tracer experiments with ${ }^{18} \mathrm{O}$-labeling of water have been used to quantify $\mathrm{O}$ exchange during denitrification in bacteria (e.g. Aerssens et al., 1986; Kool et al., 2011). In case this $\mathrm{O}$ exchange is almost complete, the ${ }^{18} \mathrm{O}$ signature of $\mathrm{N}_{2} \mathrm{O}$ would be almost unaffected by isotopic fractionation during denitrification, but would be dependent on the $\delta^{18} \mathrm{O}$ of soil water and the isotope effect during $\mathrm{O}$ exchange. Until now, $\mathrm{O}$ exchange during denitrification was found in several bacteria and it varied between 4 and $100 \%$, while its occurrence is completely uninvestigated for fungi (Aerssens et al., 1986; Garber and Hollocher, 1982; Kool et al., 2007; Ye et al., 1991).

\section{Modified substrate induced respiration with selective inhibition (SIRIN) to distinguish between sources of $\mathrm{N}_{2} \mathrm{O}$ from denitrification}

Until now no reliable method to differentiate $\mathrm{N}_{2} \mathrm{O}$ produced during denitrification by bacteria or fungi is available for soil incubation experiments. Several studies used a modification of the substrate induced respiration with selective inhibition (SIRIN) (Anderson and Domsch, 1973) to distinguish between $\mathrm{N}_{2} \mathrm{O}$ produced during denitrification by bacteria or fungi (Blagodatskaya et al., 2010; Laughlin and Stevens, 2002; Long et al., 2013; McLain and Martens, 2006). This method is based on the application of selective antibiotics, that inhibit the specific protein biosynthesis of either fungi or bacteria (Anderson and Domsch, 1973). Analyzing the evolved $\mathrm{CO}_{2}$ gave information about contribution of bacteria or fungi on $\mathrm{CO}_{2}$ respiration (Anderson and Domsch, 1973). Laughlin and Stevens (2002) modified this approach and first published results of soil incubation experiments where $\mathrm{N}_{2} \mathrm{O}$ from denitrification produced by bacteria or fungi was determined. They found that inhibition of bacterial growth resulted in $23 \%$ reduced $\mathrm{N}_{2} \mathrm{O}$ production compared to $\mathrm{N}_{2} \mathrm{O}$ produced without growth inhibition, whereas with fungal growth inhibition $\mathrm{N}_{2} \mathrm{O}$ production decreased about 89\% (Laughlin and Stevens, 2002). Similar growth inhibitor effects on $\mathrm{N}_{2} \mathrm{O}$ production from denitrification were observed in the following years by other groups (Blagodatskaya et al., 2010; Crenshaw et al., 2008; Long et al., 2013; McLain and Martens, 2006), confirming the assumption that fungi might play a dominant role in producing $\mathrm{N}_{2} \mathrm{O}$ during denitrification 
under natural conditions. Until now, the validity of these results was not tested by independent approaches. Moreover, in view of the need to establish anaerobic growth conditions in the laboratory, it is not clear to which extent responses to inhibitors represent fungal and bacterial $\mathrm{N}_{2} \mathrm{O}$ production under normal soil conditions. A comparison between the SIRIN approach and isotopologue values of $\mathrm{N}_{2} \mathrm{O}$ emissions as indicators of fungal denitrification has not been conducted so far, but would be a useful step in the study of fungal denitrification.

\section{$\underline{\text { Objectives }}$}

The present study aimed at enhancing the knowledge about $\mathrm{N}_{2} \mathrm{O}$ produced during fungal denitrification. As explained earlier, previous studies indicated that fungal contribution to $\mathrm{N}_{2} \mathrm{O}$ emissions from denitrification has to be taken into account when distinguishing between $\mathrm{N}_{2} \mathrm{O}$ sources and developing strategies to mitigate $\mathrm{N}_{2} \mathrm{O}$ fluxes from soils. Therefore extended knowledge about fungal denitrification is absolutely essential. Hence, the objectives were:

1. to analyze the $\mathrm{O}$ exchange between denitrification intermediates and water during $\mathrm{N}_{2} \mathrm{O}$ production by fungal denitrification

2. to verify high SP values of $\mathrm{N}_{2} \mathrm{O}$ from fungal denitrification reported in the literature for four additional fungal species,

3. to investigate if fungi existing in a soil community produce $\mathrm{N}_{2} \mathrm{O}$ isotopologue values comparable to values known from pure fungal cultures, and

4. to determine fungal $\mathrm{N}_{2} \mathrm{O}$ production in agricultural soils comparatively using SIRIN and the isotopologue approach.

\section{Experimental concept}

\section{Fungal pure cultures}

For pure culture experiments six different fungal strains were incubated under denitrifying conditions to measure the isotopic composition of $\mathrm{N}_{2} \mathrm{O}$ produced and to determine the $\mathrm{O}$ exchange between denitrification intermediates and water. Stem cultures were ordered from the Japan Collection of Microorganisms (JCM, Saitama, Japan) and Nite Biological Research Center (NBRC, Chiba, Japan). The three species from JCM were Chaetomium funicola, Fusarium oxysporum and Trichoderma hamatum (Catalogue numbers JCM 22733, JCM 
11502 and JCM 1875, respectively) and the three species from NBRC were Cylindrocarpon lichenicola, Fusarium solani fsp. pisi and Fusarium decemcellulare (catalogue numbers NBRC 30561, NBRC 9425 and NBRC 31657, respectively). These fungal species typically occur in soil (Domsch et al., 1980) and are known from previous pure culture studies by Shoun et al. (1992) to be capable of denitrification.

\section{Soil incubations}

Agricultural soils from three different locations in Germany (Braunschweig, Wennebostel, and Reinshof) were used for anaerobic incubations. The soil texture and chemical properties of the three soils differed. Hence, the impact of different soil types on microbial community and the isotopologues of $\mathrm{N}_{2} \mathrm{O}$ produced could be investigated. Isotopologue analysis of $\mathrm{N}_{2} \mathrm{O}$ fluxes was combined with a modification of SIRIN to get a best estimate of the bacterial and fungal contribution to total soil denitrification and to compare both approaches, and thus to evaluate their consistency. An important question of the methodical evaluation was, if the distinct isotopologue values of $\mathrm{N}_{2} \mathrm{O}$ produced by pure cultures are found as well in $\mathrm{N}_{2} \mathrm{O}$ produced by a microbial soil community with selective growth inhibition of bacteria or fungi.

\section{$\underline{\text { References }}$}

Aerssens, E., Tiedje, J.M., Averill, B.A., 1986. Isotope Labeling Studies on the Mechanisms of N-bond Formation in Denitrification. Journal of Biological Chemistry 261, 96529656.

Allen, M.B., Niel, C.B.V., 1952. Experiments on bacterial denitrification. Journal of Bacteriology 64, 397-412.

Anderson, I.C., Poth, M., Homstead, J., Burdige, D., 1993. A comparison of $\mathrm{NO}$ and $\mathrm{N}_{2} \mathrm{O}$ production by the autotrophic nitrifier Nitrosomas europaea and the heterotrophic nitrifier Alcaligenes faecalis. Applied and Environmental Microbiology 59, 35253533.

Anderson, J.P., Domsch, K.H., 1973. Quantification of bacterial and fungal contributions to soil respiration. Archiv Fur Mikrobiologie 93, 113-127.

Baggs, E., Philippot, L., 2010. Microbial Terrestrial Pathways to Nitrous Oxide, In: Smith, K. (Ed.), Nitrous oxide and climate change. Eathscan Ltd, London, UK, p. 232.

Baggs, E.M., 2008. A review of stable isotope techniques for $\mathrm{N}_{2} \mathrm{O}$ source partitioning in soils: recent progress, remaining challenges and future considerations. Rapid Communications in Mass Spectrometry 22, 1664-1672.

Berks, B.C., Ferguson, S.J., Moir, J.W.B., Richardson, D.J., 1995. Enzymes and associated electron transport systems that catalyse the respiratory reduction of nitrogen oxides and oxyanions. Biochimica Et Biophysica Acta-Bioenergetics 1232, 97-173.

Blagodatskaya, E., Dannenmann, M., Gasche, R., Butterbach-Bahl, K., 2010. Microclimate and forest management alter fungal-to-bacterial ratio and $\mathrm{N}_{2} \mathrm{O}$-emission during rewetting in the forest floor and mineral soil of mountainous beech forests. Biogeochemistry 97, 55-70. 
Bollag, J.M., Tung, G., 1972. Nitrous oxide release by soil fungi. Soil Biology and Biochemistry 4, 271-276.

Bothe, H., Ferguson, S., Newton, W.E., 2006. Biology of the Nitrogen Cycle. Elsevier, 452 pp.

Brenninkmeijer, C.A.M., Röckmann, T., 1999. Mass spectrometry of the intramolecular nitrogen isotope distribution of environmental nitrous oxide using fragment-ion analysis. Rapid Communications in Mass Spectrometry 13, 2028-2033.

Chalk, P.M., Smith, C.J., 1983. Chemodenitrification. Gaseous loss of nitrogen from plantsoil systems, 65-89.

Crenshaw, C.L., Lauber, C., Sinsabaugh, R.L., Stavely, L.K., 2008. Fungal control of nitrous oxide production in semiarid grassland. Biogeochemistry 87, 17-27.

Crutzen, P.J., 1970. The influence of nitrogen oxides on the atmospheric ozone content. Quarterly Journal of the Royal Meteorological Society 96, 320-325.

Crutzen, P.J., 1972. Supersonic transports a threat to the earths ozone shield. Ambio 1, 41-51.

Crutzen, P.J., Ehhalt, D.H., 1977. Effects of nitrogen fertilizers and combustion on the stratosphereic onzone layer. Ambio 6, 112-117.

de Vries, S., Suharti, Pouvreau, L.A.M., 2007. Chapter 4 - Nitric Oxide Reductase: Structural Variations and Catalytic Mechanism, In: Bothe, H., Ferguson, S.J., Newton, W.E. (Eds.), Biology of the Nitrogen Cycle. Elsevier, Amsterdam, pp. 57-66.

Del Grosso, S.J., Wirth, T., Ogle, S.M., Parton, W.J., 2008. Estimating Agricultural Nitrous Oxide Emissions. Eos, Transactions American Geophysical Union 89, 529-529.

Domsch, K.H., Gams, W., Anderson, T.H., 1980. Compendium of soil fungi. Volumes 1 and 2. Academic Press Ltd., London, UK, vii + 859 pp.

Ferguson, S.J., 1994. Denitrification and its control. Antonie Van Leeuwenhoek International Journal of General and Molecular Microbiology 66, 89-110.

Firestone, M.K., Davidson, E.A., 1989. Microbiological basis of $\mathrm{NO}$ and $\mathrm{N}_{2} \mathrm{O}$ production and consumption in soil, In: Andreae, M.O., Schimel, D.S. (Eds.). Wiley, New York, NY, pp. 7-21.

Frame, C.H., Casciotti, K.L., 2010. Biogeochemical controls and isotopic signatures of nitrous oxide production by a marine ammonia-oxidizing bacterium. Biogeosciences 7, 2695-2709.

Fry, B., 2006. Stable Isotope Ecology. Springer Science+Business Media, LLC, New York, NY, USA.

Garber, E.A., Hollocher, T.C., 1982. ${ }^{15} \mathrm{~N},{ }^{18} \mathrm{O}$ tracer studies on the activation of nitrite by denitrifying bacteria. Nitrite/water-oxygen exchange and nitrosation reactions as indicators of electrophilic catalysis. Journal of Biological Chemistry 257, 8091-8097.

Hayatsu, M., Tago, K., Saito, M., 2008. Various players in the nitrogen cycle: Diversity and functions of the microorganisms involved in nitrification and denitrification. Soil Science \& Plant Nutrition 54, 33-45.

IPCC, 2013. Climate Change 2013: The Physical Science Basis. Contribution of Working Group I to the Fifth Assessment Report of the Intergovernmental Panel on Climate Change, In: Stocker, T.F., Qin, D., Plattner, G.-K., Tignor, M., Allen, S.K., Boschung, J., Nauels, A., Xia, Y., Bex, V., Midgley, P.M. (Eds.), Cambridge, United Kingdom and New York, NY, USA, p. 1535 pp.

Kim, S.W., Fushinobu, S., Zhou, S.M., Wakagi, T., Shoun, H., 2009. Eukaryotic nirK Genes Encoding Copper-Containing Nitrite Reductase: Originating from the Protomitochondrion? Applied and Environmental Microbiology 75, 2652-2658.

Knowles, R., 1982. Denitrification. Microbiological Reviews 46, 43-70.

Kobayashi, M., Matsuo, Y., Takimoto, A., Suzuki, S., Maruo, F., Shoun, H., 1996. Denitrification, a novel type of respiratory metabolism in fungal mitochondrion. Journal of Biological Chemistry 271, 16263-16267. 
Kool, D.M., Van Groenigen, J.W., Wrage, N., 2011. Source dertermination of Nitrous Oxide based on Nitrogen and Oxygen Isotopes tracing: Dealing with Oxygen Exchange, In: Klotz, M.G., Stein, L.Y. (Eds.), Methods in Enzymology, Vol 46: Research on Nitrification and Related Processes, Pt B, pp. 139-160.

Kool, D.M., Wrage, N., Oenema, O., Dolfing, J., Van Groenigen, J.W., 2007. Oxygen exchange between (de)nitrification intermediates and $\mathrm{H}_{2} \mathrm{O}$ and its implications for source determination of $\mathrm{NO}_{3}{ }^{-}$and $\mathrm{N}_{2} \mathrm{O}$ : a review. Rapid Communications in Mass Spectrometry 21, 3569-3578.

Kool, D.M., Wrage, N., Zechmeister-Boltenstern, S., Pfeffer, M., Brus, D., Oenema, O., Van Groenigen, J.W., 2010. Nitrifier denitrification can be a source of $\mathrm{N}_{2} \mathrm{O}$ from soil: a revised approach to the dual-isotope labelling method. European Journal of Soil Science 61, 759-772.

Laughlin, R.J., Stevens, R.J., 2002. Evidence for Fungal Dominance of Denitrification and Codenitrification in a Grassland Soil. Soil Science Society of America Journal 66, 1540-1548.

Lewicka-Szczebak, D., Well, R., Köster, J.R., Fuß, R., Senbayram, M., Dittert, K., Flessa, H., 2014. Experimental determinations of isotopic fractionation factors associated with $\mathrm{N}_{2} \mathrm{O}$ production and reduction during denitrification. Geochimica et Cosmochimica Acta, accepted.

Long, A., Heitman, J., Tobias, C., Philips, R., Song, B., 2013. Co-Occurring Anammox, Denitrification, and Codenitrification in Agricultural Soils. Applied and Environmental Microbiology 79, 168-176.

McLain, J.E.T., Martens, D.A., 2006. $\mathrm{N}_{2} \mathrm{O}$ production by heterotrophic $\mathrm{N}$ transformations in a semiarid soil. Applied Soil Ecology 32, 253-263.

Müller, C., Laughlin, R.J., Spott, O., Rütting, T., 2014. Quantification of $\mathrm{N}_{2} \mathrm{O}$ emission pathways via a ${ }^{15} \mathrm{~N}$ tracing model. Soil Biology and Biochemistry 72, 44-54.

Odu, C.T.I., Adeoye, K.B., 1970. Heterotrophic nitrification in soils - a preliminary investigation. Soil Biology and Biochemistry 2, 41-45.

Ostrom, N., Ostrom, P., 2011. The Isotopomers of Nitrous Oxide: Analytical Considerations and Application to Resolution of Microbial Production Pathways, In: Baskaran, M. (Ed.), Handbook of Environmental Isotope Geochemistry. Springer Berlin Heidelberg, pp. 453-476.

Papen, H., Vonberg, R., Hinkel, I., Thoene, B., Rennenberg, H., 1989. Heterotrophic nitrification by Alcaligenes faecalis - $\mathrm{NO}_{2}^{-}, \mathrm{NO}_{3}{ }^{-}, \mathrm{N}_{2} \mathrm{O}$, and $\mathrm{NO}$ production in exponentially growing cultures. Applied and Environmental Microbiology 55, 20682072.

Park, S., Pérez, T., Boering, K.A., Trumbore, S.E., Gil, J., Marquina, S., Tyler, S.C., 2011. Can $\mathrm{N}_{2} \mathrm{O}$ stable isotopes and isotopomers be useful tools to characterize sources and microbial pathways of $\mathrm{N}_{2} \mathrm{O}$ production and consumption in tropical soils? Global Biogeochemical Cycles 25, GB1001.

Perez, T., Garcia-Montiel, D., Trumbore, S., Tyler, S., De Camargo, P., Moreira, M., Piccolo, M., Cerri, C., 2006. Nitrous oxide nitrification and denitrification ${ }^{15} \mathrm{~N}$ enrichment factors from Amazon forest soils. Ecological Applications 16, 2153-2167.

Popp, B.N., Westley, M.B., Toyoda, S., Miwa, T., Dore, J.E., Yoshida, N., Rust, T.M., Sansone, F.J., Russ, M.E., Ostrom, N.E., Ostrom, P.H., 2002. Nitrogen and oxygen isotopomeric constraints on the origins and sea-to-air flux of $\mathrm{N}_{2} \mathrm{O}$ in the oligotrophic subtropical North Pacific gyre. Global Biogeochemical Cycles 16.

Santoro, A.E., Buchwald, C., McIlvin, M.R., Casciotti, K.L., 2011. Isotopic Signature of $\mathrm{N}_{2} \mathrm{O}$ Produced by Marine Ammonia-Oxidizing Archaea. Science 333, 1282-1285. 
Sexstone, A.J., Revsbech, N.P., Parkin, T.B., Tiedje, J.M., 1985. Direct measurement of oxygen profiles and denitrification rates in soil aggregates. Soil Science Society of America Journal 49, 645-651.

Shoun, H., Fushinobu, S., Jiang, L., Kim, S.W., Wakagi, T., 2012. Fungal denitrification and nitric oxide reductase cytochrome P450nor. Philosophical Transactions of the Royal Society B-Biological Sciences 367, 1186-1194.

Shoun, H., Kim, D.-H., Uchiyama, H., Sugiyama, J., 1992. Denitrification by fungi. FEMS Microbiology Letters 94, 277-281.

Snider, D.M., Schiff, S.L., Spoelstra, J., 2009. ${ }^{15} \mathrm{~N} /{ }^{14} \mathrm{~N}$ and ${ }^{18} \mathrm{O} /{ }^{16} \mathrm{O}$ stable isotope ratios of nitrous oxide produced during denitrification in temperate forest soils. Geochimica et Cosmochimica Acta 73, 877-888.

Spott, O., Russow, R., Stange, C.F., 2011. Formation of hybrid $\mathrm{N}_{2} \mathrm{O}$ and hybrid $\mathrm{N}_{2}$ due to codenitrification: First review of a barely considered process of microbially mediated N-nitrosation. Soil Biology \& Biochemistry 43, 1995-2011.

Spott, O., Stange, F.C., 2011. Formation of hybrid $\mathrm{N}_{2} \mathrm{O}$ in a suspended soil due to codenitrification of $\mathrm{NH}_{2} \mathrm{OH}$. Journal of Plant Nutrition and Soil Science, n/a-n/a.

Stehfest, E., Bouwman, L., 2006. N2O and NO emission from agricultural fields and soils under natural vegetation: summarizing available measurement data and modeling of global annual emissions. Nutrient Cycling in Agroecosystems 74, 207-228.

Sutka, R.L., Adams, G.C., Ostrom, N.E., Ostrom, P.H., 2008. Isotopologue fractionation during $\mathrm{N}_{2} \mathrm{O}$ production by fungal denitrification. Rapid Communications in Mass Spectrometry 22, 3989-3996.

Sutka, R.L., Ostrom, N.E., Ostrom, P.H., Breznak, J.A., Gandhi, H., Pitt, A.J., Li, F., 2006. Distinguishing Nitrous Oxide Production from Nitrification and Denitrification on the Basis of Isotopomer Abundances. Applied and Environmental Microbiology 72, 638644.

Sutka, R.L., Ostrom, N.E., Ostrom, P.H., Gandhi, H., Breznak, J.A., 2004. Nitrogen isotopomer site preference of $\mathrm{N}_{2} \mathrm{O}$ produced by Nitrosomonas europaea and Methylococcus capsulatus Bath. Rapid Communications in Mass Spectrometry 18, 1411-1412.

Tanimoto, T., Hatano, K., Kim, D.H., Uchiyama, H., Shoun, H., 1992. Co-Denitrification by the denitrifying system of fungus Fusarium oxysporum. FEMS Microbiology Letters 93, 177-180.

Toyoda, S., Mutobe, H., Yamagishi, H., Yoshida, N., Tanji, Y., 2005. Fractionation of $\mathrm{N}_{2} \mathrm{O}$ isotopomers during production by denitrifier. Soil Biology and Biochemistry 37, 1535-1545.

Toyoda, S., Yoshida, N., 1999. Determination of nitrogen isotopomers of nitrous oxide on a modified isotope ratio mass spectrometer. Analytical Chemistry 71, 4711-4718.

Toyoda, S., Yoshida, N., Miwa, T., Matsui, Y., Yamagishi, H., Tsunogai, U., Nojiri, Y., Tsurushima, N., 2002. Production mechanism and global budget of $\mathrm{N}_{2} \mathrm{O}$ inferred from its isotopomers in the western North Pacific. Geophysical Research Letters 29, 7-1-74.

Ussiri, D., Lal, R., 2013. Soil Emission of Nitrous Oxide and its MItigation. Springer.

van Spanning, R.J.M., Richardson, D.J., Ferguson, S.J., 2007. Chapter 1 - Introduction to the Biochemistry and Molecular Biology of Denitrification, In: Bothe, H., Ferguson, S.J., Newton, W.E. (Eds.), Biology of the Nitrogen Cycle. Elsevier, Amsterdam, pp. 3-II.

Wang, W.C., Yung, Y.L., Lacis, A.A., Mo, T., Hansen, J.E., 1976. Greenhouse effects due to man-made perturbations of trace gases. Science 194, 685-690.

Well, R., Butterbach-Bahl, K., 2010. Indirect emissions of nitrous oxide from nitrogen deposition and leaching of agricultural nitrogen, In: Smith, K. (Ed.), Nitrous Oxide and Climate Change. Earthscan, London, UK, p. 232. 
Well, R., Flessa, H., 2009. Isotopologue signatures of $\mathrm{N}_{2} \mathrm{O}$ produced by denitrification in soils. Journal of Geophysical Research: Biogeosciences 114, G02020.

Well, R., Flessa, H., Xing, L., Ju, X., Roemheld, V., 2008. Isotopologue ratios of $\mathrm{N}_{2} \mathrm{O}$ emitted from microcosms with $\mathrm{NH}_{4}{ }^{+}$fertilized arable soils under conditions favoring nitrification. Soil Biology \& Biochemistry 40, 2416-2426.

Well, R., Kurganova, I., de Gerenyu, V.L., Flessa, H., 2006. Isotopomer signatures of soilemitted $\mathrm{N}_{2} \mathrm{O}$ under different moisture conditions - A microcosm study with arable loess soil. Soil Biology \& Biochemistry 38, 2923-2933.

Wrage, N., van Groenigen, J.W., Oenema, O., Baggs, E.M., 2005. A novel dual-isotope labelling method for distinguishing between soil sources of $\mathrm{N}_{2} \mathrm{O}$. Rapid Communications in Mass Spectrometry 19, 3298-3306.

Wrage, N., Velthof, G.L., van Beusichem, M.L., Oenema, O., 2001. Role of nitrifier denitrification in the production of nitrous oxide. Soil Biology \& Biochemistry 33, 1723-1732.

Ye, R.W., Averill, B.A., Tiedje, J.M., 1994. Denitrification - Production and Consumption of Nitric oxide. Applied and Environmental Microbiology 60, 1053-1058.

Ye, R.W., Toro-Suarez, I., Tiedje, J.M., Averill, B.A., 1991. $\mathrm{H}_{2}{ }^{18} \mathrm{O}$ isotope exchange studies on the mechanism of reduction of nitric oxide and nitrite to nitrous oxide by denitrifying bacteria. Evidence for an electrophilic nitrosyl during reduction of nitric oxide. Journal of Biological Chemistry 266, 12848-12851.

Yoshida, N., Toyoda, S., 2000. Constraining the atmospheric $\mathrm{N}_{2} \mathrm{O}$ budget from intramolecular site preference in N2O isotopomers. Nature 405, 330-334.

Zhang, L., Shoun, H., 2008. Purification and functional analysis of fungal nitric oxide reductase cytochrome P450nor, In: Poole, R.K. (Ed.), Globins and Other Nitric OxideReactive Proteins, Part B, pp. 117-133.

Zumft, W.G., 1997. Cell biology and molecular basis of denitrification. Microbiology and Molecular Biology Reviews 61, 533-616.

Zumft, W.G., Körner, H., 2007. Chapter 5 - Nitrous Oxide Reductases, In: Bothe, H., Ferguson, S.J., Newton, W.E. (Eds.), Biology of the Nitrogen Cycle. Elsevier, Amsterdam, pp. 67-81. 


\section{Fungal oxygen exchange between denitrification intermediates and water}

This chapter is an article published in Rapid Communications in Mass Spectrometry, with a modified reference style:

Rohe, L., Anderson, T.-H., Braker, G., Flessa, H., Giesemann, A., Wrage-Mönnig, N. and Well, R. (2014). Fungal oxygen exchange between denitrification intermediates and water. Rapid Commun. Mass Spectrom., 28: 377-384. doi:10.1002/rcm.6790

\section{$\underline{\text { Abstract }}$}

RATIONALE: Fungi can contribute greatly to $\mathrm{N}_{2} \mathrm{O}$ production from denitrification. Therefore, it is important to quantify the isotopic signature of fungal $\mathrm{N}_{2} \mathrm{O}$. Isotopic composition of $\mathrm{N}_{2} \mathrm{O}$ can be used to identify and analyze processes of $\mathrm{N}_{2} \mathrm{O}$ production and $\mathrm{N}_{2} \mathrm{O}$ reduction. In contrast to bacteria, information about the oxygen exchange between denitrification intermediates and water during fungal denitrification is lacking, impeding the explanatory power of stable isotope methods.

METHODS: Six fungal species were anaerobically incubated with the electron acceptors nitrate or nitrite and ${ }^{18} \mathrm{O}$-labeled water to determine the oxygen exchange between denitrification intermediates and water. After seven days of incubation, gas samples were analyzed for $\mathrm{N}_{2} \mathrm{O}$ isotopologues by isotope ratio mass spectrometry.

RESULTS: All fungal species produced $\mathrm{N}_{2} \mathrm{O} . \mathrm{N}_{2} \mathrm{O}$ production was greater when nitrite was the sole electron acceptor (129 to $6558 \mathrm{nmol} \mathrm{N}_{2} \mathrm{O} \mathrm{g} \mathrm{dw}^{-1} \mathrm{~h}^{-1}$ ) than when nitrate was the electron acceptor ( 6 to $47 \mathrm{nmol} \mathrm{N}_{2} \mathrm{O} \mathrm{g} \mathrm{dw}^{-1} \mathrm{~h}^{-1}$ ). Oxygen exchange was complete with nitrate as electron acceptor in one of five fungi and with nitrite in two of six fungi. Oxygen exchange of the other fungi varied (41 to $89 \%$ with nitrite and 11 to $61 \%$ with nitrate).

CONCLUSIONS: This is the first report on oxygen exchange with water during fungal denitrification. The exchange appears to be within the range previously reported for bacterial denitrification. This adds to the difficulty of differentiating $\mathrm{N}_{2} \mathrm{O}$ producing processes based on the origin of $\mathrm{N}_{2} \mathrm{O}-\mathrm{O}$. However, the large oxygen exchange repeatedly observed for bacteria and now also fungi could lead to less variability in $\delta^{18} \mathrm{O}$ of $\mathrm{N}_{2} \mathrm{O}$ from soils, which could facilitate the assessment of the extent of $\mathrm{N}_{2} \mathrm{O}$ reduction.

KEYWORDS: nitrous oxide, nitrite reduction, fungal denitrification, ${ }^{18} \mathrm{O}$ isotope, isotope tracer 


\section{$\underline{\text { Introduction }}$}

Nitrogen $(\mathrm{N})$ fertilizer application in agriculture is the main anthropogenic source for the greenhouse gas emissions of nitrous oxide $\left(\mathrm{N}_{2} \mathrm{O}\right)$, with detrimental environmental impacts: $\mathrm{N}_{2} \mathrm{O}$ contributes to global warming and to the depletion of the stratospheric ozone layer (IPCC, 2007). $\mathrm{N}_{2} \mathrm{O}$ from soil predominantly results from microbial processes (e.g., nitrification, nitrifier denitrification and denitrification) (IPCC, 2007). During denitrification, nitrate $\left(\mathrm{NO}_{3}{ }^{-}\right)$is reduced to nitrite $\left(\mathrm{NO}_{2}{ }^{-}\right)$, gaseous nitric oxide (NO), $\mathrm{N}_{2} \mathrm{O}$ and finally dinitrogen $\left(\mathrm{N}_{2}\right)$ under anaerobic conditions (Knowles, 1982). Shoun et al. (1992) showed that under pure culture conditions fungi are capable of denitrification. Every reduction step during denitrification is characterized by a specific enzyme: dissimilatory $\mathrm{NO}_{3}{ }^{-}$reductase (dNar), dissimilatory $\mathrm{NO}_{2}{ }^{-}$reductase $(\mathrm{dNir}), \mathrm{NO}$ reductase (Nor) and $\mathrm{N}_{2} \mathrm{O}$ reductase (Nos) (Kim et al., 2009). Apart from the fungal Nor (P450nor), which differs from the bacterial enzyme, all other enzymes involved in fungal denitrification are similar to bacterial enzymes of this process (Kim et al., 2009; Shoun et al., 2012). However, most fungi lack Nos and $\mathrm{N}_{2} \mathrm{O}$ is the major end product of fungal denitrification (Shoun et al., 1992). While research activities had concentrated on bacterial denitrification processes in earlier decades, fungal denitrification received more attention lately. Recent studies indicated that in some soils, fungal $\mathrm{N}_{2} \mathrm{O}$ production from denitrification might even be greater than that of bacteria (Blagodatskaya et al., 2010; Laughlin and Stevens, 2002; Long et al., 2013; McLain and Martens, 2006). However, the fungal production pathway of $\mathrm{N}_{2} \mathrm{O}$ has not yet been sufficiently investigated and to our knowledge there is no study focusing on fungal oxygen $(\mathrm{O})$ exchange between water $\left(\mathrm{H}_{2} \mathrm{O}\right)$ and denitrification intermediates. In the following we briefly describe (I) the enzymatic steps of bacterial $\mathrm{NO}_{3}{ }^{-}$reduction to $\mathrm{N}_{2} \mathrm{O}$ and its $\mathrm{O}$ exchange, (II) existing hypotheses about the Oexchange mechanism and (III) possibilities of using ${ }^{18} \mathrm{O}$ isotopic analysis as a tool to understand production processes in order to investigate parallels to fungal denitrification and its associated $\mathrm{O}$ exchange. Bacterial denitrification and its metabolic steps including enzymes and the $\mathrm{O}$ exchange between $\mathrm{H}_{2} \mathrm{O}$ and denitrification intermediates have been investigated in several studies (Aerssens et al., 1986; Casciotti et al., 2002; Garber and Hollocher, 1982; Kool et al., 2007; Ye et al., 1991). Bacterial O exchange varies from 4 to $100 \%$ depending on species (Aerssens et al., 1986; Garber and Hollocher, 1982; Ye et al., 1991). There is no study so far that specifically targeted $\mathrm{O}$ exchange with $\mathrm{Nar}$ during $\mathrm{NO}_{3}{ }^{-}$reduction to $\mathrm{NO}_{2}{ }^{-}$. However, the active site of Nar is located in the cytoplasm, whereas the active 
site of Nir and Nor is in the periplasm (Kool et al., 2007). Kool et al. (2007) suggested that the required transport of $\mathrm{NO}_{3}{ }^{-}$as well as of $\mathrm{H}_{2} \mathrm{O}$ during $\mathrm{NO}_{3}{ }^{-}$reduction through the cytoplasmic membrane could cause smaller $\mathrm{O}$ exchange rates, which has not yet been confirmed. So far, studies have focused on bacterial $\mathrm{O}$ exchange with $\mathrm{H}_{2} \mathrm{O}$ during $\mathrm{NO}_{2}{ }^{-}$ (4 to 94\% O exchange) and NO reduction (4 to $84 \%$ O exchange) (e.g.Aerssens et al., 1986; Ye et al., 1991)). During $\mathrm{NO}_{2}{ }^{-}$reduction the Nir type did not affect the $\mathrm{O}$ exchange, whereas during NO reduction, bacteria with copper Nir type showed larger O exchange compared to bacteria with heme-cd1 Nir type (Aerssens et al., 1986). Ye et al. did not find an $\mathrm{O}$ exchange when incubating bacterial denitrifiers with $\mathrm{N}_{2} \mathrm{O}$ as sole electron acceptor, showing that $\mathrm{O}$ exchange occurs during previous reduction $\mathrm{NO}_{3}{ }^{-}$to $\mathrm{N}_{2} \mathrm{O}$ ) steps and does not result from abiotic equilibrium between $\mathrm{H}_{2} \mathrm{O}$ and $\mathrm{N}_{2} \mathrm{O}$ (Ye et al., 1991). However, Casciotti et al. (2007) examined the storage effect on O exchange between $\mathrm{NO}_{2}{ }^{-}$and $\mathrm{H}_{2} \mathrm{O}$ in autoclaved seawater and freshwater samples at $\mathrm{pH} 7.9$ during 24 days. They found remarkable $\mathrm{O}$ exchanges between 15 and $38 \%$ at $+4{ }^{\circ} \mathrm{C}$, which may indicate that a potential chemical $\mathrm{O}$ exchange in soil could exist as well, assuming that the water samples were completely free of microbial growth (Casciotti et al., 2007). During microbial reduction of $\mathrm{NO}_{3}{ }^{-}$to $\mathrm{N}_{2} \mathrm{O}$, O exchange probably occurs due to equilibration between $\mathrm{O}$ of cell-internal intermediates and the ambient water and seems to be accelerated by enzymatic activity (Brunner et al., 2005; Knöller et al., 2011). During denitrification of bacterial species with the heme-cd1 Nir type, Aerssens et al. (1986) found that $\mathrm{O}$ exchange decreased with increasing $\mathrm{NO}_{2}{ }^{-}$concentration when $\mathrm{NO}_{3}{ }^{-}$ was absent from the medium. Their explanation was that $\mathrm{NO}_{2}^{-}$was reduced by Nir to an enzyme-bound nitrosyl intermediate $\left(\mathrm{E}^{-\mathrm{NO}^{+}}\right.$or $\left.\mathrm{E}-\mathrm{NO}^{-}\right)$with a reversible dehydration (Aerssens et al., 1986). They concluded that high $\mathrm{NO}_{2}{ }^{-}$concentration enhances the $\mathrm{NO}_{2}{ }^{-}$ reduction rate to the enzyme-bound nitrosyl intermediate. In this case the reduction rate is high and limited by the reversible dehydration step (Aerssens et al., 1986) in such a way that after dehydration and the formation of the nitrosyl intermediate there is no time left for rehydration. Correspondingly, with small $\mathrm{NO}_{2}^{-}$concentrations the production rates of enzyme-bound nitrosyl intermediates decreased, resulting in sufficient time for a more reversible dehydration step and thus in greater $\mathrm{O}$ exchange between the enzyme-bound intermediates $\left(\mathrm{E}_{-} \mathrm{NO}^{+}\right.$or E-NO${ }^{-}$) and $\mathrm{H}_{2} \mathrm{O}$ (Aerssens et al., 1986). Information on the $\mathrm{O}$ exchange mechanism in the copper Nir type is lacking, but due to the different $\mathrm{O}$ exchanges observed by Ye et al., the enzymatic step of $\mathrm{NO}_{2}{ }^{-}$ reduction might differ from the heme-cd1 Nir type (Ye et al., 1991). Consequently, the 
bacterial $\mathrm{O}$ exchange seems to be dependent on reaction rates and the enzyme types involved in microbial $\mathrm{NO}_{3}{ }^{-}$reduction to $\mathrm{N}_{2} \mathrm{O}$. Based on ${ }^{18} \mathrm{O}$ tracer studies and calculated O exchange, Snider et al. suggested that $\mathrm{O}$ exchange may depend on the microbial community, but not on environmental conditions like temperature and soil moisture or $\mathrm{N}_{2} \mathrm{O}$ production (Snider et al., 2009; Snider et al., 2013).

Like the $\mathrm{N}$ isotopes, $\mathrm{O}$ isotopes of $\mathrm{N}_{2} \mathrm{O}$ can principally serve as tracers for the determination of $\mathrm{N}_{2} \mathrm{O}$ production pathways. Natural $\mathrm{O}$ sources of $\mathrm{N}_{2} \mathrm{O}$ from the different production pathways are (I) air oxygen $\left(\mathrm{O}_{2}\right)$ during ammonia oxidation of nitrification with $\mathrm{N}_{2} \mathrm{O}$ formation from the hydroxylamine intermediate; (II) $\mathrm{H}_{2} \mathrm{O}-\mathrm{O}$ and $\mathrm{O}_{2}$ during nitrifier denitrification, and (III) $\mathrm{NO}_{3}{ }^{-} \mathrm{O}$ and $\mathrm{H}_{2} \mathrm{O}-\mathrm{O}$ (due to $\mathrm{O}$ exchange) during denitrification (Kool et al., 2007; Ostrom and Ostrom, 2011; Wrage et al., 2005). The $\mathrm{O}$ of $\mathrm{NO}_{3}{ }^{-}$can be affected by $\mathrm{H}_{2} \mathrm{O}-\mathrm{O}$ and $\mathrm{O}_{2}$ as well, if the $\mathrm{NO}_{3}{ }^{-}$comes from nitrification (Kool et al., 2007). Hence, differences in isotopic compositions of all $\mathrm{O}$ precursors, $\mathrm{O}$ exchange with $\mathrm{H}_{2} \mathrm{O}$, and isotope effects of enzymatic reaction and of $\mathrm{O}$ exchange affect $\delta^{18} \mathrm{O}$-values of produced $\mathrm{N}_{2} \mathrm{O}\left(\delta^{18} \mathrm{O}-\mathrm{N}_{2} \mathrm{O}\right)$. Snider et al. summarized studies focusing on $\delta^{18} \mathrm{O}-\mathrm{N}_{2} \mathrm{O}$ from nitrification and they specified a $\delta^{18} \mathrm{O}-\mathrm{N}_{2} \mathrm{O}$ range from +13 to $+35 \%$, whereas $\delta^{18} \mathrm{O}-\mathrm{N}_{2} \mathrm{O}$ from denitrification might reach larger $\delta^{18} \mathrm{O}$ $\mathrm{N}_{2} \mathrm{O}\left(>35 \%\right.$ ) due to isotopic fractionation during $\mathrm{NO}_{3}{ }^{-}$reduction (Snider et al., 2012, 2013). However, in cases of larger $\mathrm{O}$ exchanges with $\mathrm{H}_{2} \mathrm{O}$ during denitrification, indistinguishable $\delta^{18} \mathrm{O}-\mathrm{N}_{2} \mathrm{O}$ could occur from different $\mathrm{N}_{2} \mathrm{O}$ sources. Moreover, $\mathrm{N}_{2} \mathrm{O}$ reduction to $\mathrm{N}_{2}$ leads to an increase in $\delta^{18} \mathrm{O}$-values of residual $\mathrm{N}_{2} \mathrm{O}$ (Ostrom and Ostrom, 2011). Estimation of $\mathrm{N}_{2} \mathrm{O}$ reduction might be possible by analyzing $\delta^{18} \mathrm{O}-\mathrm{N}_{2} \mathrm{O}$. To this end, effects on $\delta^{18} \mathrm{O}-\mathrm{N}_{2} \mathrm{O}$ during $\mathrm{N}_{2} \mathrm{O}$ production by nitrification and bacterial/fungal denitrification must be known. However, the interpretation of $\delta^{18} \mathrm{O}-\mathrm{N}_{2} \mathrm{O}$ is difficult due to the mentioned possible Oexchange that could occur between denitrification intermediates and $\mathrm{H}_{2} \mathrm{O}$ (Kool et al., 2007). These factors complicate the use of $\delta^{18} \mathrm{O}-\mathrm{N}_{2} \mathrm{O}$ for differentiation between nitrification and denitrification processes. So far, information on $\mathrm{O}$ exchange between $\mathrm{H}_{2} \mathrm{O}$ and intermediates during fungal denitrification is lacking. Particularly the fungal P450nor, which is different from bacterial Nors, could cause differences between fungal and bacterial $\mathrm{O}$ exchange. Information about the factors controlling $\delta^{18} \mathrm{O}-\mathrm{N}_{2} \mathrm{O}$ produced by fungal denitrification is necessary to differentiate between the $\mathrm{N}_{2} \mathrm{O}$ production pathways and to elucidate $\mathrm{N}_{2} \mathrm{O}$ reduction to $\mathrm{N}_{2}$ (Well et al., 2012). 
The aim of this study was to quantify $\mathrm{O}$ exchange with $\mathrm{H}_{2} \mathrm{O}$ during fungal denitrification and to determine the influence of the two electron acceptors $\mathrm{NO}_{3}{ }^{-}$and $\mathrm{NO}_{2}^{-}$on $\mathrm{N}_{2} \mathrm{O}$ production and $\mathrm{O}$ exchange. The mode of fungal $\mathrm{O}$ exchange was compared with bacterial $\mathrm{O}$ exchange known from literature to see if differences exist (Aerssens et al., 1986; Garber and Hollocher, 1982; Ye et al., 1991). To this end, we incubated six different fungal species under denitrifying conditions with ${ }^{18} \mathrm{O}$-labeled $\mathrm{H}_{2} \mathrm{O}$ and analyzed $\delta^{18} \mathrm{O}-\mathrm{N}_{2} \mathrm{O}$.

\section{Experimental}

\section{Microorganisms}

Six ubiquitous soil fungi (Domsch et al., 1980) known to be capable of denitrification (Shoun et al., 1992) were used to investigate the $\mathrm{O}$ exchange between ${ }^{18} \mathrm{O}$-labeled $\mathrm{H}_{2} \mathrm{O}$ and denitrification intermediates. Chaetomium funicola JCM 22733, Fusarium oxysporum JCM 11502 and Trichoderma hamatum JCM 187 were obtained from the Japan Collection of Microorganisms (Saitama, Japan), while Cylindrocarpon lichenicola NBRC 30561, Fusarium solani fsp. pisi NBRC 9425 and Fusarium decemcellulare NBRC 31657 were received from the NITE Biological Research Center (Chiba, Japan). Except for C. funicola, which belongs to the order Sordariales, all other species belong to the order Hypocreales. Shoun et al. did not find $\mathrm{N}_{2}$ production by $F$. oxysporum and $F$. decemcellulare and only a small $\mathrm{N}_{2}$ production by the other fungi compared to bacteria capable of $\mathrm{N}_{2} \mathrm{O}$ reduction (Shoun et al., 1992).

\section{Experimental procedure}

According to the protocol of Shoun et al. (1992) the supplied stem cultures were transferred to $100 \mathrm{~mL}$ sterile fungal medium in an Erlenmeyer flask with cotton wool plugs. The culture medium contained $1 \%$ glucose, $0.2 \%$ peptone, $0.02 \% \mathrm{MgSO}_{4} \cdot 7$ $\mathrm{H}_{2} \mathrm{O}, 2 \mathrm{ppm} \mathrm{CoCl}_{2} \cdot 6 \mathrm{H}_{2} \mathrm{O}, 2 \mathrm{ppm} \mathrm{FeSO}_{4} \cdot 7 \mathrm{H}_{2} \mathrm{O}$ and 0.01 mol potassium phosphate (pH 7.4) (Shoun et al., 1992). The inoculated medium was incubated aerobically at $22{ }^{\circ} \mathrm{C}$ in the dark in a rotary shaker for three to seven days (100 rpm) as a preparatory culture (Shoun et al., 1992). Incubation time depended on the growth increase. When the fungal mycelium had grown well (mycelium was visible in the medium), triplicates 
of $10 \mathrm{~mL}$ pre-culture were transferred to fresh medium $(38.47 \mathrm{~mL})$ each in a $120 \mathrm{~mL}$ crimp neck vial (La-Pha-Pack GmbH, Langerwehe, Germany) with a butyl stopper; adopting the protocol of Shoun et al., either $10 \mathrm{mmol}$ potassium nitrate $\left(\mathrm{KNO}_{3}\right)$ or 5 mmol sodium nitrite $\left(\mathrm{NaNO}_{2}\right)$ were added as electron acceptor for denitrification (Shoun et al., 1992). This medium was supplemented with $1.53 \mathrm{~mL}$ filter-sterilized $(0.2 \mu \mathrm{m}){ }^{18} \mathrm{O}-$-labeled $\mathrm{H}_{2} \mathrm{O}$ (10 atom\% (at\%), Sigma-Aldrich, Taufenstein, Germany) to reach a 0.5 at $\%{ }^{18} \mathrm{O}$-labeling of $\mathrm{H}_{2} \mathrm{O}$ in the medium, giving a total volume of $50 \mathrm{~mL}$ in every vial. To obtain anaerobic conditions, the headspace of the vials was purged for 10 min with filter-sterilized $\mathrm{N}_{2}$. During the purging, the vials were stirred manually to expulse the dissolved oxygen. Following Shoun et al. after seven days of incubation in the dark $\left(22{ }^{\circ} \mathrm{C}\right)$ in a rotary shaker $(120 \mathrm{rpm})$, duplicates of gas samples $(14 \mathrm{~mL})$ were collected and transferred to evacuated sampling vials (12 mL Exetainer ${ }^{\circledR}$, Labco Ltd., Lampeter, UK) with a syringe (Shoun et al., 1992).

To determine the $\mathrm{N}_{2} \mathrm{O}$ production per fungal biomass the complete medium of each vial at the end of the 7-day incubation was centrifuged (5236 $\mathrm{xg}$ for $30 \mathrm{~min}$ ) and washed twice with distilled $\mathrm{H}_{2} \mathrm{O}$. Subsequently, the supernatant was decanted and the cells oven dried at $105^{\circ} \mathrm{C}$ for 48 hours to determine the dry weight (dw) of the fungi.

In parallel, triplicates of $50 \mathrm{~mL}$ fresh medium containing $5 \mathrm{mmol} \mathrm{NaNO}_{2}{ }^{-}$or $10 \mathrm{mmol}$ $\mathrm{KNO}_{3}{ }^{-}$without fungi were incubated according to the same protocol as above to analyze the chemical production of $\mathrm{N}_{2} \mathrm{O}$. After seven days of incubation, the controls without fungal species did not show any $\mathrm{N}_{2} \mathrm{O}$ production with $\mathrm{NO}_{3}{ }^{-}$as electron acceptor. However, in the presence of $\mathrm{NO}_{2}^{-}$as electron acceptor there was minute $\mathrm{N}_{2} \mathrm{O}$ production, $<0.01 \mathrm{nmol} \mathrm{h}^{-1}$. This small chemical production was not enough $\mathrm{N}_{2} \mathrm{O}$ for isotopic analysis and negligible compared to the observed fungal production of $\mathrm{N}_{2} \mathrm{O}$. The medium was clear and did not show bacterial or fungal growth after seven days of incubation.

\section{Analysis of gas samples}

Headspace samples were analyzed by gas chromatography (GC, Agilent 7890A, Agilent, Böblingen, Germany) for $\mathrm{N}_{2} \mathrm{O}$ concentration. The detection limit of GC analysis of our incubation was $0.01 \mathrm{nmol} \mathrm{h}^{-1}$ with a measurement precision of $1 \%$. Dissolved $\mathrm{N}_{2} \mathrm{O}$ in the medium was calculated by Henry's law (Davidson and Firestone, 1988). In the following, the $\mathrm{N}_{2} \mathrm{O}$ production implies gas produced in the headspace as 
well as the calculated dissolved $\mathrm{N}_{2} \mathrm{O}$. Afterwards, samples were analyzed for $\mathrm{N}_{2} \mathrm{O}$ isotopologues by isotope ratio mass spectrometry (IRMS, Thermo Fisher Scientific, Bremen, Germany) using a pre-concentrator (PreCon, Thermo-Finnigan, Bremen, Germany) interfaced to a Delta V isotope ratio mass spectrometer (Brand, 1995; Köster et al., 2013; Toyoda and Yoshida, 1999). The typical analytical precision for natural abundance samples of IRMS analysis was $0.1 \%$ and $0.2 \%$ for $\delta^{15} \mathrm{~N}_{\text {bulk }}$ and $\delta^{18} \mathrm{O}$ values, respectively. There are no commercially available $\mathrm{N}_{2} \mathrm{O}$ standards enriched with ${ }^{18} \mathrm{O}$. To check the accuracy of ${ }^{18} \mathrm{O}$-analysis of enriched $\mathrm{N}_{2} \mathrm{O}$ using non-enriched standards, we evaluated linearity by diluting the $\mathrm{N}_{2} \mathrm{O}$ sample with the largest ${ }^{18} \mathrm{O}$ enrichment of a pre-experiment (measured value of 0.552 at\%) with non-labeled $\mathrm{N}_{2} \mathrm{O}$. A dilution series of eight dilution levels was prepared with ${ }^{18} \mathrm{O}$ enrichments between 0.208 and 0.552 at $\%$ and analyzed in triplicates. The non-labeled $\mathrm{N}_{2} \mathrm{O}$ was our laboratory working standard with 0.208 at $\%{ }^{18} \mathrm{O}$. A close correlation between measured and expected ${ }^{18} \mathrm{O}$-values $\left(\mathrm{R}^{2}=0.992\right)$ showed that the response was linear and the calibration with our non-labeled working standard was thus valid. The standard deviation within triplicate measurements of ${ }^{18} \mathrm{O}$ enriched samples varied between 0.001 and 0.004 at\%, which can be attributed to influences of dilution and to analytical errors.

\section{${ }^{18} \mathrm{O}$ analysis of $\mathrm{H}_{2} \mathrm{O}$}

We made a plausibility check of the ${ }^{18} \mathrm{O}$ enrichment of $\mathrm{H}_{2} \mathrm{O}$ in the medium to verify our labeling target of 0.5 at $\%{ }^{18} \mathrm{O}$. We used a cavity ring-down laser spectrometer (model $\mathrm{L}$ 1115-I, Picarro, Santa Clara, USA) suitable for analyzing $\mathrm{H}_{2} \mathrm{O}$ as liquid or vapor. For calibration, we used three working standards between 0.201 and 0.198 at $\%{ }^{18} \mathrm{O}$ (standard deviation $<1.4 \times 10^{-5}$ at\%) measured against Vienna Standard Mean Ocean Water (VSMOW). The ${ }^{18} \mathrm{O}$ enriched medium was distilled to obtain pure $\mathrm{H}_{2} \mathrm{O}$ for liquid analysis. Due to the high ${ }^{18} \mathrm{O}$ enrichment, isotopic fractionation during distillation was assumed to be negligible. Samples were analyzed in triplicates in a dilution series with three dilution levels produced with distilled $\mathrm{H}_{2} \mathrm{O}$ with known ${ }^{18} \mathrm{O}$-value from the laboratory (0.198 $\pm 2 \times 10^{-5}$ at $\left.\left.\%\right): 1\right)$ pure distilled water and dilutions of 2) 1:100 and 3) 1:10 (medium: distilled water). We found a linear response between analyzed ${ }^{18} \mathrm{O}-$ values and the dilution levels $(0,0.01$ and 0.1$)\left(\mathrm{R}^{2}=0.999\right)$. The ${ }^{18} \mathrm{O}$ analysis of the

${ }^{18} \mathrm{O}$-labeled medium showed the expected value of $0.49 \pm 0.01$ at $\%{ }^{18} \mathrm{O}$. 


\section{Calculations}

Assuming there is no $\mathrm{N}_{2} \mathrm{O}$ reduction (Shoun et al., 1992) and no loss of gas (e.g., loss of $\mathrm{NO}$ ), the reaction progress of denitrification can be calculated as follows:

Reaction progress $(\%)=\frac{\text { final } N_{2} O-N}{\text { initial } N O x-N} * 100$

where final $\mathrm{N}_{2} \mathrm{O}-\mathrm{N}$ is the amount of $\mathrm{N}_{2} \mathrm{O}-\mathrm{N}$ and the initial $N O_{x}-\mathrm{N}$ is the offered precursor amount $\left(5 \mathrm{mmol} \mathrm{NaNO}_{2}\right.$ or $10 \mathrm{mmol} \mathrm{KNO}_{3}$ ).

The ${ }^{18} \mathrm{O}$ enrichment of $\mathrm{N}_{2} \mathrm{O}$ was used to determine the incorporation of $\mathrm{O}$ from ${ }^{18} \mathrm{O}$ enriched $\mathrm{H}_{2} \mathrm{O}$ into $\mathrm{N}_{2} \mathrm{O}$ produced during denitrification. Isotope fractionation during $\mathrm{O}$ exchange and reduction of $\mathrm{N}$-oxides can be assumed to be negligible because of the high ${ }^{18} \mathrm{O}$ enrichment in $\mathrm{H}_{2} \mathrm{O}$. The extent of $\mathrm{O}$ incorporation from $\mathrm{H}_{2} \mathrm{O}$ into $\mathrm{N}_{2} \mathrm{O}$ can thus be calculated as (Kool et al., 2009a):

${ }^{18} \mathrm{O}$ exchange $(\%)=100 * \frac{{ }^{18} \mathrm{O}_{\left(\mathrm{N}_{2} \mathrm{O}\right)}}{\left.{ }^{18} \mathrm{O}_{(\mathrm{O}} \mathrm{O}\right)}$

where ${ }^{18} \mathrm{O}_{(\mathrm{N} 2 \mathrm{O})}$ and ${ }^{18} \mathrm{O}_{(\mathrm{H} 2 \mathrm{O})}$ denote $\mathrm{O}$ enrichments of $\mathrm{H}_{2} \mathrm{O}$ and $\mathrm{N}_{2} \mathrm{O}$, respectively in terms of atom\% excess (at\%exc). The latter is given as

$a t \%_{\text {exc }}=a t \%_{\text {sample }}-a t \%_{\text {background }}$

where at $\%_{\text {sample }}$ denotes the ${ }^{18} \mathrm{O}$ abundance of the $\mathrm{N}_{2} \mathrm{O}$ sample and at $\%_{\text {background }}$ denotes the ${ }^{18} \mathrm{O}$ abundance of the $\mathrm{N}_{2} \mathrm{O}$ precursors $\mathrm{NO}_{3}{ }^{-}$and $\mathrm{NO}_{2}{ }^{-}$, which were analyzed with the denitrifier method according to Casciotti $e$ t al. using three working standards (USGS34, USGS35 and IAEA-NO-3), with a precision of $\leq 1.3 \times 10^{-4}$ at\% (Casciotti et al., 2002). All three working standards are $\mathrm{NO}_{3}{ }^{-}$salts, but Casciotti et al. found that the $\mathrm{O}$ exchange between $\mathrm{H}_{2} \mathrm{O}$ and $\mathrm{NO}_{3}{ }^{-}$or $\mathrm{NO}_{2}{ }^{-}$was indistinguishable during denitrification by $P$. aureofaciens, while the $\mathrm{O}$ fractionation from $\mathrm{NO}_{2}^{-}$was less than that from $\mathrm{NO}_{3}{ }^{-}$ (Casciotti et al., 2007). Consequently, in the absence of $\mathrm{NO}_{3}{ }^{-}$, the denitrifier method can be used for $\mathrm{NO}_{2}^{-}$if complete conversion of the substrate is given.(Casciotti et al., 2007) With $\mathrm{N}$ isotopes, we ensured the complete conversion of the $\mathrm{NO}_{3}{ }^{-}$standards to $\mathrm{N}_{2} \mathrm{O}$ by P. aureofaciens. The resulting ${ }^{18} \mathrm{O}$-values for $\mathrm{NO}_{3}{ }^{-}$and $\mathrm{NO}_{2}{ }^{-}$were 0.206 and 0.196 at\%, respectively. Some fungi yielded an $\mathrm{O}$ exchange slightly above $100 \%$. This could be caused by cumulative errors, i.e. derived from precision of dilution of ${ }^{18} \mathrm{O}$-labeled and non-labeled $\mathrm{H}_{2} \mathrm{O}$ (about 4\%), analytical precision (about $1 \%$ of IRMS measurement), 
inaccuracy in transferring the viscous medium to the fresh autoclaved medium after fungal growth and ${ }^{18} \mathrm{O}$-labeled $\mathrm{H}_{2} \mathrm{O}$ in the vial (about $2 \%$ ).

\section{Statistical analysis}

For statistical analysis, the $\mathrm{N}_{2} \mathrm{O}$ production was based on fungal dry weight (dw). $\mathrm{N}_{2} \mathrm{O}$ production was $\log ^{10}$-transformed to achieve normality and homogeneity of variance of the residuals. Significant effects of fungal species and electron acceptors on fungal biomass $(\mathrm{dw}), \mathrm{N}_{2} \mathrm{O}$ production and oxygen exchange were tested using two-factorial ANOVAs. We made a pairwise comparison with Tukey's HSD test for interactions between species and electron acceptors influencing the $\mathrm{N}_{2} \mathrm{O}$ production. For all ANOVAs, T. hamatum and C. funicola were excluded because electron acceptor effects could only be analyzed for species producing $\mathrm{N}_{2} \mathrm{O}$ from $\mathrm{NO}_{2}^{-}$as well as from $\mathrm{NO}_{3}^{-}$ treatments with triplicates. The significance of electron acceptor on $\mathrm{N}_{2} \mathrm{O}$ production of all fungal species was tested with a t-test. The significance level $(\alpha)$ for ANOVAs was 0.05 . We used linear regression to estimate the relationship between oxygen exchange and $\mathrm{N}_{2} \mathrm{O}$ production. Statistical analysis was performed using $\mathrm{R}$ (R Core Team 2013. R: A language and environment for statistical computing. R Foundation for Statistical Computing, Vienna, Austria).

\section{$\underline{\text { Results }}$}

\section{Evidence of fungal growth}

Fungal growth in the medium (turbid, globose or mixture of both) differed among species (Table 1). Cy. lichenicola grew unstructured and caused a turbidity in the medium. The culture was examined under a microscope to check for bacterial contamination. No bacterial contamination was visible. After seven days of anaerobic growth, the biomass of fungi with $\mathrm{NO}_{3}{ }^{-}$was much higher for $F$. oxysporum and $F$. 
solani fsp. pisi than with $\mathrm{NO}_{2}^{-}$, and thus differed significantly between electron acceptors $(P<0.001)$ and among species $(P<0.001)$.

\section{$\mathrm{N}_{2} \mathrm{O}$ production}

All fungal species produced $\mathrm{N}_{2} \mathrm{O}$ (Table 1), either solely with $\mathrm{NO}_{2}{ }^{-}($C. funicola) or with both electron acceptors $\mathrm{NO}_{2}^{-}$and $\mathrm{NO}_{3}^{-}$. Compared to $\mathrm{NO}_{3}^{-}$with an $\mathrm{N}_{2} \mathrm{O}$ production between 6 and $47 \mathrm{nmol} \mathrm{N} \mathrm{N}_{2} \mathrm{O} \mathrm{dw}{ }^{-1} \mathrm{~h}^{-1}, \mathrm{NO}_{2}^{-}$as electron acceptor led to significantly greater $\mathrm{N}_{2} \mathrm{O}$ production $(\mathrm{P}<0.001)$ : between 129 and $6558 \mathrm{nmol} \mathrm{N}_{2} \mathrm{O} \mathrm{g} \mathrm{dw}{ }^{-1} \mathrm{~h}^{-1}$ (Table 1). The $\mathrm{N}_{2} \mathrm{O}$ production differed significantly among species $(P=0.003)$. The paired comparison of $\mathrm{N}_{2} \mathrm{O}$ production in dependence of fungal species with the different electron acceptors showed that the large $\mathrm{N}_{2} \mathrm{O}$ production by $F$. oxsporum with $\mathrm{NO}_{2}{ }^{-}$was predominantly responsible for the significant species effect. However, excluding $F$. oxysporum because of its remarkably great $\mathrm{N}_{2} \mathrm{O}$ production from the ANOVA showed that there was still an electron acceptor effect $(P<0.001)$ on $\mathrm{N}_{2} \mathrm{O}$ production, but there was also a species effect $(P=0.001)$ and an influence of the electron acceptors on species in producing $\mathrm{N}_{2} \mathrm{O}(P=0.002)$. The t-test with all fungal species showed an electron acceptor effect on $\mathrm{N}_{2} \mathrm{O}$ production as well $(P<0.001)$. C. funicola, the only fungus belonging to the order of Sordariales, showed the least $\mathrm{N}_{2} \mathrm{O}$ production with $\mathrm{NO}_{2}^{-}\left(129 \mathrm{nmol} \mathrm{N} 2 \mathrm{O} \mathrm{g} \mathrm{dw}{ }^{-1} \mathrm{~h}^{-1}\right)$ among all species (other species between 811 and 6558

nmol $\mathrm{N}_{2} \mathrm{O} \mathrm{g} \mathrm{dw}{ }^{-1} \mathrm{~h}^{-1}$ ) and did not produce detectable amounts of $\mathrm{N}_{2} \mathrm{O}$ with $\mathrm{NO}_{3}{ }^{-}$as electron acceptor. The calculated reaction progress based on produced $\mathrm{N}_{2} \mathrm{O}$ (Eq. 1) of F. oxysporum with $\mathrm{NO}_{2}^{-}$was $11 \%$ and for all other species it was $<2.3 \%$ (Table 1), showing that only a small fraction of the added electron acceptors was used for denitrification during the incubation period.

\section{Oxygen exchange between water and intermediates}

The $\mathrm{N}_{2} \mathrm{O}$ produced by the fungal species after seven days was enriched in ${ }^{18} \mathrm{O}$ (Table 1 ) due to $\mathrm{O}$ exchange between ${ }^{18} \mathrm{O}$-labeled $\mathrm{H}_{2} \mathrm{O}$ and denitrification intermediates. The $\mathrm{O}$ exchange was significantly dependent on electron acceptors $(P<0.001)$ and fungal species $(P<0.001)$ and the electron acceptors influenced the species in their $\mathrm{O}$ exchange $(P<0.001)$. With $\mathrm{NO}_{2}{ }^{-}, \mathrm{O}$ exchange was higher than with $\mathrm{NO}_{3}{ }^{-}$as electron acceptor, with the exception of $F$. solani fsp. pisi, which had higher $\mathrm{O}$ exchange with 
$\mathrm{NO}_{3}{ }^{-}$compared to the treatment with $\mathrm{NO}_{2}{ }^{-}$. In the presence of $\mathrm{NO}_{2}{ }^{-}, F$. oxysporum and T. hamatum had a calculated $\mathrm{O}$ incorporation of $>100 \%$, suggesting complete $\mathrm{O}$ exchange. The same result was obtained for $F$. solani fsp. pisi with $\mathrm{NO}_{3}{ }^{-}$.

The $\mathrm{O}$ exchange from labeled $\mathrm{H}_{2} \mathrm{O}$ in $\mathrm{N}_{2} \mathrm{O}$ varied between 74 and $106 \%$ in the $\mathrm{NO}_{2}{ }^{-}$ treatments of the five species belonging to the order Hypocreales (Table 1). The only Sordariales species had a lower $\mathrm{O}$ exchange of $41 \%$ in the $\mathrm{NO}_{2}{ }^{-}$treatment. In the $\mathrm{NO}_{3}{ }^{-}$ treatment, the $\mathrm{O}$ exchange varied between 11 and $109 \%$ for the fungal species of Hypocreales. With both electron acceptors, $\mathrm{O}$ exchange correlated positively with $\mathrm{N}_{2} \mathrm{O}$ production (Figure 1). The correlation was significant for both electron acceptors $\left(P<0.001\right.$ for $\mathrm{NO}_{2}{ }^{-}$and $P=0.007$ for $\left.\mathrm{NO}_{3}{ }^{-}\right)$.

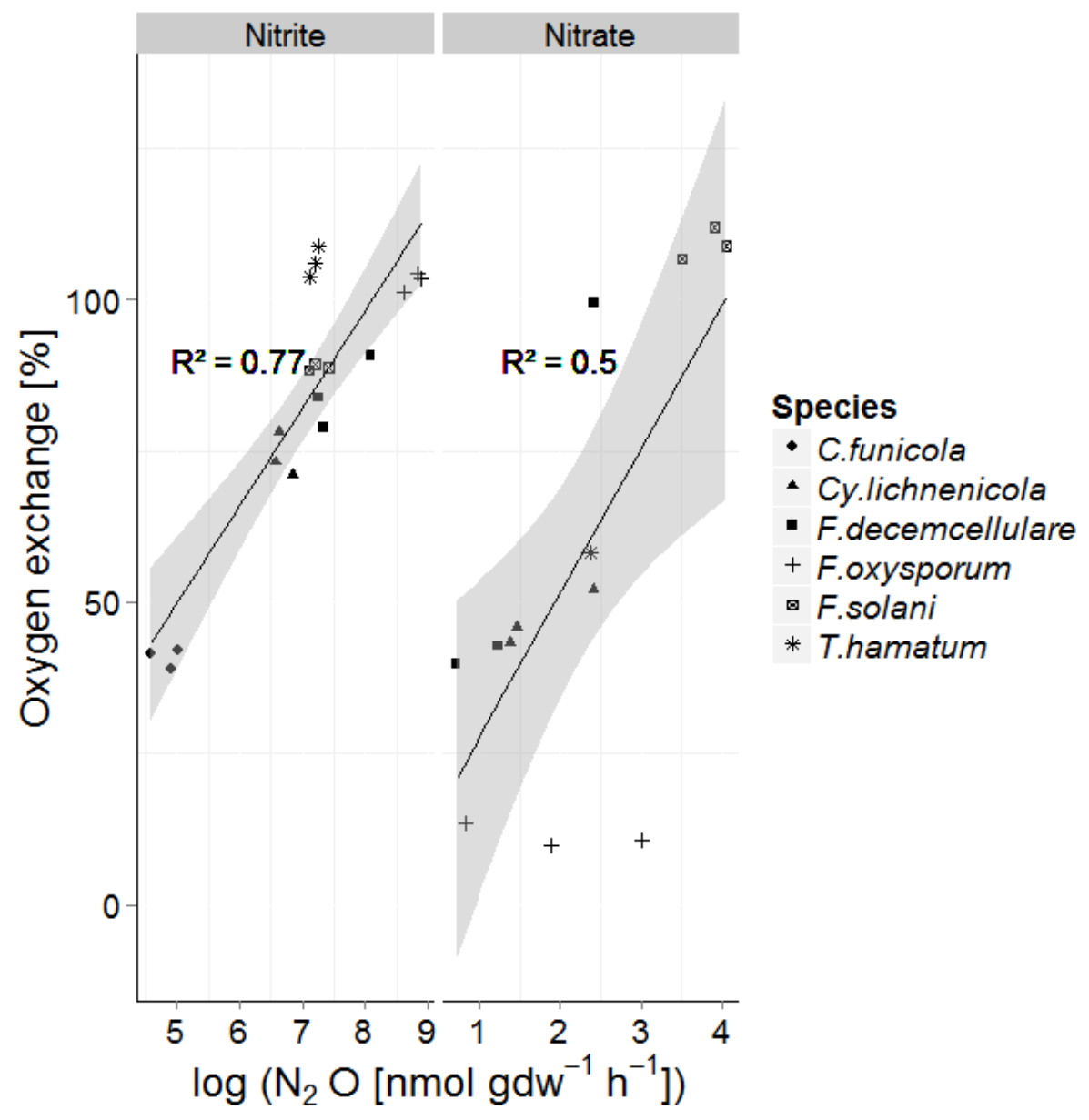

Figure 1: $\mathrm{O}$ exchange (\%) between $\mathrm{H}_{2} \mathrm{O}$ and intermediates during denitrification with $\mathrm{NO}_{2}{ }^{-}$and $\mathrm{NO}_{3}{ }^{-}$depending on the log-transformed $\mathrm{N}_{2} \mathrm{O}$ production after seven days of incubation by six different fungal species with linear regression and 95\% confidence interval (Regression for $\left.\mathrm{NO}_{2}{ }^{-} \mathrm{y}=-30.828+15.559 x ; \mathrm{NO}_{3}{ }^{-} \mathrm{y}=3.998+17.783 \mathrm{x}\right)$. 
Chapter 2

Table 1: Results from incubations of six different fungal species (standard deviation in brackets, $\mathrm{n}=3$ )

\begin{tabular}{|c|c|c|c|c|c|c|c|}
\hline Species & $\begin{array}{l}\text { Electron } \\
\text { acceptor }\end{array}$ & $\begin{array}{c}\text { Appearance } \\
\text { of fungal } \\
\text { culture }^{1}\end{array}$ & Biomass $^{2}[\mathrm{~g}]$ & $\begin{array}{l}\mathrm{N}_{2} \mathrm{O} \text { production } \\
{\left[\mathrm{nmol} \mathrm{g}^{-1} \mathrm{~h}^{-1}\right]}\end{array}$ & $\begin{array}{c}{ }^{18} \mathrm{O} \\
\text { atom\% excess } \\
{[\%]}\end{array}$ & $\begin{array}{c}\mathrm{O} \\
\text { exchange } \\
{[\%]}\end{array}$ & $\begin{array}{c}\text { Reaction } \\
\text { progress } \\
{[\%]}\end{array}$ \\
\hline Cy. lichnenicola & $\mathrm{NO}_{2}^{-}$ & $\mathrm{t}$ & $0.023(0.002)$ & $811.28(122.06)$ & $0.22(0.01)$ & $74.1(3.7)$ & $1.06(0.16)$ \\
\hline F. decemcellulare & $\mathrm{N}$ & $\mathrm{g}$ & $0.015(0.002)$ & $1425.60(1038.89)$ & $0.25(0.02)$ & $84.2(6.4)$ & $1.27(0.86)$ \\
\hline F. oxysporum & $\mathrm{N}$ & $\mathrm{gt}$ & $0.029(0.002)$ & 6557.67 (891.06) & $0.30(0.005)$ & $103.0(1.6)$ & $10.53(1.43)$ \\
\hline F. solani fsp. pisi & $\mathrm{N}$ & gt & $0.029(0.003)$ & $1224.24(241.77)$ & $0.26(0.001)$ & $88.8(0.5)$ & $2.31(0.39)$ \\
\hline T. hamatum & $\mathrm{N}$ & $\mathrm{g}$ & $0.006(0.001)$ & $1339.06(86.48)$ & $0.31(0.01)$ & $106.2(2.5)$ & $0.41(0.03)$ \\
\hline C. funicola & $\mathrm{N}$ & $\mathrm{g}$ & $0.035(0.004)$ & $128.98(27.79)$ & $0.12(0.005)$ & $40.9(1.6)$ & $0.26(0.05)$ \\
\hline Cy. lichnenicola & $\mathrm{N}$ & $\mathrm{t}$ & $0.020(0.004)$ & $6.44(4.03)$ & $0.21(0.11)$ & $47.1(4.5)$ & $0.01(0.003)$ \\
\hline F. decemcellulare & $\mathrm{N}$ & $\mathrm{g}$ & $0.048(0.009)$ & $6.24(5.57)$ & $0.19(0.10)$ & $60.7(33.6)$ & $0.01(0.01)$ \\
\hline F. oxysporum & $\mathrm{N}$ & gt & $0.048(0.009)$ & $16.56(15.88)$ & $0.04(0.01)$ & $11.3(1.9)$ & $0.01(0.01)$ \\
\hline F. solani fsp. pisi & $\mathrm{N}$ & gt & $0.018(0.004)$ & $46.90(12.43)$ & $0.27(0.09)$ & $109.2(2.7)$ & $0.03(0.01)$ \\
\hline T. hamatum* & $\mathrm{N}$ & $\mathrm{g}$ & $0.009(0.001)$ & $10.7^{*}$ & $0.18^{*}$ & $58 *$ & $0.003^{*}$ \\
\hline C.funicola & $\mathrm{N}$ & $\mathrm{g}$ & $0.014(0.006)$ & n.d. & n.d. & n.d. & n.d. \\
\hline
\end{tabular}

n.d. = not detectable; $C$. funicola did not produce $\mathrm{N}_{2} \mathrm{O}$ with $\mathrm{NO}_{3}{ }^{-}$as electron acceptor.

${ }^{1}$ The appearance of fungal cultures in the medium was turbid $(\mathrm{t})$, globose $(\mathrm{g})$ or a mixture of globose and turbid $(\mathrm{gt})$.

${ }^{2}$ The average biomass ( $g$ dw) of each fungal species after the experiment was used to base the $\mathrm{N}_{2} \mathrm{O}$ production on fungal biomass.

* Only one sample of $T$. hamatum with $\mathrm{NO}_{3}{ }^{-}$produced sufficient $\mathrm{N}_{2} \mathrm{O}$ for isotopic analysis. 


\section{$\underline{\text { Discussion }}$}

\section{$\mathrm{N}_{2} \mathrm{O}$ production}

Our studies with six pure fungal cultures showed that $\mathrm{N}_{2} \mathrm{O}$ production varied among species. Further, $\mathrm{N}_{2} \mathrm{O}$ production was larger with $\mathrm{NO}_{2}{ }^{-}$as electron acceptor than with $\mathrm{NO}_{3}{ }^{-}$. Comparable results were reported by Shoun et al. (1992). A higher rate of $\mathrm{NO}_{2}{ }^{-}$reduction compared to $\mathrm{NO}_{3}{ }^{-}$reduction could result from the attempt to reduce the toxicity of $\mathrm{NO}_{2}^{-}$in the medium and could lead to the observed higher $\mathrm{N}_{2} \mathrm{O}$ production rates with $\mathrm{NO}_{2}{ }^{-}$as electron acceptor. Cleemput and Samater (1995) conducted soil experiments with $\mathrm{NO}_{2}{ }^{-}$and found a high abundance of bacteria capable of $\mathrm{NO}_{2}^{-}$reduction in areas of high $\mathrm{NO}_{2}{ }^{-}$concentrations, supporting the previously described toxicity avoidance. Previous studies by Shoun et al. (1992) with $\mathrm{NO}_{3}{ }^{-}$as electron acceptor detected $\mathrm{N}_{2} \mathrm{O}$ production from $T$. hamatum, but not from the other fungal species we examined. In addition to Shoun et al. other studies also revealed that not all fungal species are capable of $\mathrm{NO}_{3}{ }^{-}$reduction, similar to our results for $C$. funicola (Bollag and Tung, 1972; Morozkina and Kurakov, 2007; Shoun et al., 1992; Takaya et al., 2003). Our results confirm that the fungal reduction of $\mathrm{NO}_{3}{ }^{-}$to $\mathrm{NO}_{2}{ }^{-}$proceeded at a low rate, whereas $\mathrm{NO}_{2}^{-}$reduction to $\mathrm{N}_{2} \mathrm{O}$ is much faster.

\section{O exchange}

The observed range of fungal $\mathrm{O}$ exchange (between $11 \%$ and full exchange) is consistent with results for several pure bacterial cultures (between 4 and 100\%) (Aerssens et al., 1986; Casciotti et al., 2002; Garber and Hollocher, 1982; Knöller et al., 2011; Shearer and Kohl, 1988; Ye et al., 1991). In soil experiments conducted by Snider et al. (2013), Well and Flessa (2009) and Kool et al. (2009b) O exchange was always relatively large (> 65\%). Snider et al. found $\mathrm{O}$ exchanges of 40 to $50 \%$ in stream sediments (Snider et al., 2013). Kool et al. (2009b) found almost complete $\mathrm{O}$ exchange with ${ }^{18} \mathrm{O}$-labeled $\mathrm{H}_{2} \mathrm{O}$ in several soils and concluded that the ${ }^{18} \mathrm{O}$ signature of $\mathrm{N}_{2} \mathrm{O}$ was almost exclusively controlled by the ${ }^{18} \mathrm{O}$ signature of the $\mathrm{H}_{2} \mathrm{O}$. In line with this, Well and Flessa (2009) explained the relatively constant ${ }^{18} \mathrm{O}$ signature of $\mathrm{N}_{2} \mathrm{O}$ produced by denitrification in two soils by an almost complete $\mathrm{O}$ exchange with soil water.

We found increasing $\mathrm{O}$ exchange with increasing $\mathrm{N}_{2} \mathrm{O}$ production at a given $\mathrm{NO}_{2}{ }^{-}$supply. To interpret this observation, we propose a conceptual model of $\mathrm{O}$ exchange during fungal 
denitrification based on the models for bacterial denitrification proposed byAerssens et al. (1986), Casciotti et al. (2007) and Snider et al. (2013) (Figure 2):

Under natural conditions, the isotopic signature of $\mathrm{N}_{2} \mathrm{O}$ from fungal denitrification results from the isotopic enrichment factors of the reduction steps $\left(\varepsilon_{1}, \varepsilon_{2}\right.$ and $\left.\varepsilon_{3}\right)$, the fractions of $O$ exchange at the reduction step by $\operatorname{Nir}\left(x_{1}\right)$ and Nor $\left(x_{2}\right)$, and isotopic enrichment factors of $\mathrm{O}$ exchange ( $\varepsilon_{4}$ and $\varepsilon_{5}$ ) (Figure 2) (Casciotti et al., 2007; Snider et al., 2013). According to observations by Aerssens et al. (1986) $x_{1}$ is dependent on $\mathrm{NO}_{2}{ }^{-}$concentration. In our study, only the total $\mathrm{O}$ exchange with $\mathrm{H}_{2} \mathrm{O}$ (sum of $x_{1}$ and $x_{2}$ in the conceptual model, Figure 2) was determined. In comparison to the high ${ }^{18} \mathrm{O}$ enrichment of the medium water and subsequent incorporation of enriched $\mathrm{O}$ into $\mathrm{N}_{2} \mathrm{O}$, the isotope effects are very small. However, when applying the model of Snider et al. (2013) (calculated with Eq. 5 of Snider et al. (2013) with enriched $\mathrm{H}_{2} \mathrm{O}$ as precursor, the fractions of $\mathrm{O}$ exchange of this experiment and the isotope effects published by Casciotti et al. (2007) and Snider et al. (2013)., the bias of our tracer approach from the isotope effects $\varepsilon_{4}$ and $\varepsilon_{5}$ can be predicted. The impact of the isotope effects on $\delta^{18} \mathrm{O}-\mathrm{N}_{2} \mathrm{O}$ is largest, when full $\mathrm{O}$ exchange occurs at Nir. In that case the calculated $\mathrm{O}$ exchange can be overestimated by up to $2 \%$ if the isotope effect of $\mathrm{O}$ exchange is neglected as in our data analysis (Casciotti et al., 2007; Snider et al., 2013). This might influence the calculated values of $\mathrm{O}$ exchange and lead to values slightly above $100 \%$ as observed in few cases (see Table 1 and section "Calculations").

The $\mathrm{N}_{2} \mathrm{O}$ production rate reflects the abundance and activity of denitrification enzymes. Consequently, increasing $\mathrm{N}_{2} \mathrm{O}$ production causes a stronger local depletion of added $\mathrm{NO}_{2}{ }^{-}$, leading to an enhanced $\mathrm{O}$ exchange. Our data are in agreement with the proposed inverse relation between $\mathrm{NO}_{2}{ }^{-}$and $\mathrm{O}$ exchange in this conceptual model (Aerssens et al., 1986). Even though only a small fraction of added $\mathrm{NO}_{2}{ }^{-}$was consumed in the entire system (Table 1), there may have been a strong local depletion in $\mathrm{NO}_{2}{ }^{-}$, especially in the globose-type cultures, causing an increased $\mathrm{O}$ exchange compared to the turbid cultures. In soil experiments Snider et al. found that $\mathrm{O}$ exchange was independent of $\mathrm{N}_{2} \mathrm{O}$ production during denitrification and suggested that variations in $\mathrm{O}$ exchange between soils were dependent on the microbial soil community (Snider et al., 2009; Snider et al., 2013). Although the relation between $\mathrm{N}_{2} \mathrm{O}$ production and $\mathrm{O}$ exchange is different from our pure culture study, this observation does not necessarily contradict our conceptual model for several reasons. First, depletion in $\mathrm{NO}_{2}{ }^{-}$ concentration with higher $\mathrm{N}_{2} \mathrm{O}$ production is not expected in soil incubations if $\mathrm{NO}_{2}^{-}$is not added. Secondly, $\mathrm{N}_{2} \mathrm{O}$ was emitted from intact microbial soil communities, containing a vast number of different organisms with possibly different rates of $\mathrm{O}$ exchange. Finally, the 
proposed relation between $\mathrm{O}$ exchange and $\mathrm{NO}_{2}^{-}$is effective at the scale of individual microbial cells and might thus be completely masked when looking at bulk soil processes including heterogenic spatial distribution of microbial species and $\mathrm{N}$ processes.

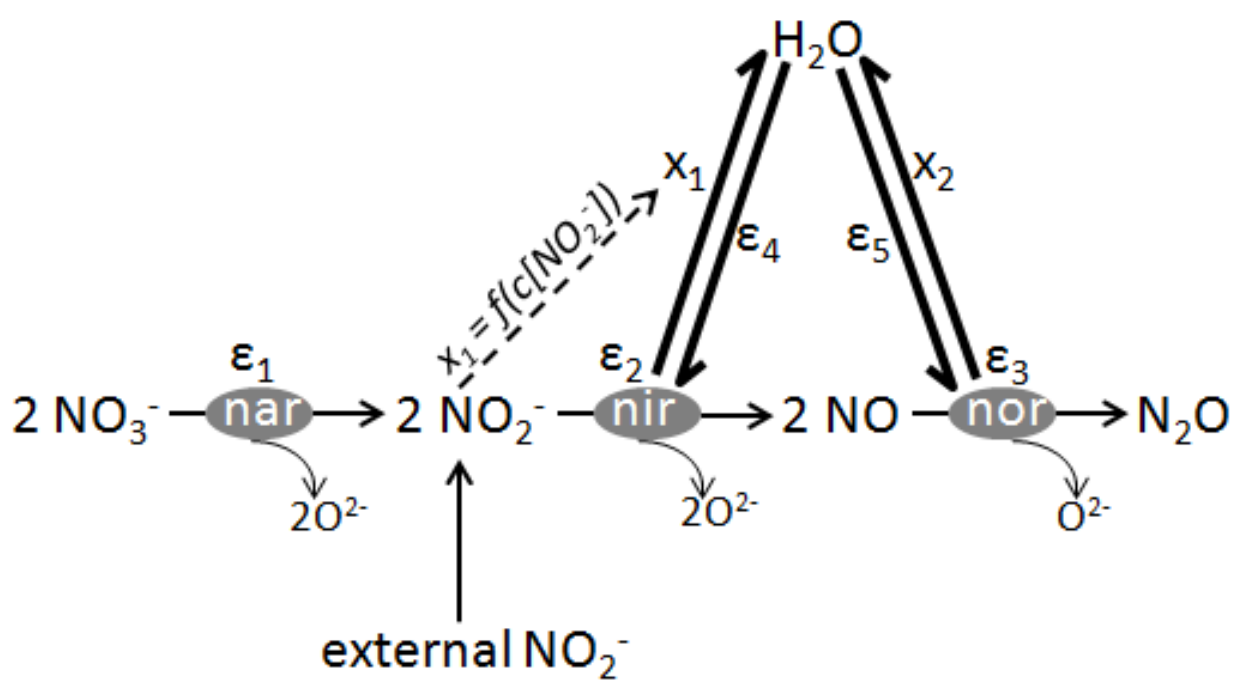

Figure 2: Conceptual model of intracellular $\mathrm{O}$ exchange and $\mathrm{O}$ isotope enrichment during fungal denitrification, adapted from previous concepts for bacterial denitrification after Casciotti et al. (2007) and Snider et al. (2013) (modified) and implementing controls of $\mathrm{O}$ exchange proposed by Aerssens et al. (1986) $\mathrm{N}_{2} \mathrm{O}$ consumption is assumed absent. The isotopic enrichment factors $(\varepsilon)$ are defined as the difference of the isotopic composition of the product and the substrate of a reaction (Snider et al., 2013). $\varepsilon_{1}$ and $\varepsilon_{2}$ describe the inter-molecular isotopic fractionation during $\mathrm{NO}_{3}{ }^{-}$reduction to $\mathrm{NO}_{2}{ }^{-}$or $\mathrm{NO}$ reduction to NO, respectively (Snider et al., 2013). Intra-molecular fractionation during $\mathrm{NO}_{3}{ }^{-}$or $\mathrm{NO}_{2}^{-}$reduction due to preferred cleavage of $\mathrm{N}^{16} \mathrm{O}$ bonds results in ${ }^{18} \mathrm{O}$-enriched $\mathrm{NO}_{2}^{-}$or $\mathrm{NO}$, respectively, and ${ }^{18} \mathrm{O}$-depleted $\mathrm{H}_{2} \mathrm{O}$ (Snider et al., 2013). $\varepsilon_{3}$ is the enrichment factor for the intermolecular isotopic effect during the reduction of $2 \mathrm{NO}$ to $\mathrm{N}_{2} \mathrm{O}$, resulting in ${ }^{18} \mathrm{O}$-enriched $\mathrm{N}_{2} \mathrm{O}$ and ${ }^{18} \mathrm{O}$-depleted $\mathrm{H}_{2} \mathrm{O}$ (Snider et al., 2013). The fractions of the $\mathrm{O}$ exchange between denitrification intermediates and water during $\mathrm{NO}_{2}^{-}$reduction by Nir and $\mathrm{NO}$ reduction by Nor are defined as $x_{1}$ and $\mathrm{x}_{2}$, respectively. For $x_{1}$ the extent of $\mathrm{O}$ exchange is a function of the $\mathrm{NO}_{2}^{-}$concentration $\left(c\left[\mathrm{NO}_{2}{ }^{-}\right]\right)$, according to observations by Aerssens et al. (1986). for bacteria containing the heme cd-1 Nir type ( $x_{1}$ $=f\left(c\left[\mathrm{NO}_{2}^{-}\right]\right.$) (indicated by dotted arrow) (Snider et al., 2013). External $\mathrm{NO}_{2}^{-}$sources (from other $\mathrm{N}$ processes or experimentally added) and the rates of $\mathrm{NO}_{2}{ }^{-}$reduction by Nar and its consumption by $\mathrm{Nir}$ controls $\mathrm{NO}_{2}{ }^{-}$concentration and thus indirectly $x_{l}$. The isotope enrichment factors during $\mathrm{O}$ exchange at the Nir and Nor reduction steps are $\varepsilon_{4}$ and $\varepsilon_{5}$, respectively (Snider et al., 2013).

It is striking that $C$. funicola, the only species of the order Sordariales, exhibited several exceptional results. It did not produce $\mathrm{N}_{2} \mathrm{O}$ in presence of $\mathrm{NO}_{3}{ }^{-}$and showed the smallest $\mathrm{N}_{2} \mathrm{O}$ production as well as the smallest $\mathrm{O}$ exchange during denitrification with $\mathrm{NO}_{2}^{-}$. The small $\mathrm{O}$ exchange might be specific for the enzyme structure of this order, a result that could be 
comparable to differing $\mathrm{O}$ exchanges between the two bacterial Nir types (heme-cd 1 and copper) found by Ye et al. (1991). Further studies are needed to verify order-specific effects and also order-specific process controls of $\mathrm{N}_{2} \mathrm{O}$ production as well as of $\mathrm{O}$ exchange.

What are the implications of the observed $\mathrm{O}$ exchange between $\mathrm{H}_{2} \mathrm{O}$ and denitrification intermediates? The observed variability in $\mathrm{O}$ exchange among soil communities and pure bacterial and fungal cultures demonstrates the high relevance of this process when interpreting the isotopic fingerprint of soil-derived $\mathrm{N}_{2} \mathrm{O}$ (Aerssens et al., 1986; Garber and Hollocher, 1982; Kool et al., 2011; Snider et al., 2009; Snider et al., 2013; Ye et al., 1991). Complete $\mathrm{O}$ exchange implies independence of the $\mathrm{O}$ signature of the precursor $\left(\mathrm{NO}_{2}{ }^{-}\right.$or $\mathrm{NO}_{3}{ }^{-}$). In that case, $\delta^{18} \mathrm{O}-\mathrm{N}_{2} \mathrm{O}$ would only be controlled by the $\mathrm{H}_{2} \mathrm{O}$ signature, isotopic fractionation of $\mathrm{O}$ exchange and the isotopic fractionation after $\mathrm{O}$ exchange during the $\mathrm{NO}_{2}{ }^{-}$ reduction to $\mathrm{N}_{2} \mathrm{O}$ (Kool et al., 2009b; Well et al., 2012). Our results suggest that $\mathrm{O}$ exchange by fungal denitrifers is similar to bacterial denitrifiers in two ways: (I) ranges are similar $(<10$ to $100 \%$ ) and (II) almost all $\mathrm{O}$ exchange rates of our pure fungal cultures and of incubated soils (Kool et al., 2009b; Snider et al., 2013) were between 65 and 100\%. These high O exchanges exclude the use of $\delta^{18} \mathrm{O}$-values to identify $\mathrm{N}_{2} \mathrm{O}$ precursors and pathways of $\mathrm{N}_{2} \mathrm{O}$ formation without quantifying $\mathrm{O}$ exchanges and prevent the differentiation between fungal and bacterial sources of $\mathrm{N}_{2} \mathrm{O}$ using ${ }^{18} \mathrm{O}$ signatures. Another consequence might be a small variability of $\delta^{18} \mathrm{O}-\mathrm{N}_{2} \mathrm{O}$ compared to $\delta^{18} \mathrm{O}$-values of denitrification precursors. This would facilitate the estimation of $\mathrm{N}_{2} \mathrm{O}$ reduction to $\mathrm{N}_{2}$ using $\delta^{18} \mathrm{O}$-values.

In view of the growing evidence on the role of fungal denitrification to $\mathrm{N}_{2} \mathrm{O}$ fluxes the missing distinction between fungal and bacterial $\mathrm{O}$ exchange rates is relevant since it illustrates that variations in the fungal share of soil $\mathrm{N}_{2} \mathrm{O}$ fluxes would not affect the extent of $\mathrm{O}$ incorporation from $\mathrm{H}_{2} \mathrm{O}$ (Blagodatskaya et al., 2010; Laughlin and Stevens, 2002; Long et al., 2013; McLain and Martens, 2006). Hence, the high $\mathrm{O}$ exchange during $\mathrm{N}_{2} \mathrm{O}$ formation in soil as suggested by previous soil studies is probably independent of the fungal-to-bacterial ratio of the $\mathrm{N}_{2} \mathrm{O}$ fluxes (Kool et al., 2009a; Kool et al., 2009b; Well and Flessa, 2009). However, since we could not clarify the mechanisms controlling fungal $\mathrm{O}$ exchange, more pure culture work is needed with defined manipulation of suspected controlling factors.

\section{Conclusions}

We found that $\mathrm{O}$ exchange between $\mathrm{H}_{2} \mathrm{O}$ and intermediates of denitrification exists in pure fungal cultures. Variation in the extent of $\mathrm{O}$ exchange might be explained by the interaction between $\mathrm{N}_{2} \mathrm{O}$ production rates and $\mathrm{NO}_{2}{ }^{-}$concentration. Further research is needed to estimate 
fungal $\mathrm{O}$ exchange under soil conditions, e.g., by varying the ratio between $\mathrm{NO}_{2}{ }^{-}$and fungal biomass. Our data indicate that the identification of $\mathrm{N}_{2} \mathrm{O}$ produced by fungi or bacteria based on $\delta^{18} \mathrm{O}-\mathrm{N}_{2} \mathrm{O}$ is not possible due to a similar range in $\mathrm{O}$ exchange by both organism groups. The suspected similarity of controlling factors during fungal and bacterial $\mathrm{O}$ exchange suggests that both microbial groups might yield an almost complete $\mathrm{O}$ exchange in soils, which would facilitate the estimation of $\mathrm{N}_{2} \mathrm{O}$ reduction based on $\delta^{18} \mathrm{O}$-values of emitted $\mathrm{N}_{2} \mathrm{O}$.

\section{$\underline{\text { Acknowledgement }}$}

Susanne Behn is thanked for assistance with microbial work and Martina Heuer for isotopic analysis; the Max-Planck Institute for Terrestrial Microbiology in Marburg (Germany) for providing the fungal strains and for the possibility to work in their lab, and Roland Fuß for help with statistical analysis. We would like to thank Dina Führmann for editing the English. Further thanks to the two anonymous referees for improving our manuscript by helpful and constructive suggestions. This joint research project was financially supported by the State of Lower-Saxony and the Volkswagen Foundation, Hanover, Germany.

\section{$\underline{\text { References }}$}

Aerssens, E., Tiedje, J.M., Averill, B.A., 1986. Isotope Labeling Studies on the Mechanisms of Nbond Formation in Denitrification. Journal of Biological Chemistry 261, 9652-9656.

Blagodatskaya, E., Dannenmann, M., Gasche, R., Butterbach-Bahl, K., 2010. Microclimate and forest management alter fungal-to-bacterial ratio and $\mathrm{N}_{2} \mathrm{O}$-emission during rewetting in the forest floor and mineral soil of mountainous beech forests. Biogeochemistry 97, 55-70.

Bollag, J.M., Tung, G., 1972. Nitrous oxide release by soil fungi. Soil Biology and Biochemistry 4, 271-276.

Brand, W.A., 1995. Precon: A Fully Automated Interface for the Pre-GC Cocentration of Trace Gases in Air for Isotopic Analysis. Isotopes in Environmental and Health Studies 31, 277 284.

Brunner, B., Bernasconi, S.M., Kleikemper, J., Schroth, M.H., 2005. A model for oxygen and sulfur isotope fractionation in sulfate during bacterial sulfate reduction processes. Geochimica et Cosmochimica Acta 69, 4773-4785.

Casciotti, K.L., Böhlke, J.K., Mcllvin, M.R., Mroczkowski, S.J., Hannon, J.E., 2007. Oxygen Isotopes in Nitrite: Analysis, Calibration, and Equilibration. Analytical Chemistry 79, 24272436.

Casciotti, K.L., Sigman, D.M., Hastings, M.G., Böhlke, J.K., Hilkert, A., 2002. Measurement of the Oxygen Isotopic Composition of Nitrate in Seawater and Freshwater Using the Denitrifier Method. Analytical Chemistry 74, 4905-4912.

Cleemput, O., Samater, A., 1995. Nitrite in soils: accumulation and role in the formation of gaseous N compounds. Fertilizer research 45, 81-89.

Davidson, E.A., Firestone, M.K., 1988. Measurement of Nitrous Oxide Dissolved in Soil Solution. Soil Science Society of America Journal 52, 1201-1203.

Domsch, K.H., Gams, W., Anderson, T.H., 1980. Compendium of soil fungi. Volumes 1 and 2. Academic Press Ltd., London, UK, vii + 859 pp. 
Garber, E.A., Hollocher, T.C., 1982. ${ }^{15} \mathrm{~N},{ }^{18} \mathrm{O}$ tracer studies on the activation of nitrite by denitrifying bacteria. Nitrite/water-oxygen exchange and nitrosation reactions as indicators of electrophilic catalysis. Journal of Biological Chemistry 257, 8091-8097.

IPCC, 2007. Climate Change 2007 - The Physical Science Basis: Working Group I Contribution to the Fourth Assessment Report of the IPCC. Cambridge University Press.

Kim, S.W., Fushinobu, S., Zhou, S.M., Wakagi, T., Shoun, H., 2009. Eukaryotic nirK Genes Encoding Copper-Containing Nitrite Reductase: Originating from the Protomitochondrion? Applied and Environmental Microbiology 75, 2652-2658.

Knöller, K., Vogt, C., Haupt, M., Feisthauer, S., Richnow, H.-H., 2011. Experimental investigation of nitrogen and oxygen isotope fractionation in nitrate and nitrite during denitrification. Biogeochemistry 103, 371-384.

Knowles, R., 1982. Denitrification. Microbiological Reviews 46, 43-70.

Kool, D.M., Müller, C., Wrage, N., Oenema, O., Van Groenigen, J.W., 2009a. Oxygen exchange between nitrogen oxides and $\mathrm{H}_{2} \mathrm{O}$ can occur during nitrifier pathways. Soil Biology and Biochemistry 41, 1632-1641.

Kool, D.M., Van Groenigen, J.W., Wrage, N., 2011. Source dertermination of Nitrous Oxide based on Nitrogen and Oxygen Isotopes tracing: Dealing with Oxygen Exchange, In: Klotz, M.G., Stein, L.Y. (Eds.), Methods in Enzymology, Vol 46: Research on Nitrification and Related Processes, Pt B, pp. 139-160.

Kool, D.M., Wrage, N., Oenema, O., Dolfing, J., Van Groenigen, J.W., 2007. Oxygen exchange between (de)nitrification intermediates and $\mathrm{H}_{2} \mathrm{O}$ and its implications for source determination of $\mathrm{NO}_{3}{ }^{-}$and $\mathrm{N}_{2} \mathrm{O}$ : a review. Rapid Communications in Mass Spectrometry 21, 3569-3578.

Kool, D.M., Wrage, N., Oenema, O., Harris, D., Van Groenigen, J.W., 2009b. The ${ }^{18}$ O signature of biogenic nitrous oxide is determined by $\mathrm{O}$ exchange with water. Rapid Communications in Mass Spectrometry 23, 104-108.

Köster, J.R., Well, R., Tuzson, B., Bol, R., Dittert, K., Giesemann, A., Emmenegger, L., Manninen, A., Cárdenas, L., Mohn, J., 2013. Novel laser spectroscopic technique for continuous analysis of $\mathrm{N}_{2} \mathrm{O}$ isotopomers - application and intercomparison with isotope ratio mass spectrometry. Rapid Communications in Mass Spectrometry 27, 216-222.

Laughlin, R.J., Stevens, R.J., 2002. Evidence for Fungal Dominance of Denitrification and Codenitrification in a Grassland Soil. Soil Science Society of America Journal 66, 15401548.

Long, A., Heitman, J., Tobias, C., Philips, R., Song, B., 2013. Co-Occurring Anammox, Denitrification, and Codenitrification in Agricultural Soils. Applied and Environmental Microbiology 79, 168-176.

McLain, J.E.T., Martens, D.A., 2006. $\mathrm{N}_{2} \mathrm{O}$ production by heterotrophic $\mathrm{N}$ transformations in a semiarid soil. Applied Soil Ecology 32, 253-263.

Morozkina, E.V., Kurakov, A.V., 2007. Dissimilatory nitrate reduction in fungi under conditions of hypoxia and anoxia: A review. Applied Biochemistry and Microbiology 43, 544-549.

Ostrom, N., Ostrom, P., 2011. The Isotopomers of Nitrous Oxide: Analytical Considerations and Application to Resolution of Microbial Production Pathways, In: Baskaran, M. (Ed.), Handbook of Environmental Isotope Geochemistry. Springer Berlin Heidelberg, pp. 453476.

Shearer, G., Kohl, D.H., 1988. Nitrogen isotopic fractionation and ${ }^{18} \mathrm{O}$ exchange in relation to the mechanism of denitrification of nitrite by Pseudomonas stutzeri. Journal of Biological Chemistry 263, 13231-13245.

Shoun, H., Fushinobu, S., Jiang, L., Kim, S.W., Wakagi, T., 2012. Fungal denitrification and nitric oxide reductase cytochrome P450nor. Philosophical Transactions of the Royal Society BBiological Sciences 367, 1186-1194. 
Shoun, H., Kim, D.-H., Uchiyama, H., Sugiyama, J., 1992. Denitrification by fungi. FEMS Microbiology Letters 94, 277-281.

Snider, D.M., Schiff, S.L., Spoelstra, J., 2009. ${ }^{15} \mathrm{~N} /{ }^{14} \mathrm{~N}$ and ${ }^{18} \mathrm{O} /{ }^{16} \mathrm{O}$ stable isotope ratios of nitrous oxide produced during denitrification in temperate forest soils. Geochimica et Cosmochimica Acta 73, 877-888.

Snider, D.M., Venkiteswaran, J.J., Schiff, S.L., Spoelstra, J., 2012. Deciphering the oxygen isotope composition of nitrous oxide produced by nitrification. Global Change Biology 18, 356-370.

Snider, D.M., Venkiteswaran, J.J., Schiff, S.L., Spoelstra, J., 2013. A new mechanistic model of $\delta^{18} \mathrm{O}-\mathrm{N}_{2} \mathrm{O}$ formation by denitrification. Geochimica et Cosmochimica Acta 112, 102-115.

Takaya, N., Kuwazaki, S., Adachi, Y., Suzuki, S., Kikuchi, T., Nakamura, H., Shiro, Y., Shoun, H., 2003. Hybrid respiration in the denitrifying mitochondria of Fusarium oxysporum. Journal of Biochemistry 133, 461-465.

Toyoda, S., Yoshida, N., 1999. Determination of nitrogen isotopomers of nitrous oxide on a modified isotope ratio mass spectrometer. Analytical Chemistry 71, 4711-4718.

Well, R., Eschenbach, W., Flessa, H., von der Heide, C., Weymann, D., 2012. Are dual isotope and isotopomer ratios of $\mathrm{N}_{2} \mathrm{O}$ useful indicators for $\mathrm{N}_{2} \mathrm{O}$ turnover during denitrification in nitratecontaminated aquifers? Geochimica et Cosmochimica Acta 90, 265-282.

Well, R., Flessa, H., 2009. Isotopologue signatures of $\mathrm{N}_{2} \mathrm{O}$ produced by denitrification in soils. Journal of Geophysical Research: Biogeosciences 114, G02020.

Wrage, N., van Groenigen, J.W., Oenema, O., Baggs, E.M., 2005. A novel dual-isotope labelling method for distinguishing between soil sources of $\mathrm{N}_{2} \mathrm{O}$. Rapid Communications in Mass Spectrometry 19, 3298-3306.

Ye, R.W., Toro-Suarez, I., Tiedje, J.M., Averill, B.A., 1991. $\mathrm{H}_{2}{ }^{18} \mathrm{O}$ isotope exchange studies on the mechanism of reduction of nitric oxide and nitrite to nitrous oxide by denitrifying bacteria. Evidence for an electrophilic nitrosyl during reduction of nitric oxide. Journal of Biological Chemistry 266, 12848-12851. 
Chapter 3

\section{Dual isotope and isotopomer signatures of nitrous oxide from fungal denitrification - a pure culture study}

This chapter is a modified form of an article, which was in the reviewing process of the journal Rapid Communications in Mass Spectrometry when the thesis was submitted. After the submission of the thesis the article was published in a revised version (DOI:10.1002/rcm.6975):

Rohe, L., Anderson, T.-H., Braker, G., Flessa, H., Giesemann, A., Lewicka-Szczebak D., Wrage-Mönnig, N. and Well, R. (2014). Dual isotope and isotopomer signatures of nitrous oxide from fungal denitrification - a pure culture study

\section{$\underline{\text { Abstract }}$}

RATIONALE: The contribution of fungal denitrification to the emission of the greenhouse gas nitrous oxide $\left(\mathrm{N}_{2} \mathrm{O}\right)$ from soil has not yet been sufficiently investigated. The intramolecular ${ }^{15} \mathrm{~N}$ site preference (SP) of $\mathrm{N}_{2} \mathrm{O}$ could provide a tool to distinguish between $\mathrm{N}_{2} \mathrm{O}$ produced by bacteria or fungi, since fungi showed much higher $\mathrm{SP}$ of $\mathrm{N}_{2} \mathrm{O}$ in previous studies than bacteria.

METHODS: To further constrain isotopic evidence of fungal denitrification, we incubated six soil fungal strains under denitrifying conditions, either with the electron acceptor nitrate or nitrite, and analyzed the isotopic signature $\left(\delta^{18} \mathrm{O}, \delta^{15} \mathrm{~N}_{\text {bulk }}\right.$ and SP) of $\mathrm{N}_{2} \mathrm{O}$ produced. Nitrogen and oxygen isotopic fractionation was calculated and oxygen isotope exchange associated with particular fungal enzymes was estimated.

RESULTS: Five fungi of the order Hypocreales produced $\mathrm{N}_{2} \mathrm{O}$ with a SP of $31.7 \pm 1.4 \%$ after seven days of anaerobic incubation independent of the electron acceptor, whereas one Sordariales species produced $\mathrm{N}_{2} \mathrm{O}$ from $\mathrm{NO}_{2}{ }^{-}$only, with a SP of $19.7 \pm 1.3 \%$. Smaller isotope effects of ${ }^{15} \mathrm{~N}_{\text {bulk }}$ were associated with larger $\mathrm{N}_{2} \mathrm{O}$ production. The $\delta^{18} \mathrm{O}$ values were influenced by oxygen exchange between water and denitrification intermediates, which occurred predominantly at nitrite reductase.

CONCLUSIONS: Our results confirm that SP is a promising tool to differentiate between fungal and bacterial $\mathrm{N}_{2} \mathrm{O}$ from denitrification. Modelling of ${ }^{18} \mathrm{O}$ fractionation processes indicated different mechanisms of the oxygen exchange for various fungal species studied. However, more information is needed about different groups of fungi as they may differ in fungal denitrification and SP.

KEYWORDS: Fungi, $\mathrm{N}_{2} \mathrm{O}$ isotopologues, Isotopic fractionation, Oxygen exchange, Site preference 


\section{$\underline{\text { Introduction }}$}

Agricultural soils are the most important anthropogenic source of the greenhouse gas nitrous oxide $\left(\mathrm{N}_{2} \mathrm{O}\right)$ and contribute to the rising $\mathrm{N}_{2} \mathrm{O}$ concentration in the atmosphere (IPCC, 2013). Finding mitigation strategies for $\mathrm{N}_{2} \mathrm{O}$ emissions is important, and for this purpose better knowledge of the controls of $\mathrm{N}_{2} \mathrm{O}$ fluxes are urgently needed.

One of the main pathways producing $\mathrm{N}_{2} \mathrm{O}$ is denitrification, the reduction of nitrate $\left(\mathrm{NO}_{3}{ }^{-}\right)$to nitrite $\left(\mathrm{NO}_{2}{ }^{-}\right)$and to gaseous dinitrogen $\left(\mathrm{N}_{2}\right)$ via the gaseous intermediates nitric oxide (NO) and $\mathrm{N}_{2} \mathrm{O}$ under anaerobic conditions (Knowles, 1982). In the 1970s, it was shown that in addition to bacteria, fungi are capable of denitrification and $\mathrm{N}_{2} \mathrm{O}$ production (Bollag and Tung, 1972). Since then a number of pure culture studies on fungal denitrification were published (Bollag and Tung, 1972; Shoun et al., 1992; Shoun and Tanimoto, 1991; Sutka et al., 2008). Of particular importance was the finding of Shoun et al. (1992), that most fungi lack the enzyme $\mathrm{N}_{2} \mathrm{O}$ reductase (Nos), hence most fungi produce $\mathrm{N}_{2} \mathrm{O}$ as the major end product of fungal denitrification. Referring to this, Sutka et al. (2008) hypothesized that in soils the lack of Nos enables fungi to potentially produce more $\mathrm{N}_{2} \mathrm{O}$ than bacteria, given the assumption that both groups have identical or similar denitrification rates, and given that relative to bacteria, fungal biomass is much more abundant in most soils (up to $96 \%$ of biomass) (Braker and Conrad, 2011; Ruzicka et al., 2000).

Several laboratory studies with soils indicated that fungi compared to bacteria dominated $\mathrm{N}_{2} \mathrm{O}$ production by denitrification (Blagodatskaya et al., 2010; Crenshaw et al., 2008; Laughlin and Stevens, 2002; Long et al., 2013; McLain and Martens, 2006). Commonly, antibiotic inhibitors of either fungal or bacterial growth are used to differentiate between $\mathrm{N}_{2} \mathrm{O}$ produced by both microbial groups (Blagodatskaya et al., 2010; Crenshaw et al., 2008; Laughlin and Stevens, 2002; Long et al., 2013; McLain and Martens, 2006). However, there are organisms, which are not affected by the growth inhibitors and growth inhibitors do not affect active microorganisms that are not in growth stage. $\mathrm{N}_{2} \mathrm{O}$ produced by this group may influence results of these experiments. Furthermore, the inhibition of growth may affect processes other than just the target processes. A direct method to differentiate between the production of $\mathrm{N}_{2} \mathrm{O}$ by fungal and bacterial denitrification is not yet available. Studies to analyze the enzymes involved in denitrification identified only the NO reductase (Nor) of fungi (P450nor) as distinct from its bacterial counterpart, while all other enzymes involved in fungal denitrification were similar to the bacterial ones (Kim et al., 2009).

Measuring the dual isotopic composition of $\mathrm{N}_{2} \mathrm{O}\left(\delta^{15} \mathrm{~N}_{\text {bulk }}\right.$ and $\left.\delta^{18} \mathrm{O}\right)$ has become a useful tool for advancing our knowledge of $\mathrm{N}_{2} \mathrm{O}$ production pathways and sources (Kool et al., 2011; 
Ostrom and Ostrom, 2011; Wrage et al., 2005). Isotopic fractionation affects $\delta^{15} \mathrm{~N}_{\text {bulk }}$ and $\delta^{18} \mathrm{O}$ values of $\mathrm{N}_{2} \mathrm{O}$. Hence, during denitrification theoretical fractionation results in the production of $\mathrm{N}_{2} \mathrm{O}$ with decreased $\delta^{15} \mathrm{~N}_{\text {bulk }}$ and $\delta^{18} \mathrm{O}$ values compared to the precursors while concurrent $\mathrm{N}_{2} \mathrm{O}$ reduction results in residual $\mathrm{N}_{2} \mathrm{O}$ that comprises comparatively increased $\delta^{15} \mathrm{~N}_{\text {bulk }}$ and $\delta^{18} \mathrm{O}$ values compared to $\mathrm{N}_{2} \mathrm{O}$ produced without influences of $\mathrm{N}_{2} \mathrm{O}$ reduction (Ostrom and Ostrom, 2011; Toyoda et al., 2005). Oxygen (O) isotopes are additionally affected by $\mathrm{O}$ exchange between water $\left(\mathrm{H}_{2} \mathrm{O}\right)$ and denitrification intermediates (Aerssens et al., 1986; Casciotti et al., 2002; Garber and Hollocher, 1982; Kool et al., 2009; Rohe et al., 2014; Ye et al., 1991). Consequently, isotopic fractionation and O exchange during denitrification affects the isotopic composition of $\mathrm{N}_{2} \mathrm{O}$ and thus has to be taken into account when interpreting isotopic data of emitted $\mathrm{N}_{2} \mathrm{O}$. The intramolecular ${ }^{15} \mathrm{~N}$ site preference of $\mathrm{N}_{2} \mathrm{O}$ (SP), which is the difference between the $\delta^{15} \mathrm{~N}$ value of the central and terminal $\mathrm{N}$ position of the asymmetric $\mathrm{N}_{2} \mathrm{O}$ molecule, may be a prospective possibility to distinguish between $\mathrm{N}_{2} \mathrm{O}$ produced by bacteria or fungi (Toyoda et al., 2005). The SP of $\mathrm{N}_{2} \mathrm{O}$ produced by several bacterial strains ranged from -11 to 0 \%o (Frame and Casciotti, 2010; Sutka et al., 2006), whereas the two fungal strains analyzed so far (Fusarium oxysporum and Cylindrocarpon tonkinense) produced $\mathrm{N}_{2} \mathrm{O}$ with a SP of $37 \%$ (Sutka et al., 2008). Differences in SP between fungal and bacterial $\mathrm{N}_{2} \mathrm{O}$ can be explained by enzyme structures, suggesting sequential binding of two $\mathrm{NO}$ molecules during $\mathrm{N}_{2} \mathrm{O}$ formation in the fungal P450nor, whereas a parallel binding mechanism is assumed in bacterial Nors (Schmidt et al., 2004). During denitrification SP is independent of the isotopic composition of the $\mathrm{N}_{2} \mathrm{O}$ precursors (Toyoda et al., 2002). but it might reflect the microbial source of $\mathrm{N}_{2} \mathrm{O}$. Hence, assuming that the current pure culture data are representative for most fungal and bacterial species under natural soil conditions, differences in SP might be used to quantify the contribution to $\mathrm{N}_{2} \mathrm{O}$ emission from denitrification of microbial groups in a mixed soil community. If $\mathrm{N}_{2} \mathrm{O}$ production pathways can be determined and clearly attributed to either nitrification or denitrification, and the contribution of the different microbial groups can be quantified, this would contribute to better understanding and prediction of soil $\mathrm{N}_{2} \mathrm{O}$ fluxes and thus facilitate developing mitigation measures (Richardson et al., 2009).

However, up-to-date information on isotopic fractionation during $\mathrm{N}_{2} \mathrm{O}$ production by fungal denitrifiers and the resulting $\mathrm{SP}$ of $\mathrm{N}_{2} \mathrm{O}$ is scarce and more data is necessary to improve methods for a reliable quantification of bacterial and fungal contribution to $\mathrm{N}_{2} \mathrm{O}$ emissions from the soil community. Therefore, to further constrain isotope effects of fungal denitrification, we incubated six fungal species including those used by Sutka et al. (2008) 
under denitrifying conditions, either with $\mathrm{NO}_{3}{ }^{-}$or $\mathrm{NO}_{2}{ }^{-}$as electron acceptor, and analyzed the isotopologues of $\mathrm{N}_{2} \mathrm{O}$ produced $\left(\delta^{18} \mathrm{O}, \delta^{15} \mathrm{~N}_{\text {bulk }}, \mathrm{SP}\right)$.

\section{Materials and Methods}

\section{Microorganisms}

For isotopologue analysis of $\mathrm{N}_{2} \mathrm{O}$ from fungal denitrification, we used six fungal species that are found in soils, described in Domsch et al. (1980) (Table 1). In experiments by Sutka et al. (2008), $\mathrm{N}_{2} \mathrm{O}$ produced by $C$. lichenicola (synonymous name $C$. tonkinense, Nite Biological Research Center, Chiba, Japan) and F. oxysporum was measured to analyze the SP of $\mathrm{N}_{2} \mathrm{O}$ from denitrification, but the authors used different strains (ATCC 42055 and ATCC 12581) thus enabling us to evaluate whether different strains from the same species produce identical SP of $\mathrm{N}_{2} \mathrm{O}$ (Sutka et al., 2008). Accumulation of $\mathrm{N}_{2} \mathrm{O}$ during incubations is assumed to represent $\mathrm{N}_{2} \mathrm{O}$ production because $\mathrm{N}_{2} \mathrm{O}$ reduction has been found to be negligible for fungi, with no detectable $\mathrm{N}_{2}$ production by $F$. oxysporum and $F$. decemcellulare, while the other fungi produced only a small $\mathrm{N}_{2}$ amount compared to bacteria capable of $\mathrm{N}_{2} \mathrm{O}$ reduction (Shoun et al., 1992). Although Shoun et al. (1992) found indications by ${ }^{15} \mathrm{~N}$ tracer application, that fungal codenitrification might have occurred, the contribution was minimal and thus we assume that codenitrification in our incubation played a negligible role.

Table 1: Fungal species in incubation experiments to determine isotopic composition of $\mathrm{N}_{2} \mathrm{O}$ from denitrification.

\begin{tabular}{|c|c|c|}
\hline Fungal species & $\begin{array}{l}\text { Catalogue } \\
\text { number }^{\mathrm{a}}\end{array}$ & $\begin{array}{l}\text { Biological } \\
\text { order }\end{array}$ \\
\hline Chaetomium funicola & JCM 22733 & Sordariales \\
\hline Fusarium oxysporum & JCM 11502 & Hypocreales \\
\hline Trichoderma hamatum & JCM 1875 & Hypocreales \\
\hline Cylindrocarpon lichenicola & NBRC 30561 & Hypocreales \\
\hline Fusarium solani fsp. pisi & NBRC 9425 & Hypocreales \\
\hline Fusarium decemcellulare & NBRC 31657 & Hypocreales \\
\hline
\end{tabular}




\section{Experimental procedure}

We conducted experiments to determine dual isotope and isotopomer effects during $\mathrm{N}_{2} \mathrm{O}$ production by fungal denitrification using pure culture incubation procedures according to the protocol of previous studies (Rohe et al., 2014; Shoun et al., 1992): The sterile fungal medium for the preparatory culture $(100 \mathrm{~mL})$ contained $1 \%$ glucose, $0.2 \%$ peptone, $0.02 \% \mathrm{MgSO}_{4} \cdot 7$ $\mathrm{H}_{2} \mathrm{O}, 2 \mathrm{ppm} \mathrm{CaCl}_{2} \cdot 6 \mathrm{H}_{2} \mathrm{O}, 2 \mathrm{ppm} \mathrm{FeSO}_{4} \cdot 7 \mathrm{H}_{2} \mathrm{O}$ and 0.01 mol potassium phosphate (pH 7.4) (Shoun et al., 1992).

We used two Setups each differing in the volumes used with three fungal species. Initially, three fungi (Setup A) were incubated in a relatively large amount of medium ( $1 \mathrm{~L}$ flasks) to ensure enough $\mathrm{N}_{2} \mathrm{O}$ production for gas analysis. Because all three fungi produced far more $\mathrm{N}_{2} \mathrm{O}$ than needed, further incubations were conducted with smaller volumes (Setup B) to save preparation time and resources. In Setup A, the stem cultures of C. lichenicola, F. solani fsp. pisi and $F$. decemcellulare were transferred to $500 \mathrm{~mL}$ medium and incubated aerobically at $22{ }^{\circ} \mathrm{C}$ in the dark in a rotary shaker $(100 \mathrm{rpm})$ in a $1 \mathrm{~L}$ Erlenmeyer flask with cotton wool plugs for three to seven days (depending on the growth increase of the cells). Of this preculture, $60 \mathrm{~mL}$ were transferred in a $1 \mathrm{~L}$ flask with screw caps and a butyl stopper containing fresh medium (240 mL each). In Setup B, the stem cultures of C. funicola, $F$. oxysporum and T. hamatum were transferred to $100 \mathrm{~mL}$ medium and incubated aerobically at $22{ }^{\circ} \mathrm{C}$ in the dark in a rotary shaker (100 rpm) in a $250 \mathrm{~mL}$ Erlenmeyer flask with cotton wool plugs for three to seven days (depending on the growth increase of the cells). Of this pre-culture, $10 \mathrm{~mL}$ aliquots were transferred into a $120 \mathrm{~mL}$ crimp seal flask with a butyl stopper containing fresh medium (40 mL each).

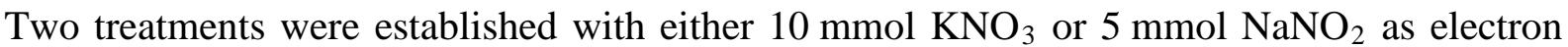
acceptors. All treatments were conducted in triplicate. The headspace of the flasks was purged with filter-sterilized $\mathrm{N}_{2}$ for 10 min while the flasks were stirred manually to expel dissolved $\mathrm{O}$ to establish anaerobic conditions. The cultures were incubated in the dark $\left(22{ }^{\circ} \mathrm{C}\right)$ in a rotary shaker (120 rpm). Gas samples were collected $(2 \times 14 \mathrm{~mL})$ after seven days of incubation and transferred with a syringe to evacuated sampling vials $\left(12 \mathrm{~mL}\right.$ Exetainer ${ }^{\circledR}$, Labco Ltd., Lampeter, UK). Due to the suggested absence of $\mathrm{N}_{2} \mathrm{O}$ reduction we expect consistent SP with time. The supply of electron acceptors $\mathrm{NO}_{3}{ }^{-}$and $\mathrm{NO}_{2}{ }^{-}$was much higher than their expected consumption and thus we assume no influence of substrate limitation or isotopic enrichment of substrates on isotopic signatures during the incubation.

To test for chemical production of $\mathrm{N}_{2} \mathrm{O}$, triplicates of $50 \mathrm{~mL}$ fresh medium containing either $10 \mathrm{mmol} \mathrm{KNO}_{3}{ }^{-}$or $5 \mathrm{mmol} \mathrm{NaNO}_{2}^{-}$were incubated, without inoculating with fungal pure 
cultures, using the same protocol as above for seven days. No bacterial or fungal growth could be observed by visual inspection after seven days of incubation, and the controls showed $\mathrm{N}_{2} \mathrm{O}$ production only in the presence of $\mathrm{NO}_{2}{ }^{-}$as electron acceptor $\left(<0.01 \mathrm{nmol} \mathrm{h}^{-1}\right)$, while no $\mathrm{N}_{2} \mathrm{O}$ production was detectable with $\mathrm{NO}_{3}{ }^{-}$.

To assess the biomass of each flask, the complete medium was centrifuged (5236 $\mathrm{x} g$ for $30 \mathrm{~min}$ ) at the end of incubation and the pellet was washed twice with distilled $\mathrm{H}_{2} \mathrm{O}$. The supernatant was decanted and the cells were oven dried at $105{ }^{\circ} \mathrm{C}$ for 48 hours to determine the dry weight of the fungal biomass. As the fungal biomass differed among species, $\mathrm{N}_{2} \mathrm{O}$ production was related to dry weight (dw) of the fungal biomass.

\section{Analysis of gas samples}

Headspace samples were analyzed by gas chromatography (GC, Agilent 7890A, Agilent, Böblingen, Germany) for $\mathrm{N}_{2} \mathrm{O}$ concentration. The detection limit of GC analysis of our incubation was $0.01 \mathrm{nmol} \mathrm{h}^{-1}$ with a measurement precision of $1 \%$. Dissolved $\mathrm{N}_{2} \mathrm{O}$ in the medium was calculated by Henry's law (Davidson and Firestone, 1988). In the following, the $\mathrm{N}_{2} \mathrm{O}$ production implies gas produced in the headspace as well as the calculated dissolved $\mathrm{N}_{2} \mathrm{O}$. Afterwards, samples were analyzed for $\mathrm{N}_{2} \mathrm{O}$ isotopologues by isotope ratio mass spectrometry (IRMS, Thermo Fisher Scientific, Bremen, Germany) using a pre-concentrator (PreCon, Thermo-Finnigan, Bremen, Germany) interfaced to Delta V isotope ratio mass spectrometer (Brand, 1995; Köster et al., 2013; Toyoda and Yoshida, 1999). The typical analytical accuracy $(1 \sigma)$ was $0.1 \%$ and $0.2 \%$ and $1.5 \%$ for $\delta^{15} \mathrm{~N}_{\text {bulk }}, \delta^{18} \mathrm{O}$ and SP, respectively.

\section{Isotope analysis of $\mathrm{NO}_{3}{ }^{-}, \mathrm{NO}_{2}{ }^{-}$and $\mathrm{H}_{2} \mathrm{O}$}

We used the bacterial denitrifier method according to Casciotti et al. (2002) to determine $\delta^{18} \mathrm{O}$ and $\delta^{15} \mathrm{~N}_{\text {bulk }}$ values of $\mathrm{NO}_{3}{ }^{-}$or $\mathrm{NO}_{2}{ }^{-}$in the media. The working standards for this method were USGS34, USGS35 and IAEA-No3. The $\mathrm{NO}_{2}{ }^{-}$had a $\delta^{18} \mathrm{O}$ of $-22.4 \pm 0.5 \%$ (vs. SMOW) and a $\delta^{15} \mathrm{~N}_{\text {bulk }}$ of $-22.7 \pm 0.1 \%$ (vs. air- $\mathrm{N}_{2}$ ) and $\mathrm{NO}_{3}{ }^{-}$had a $\delta^{18} \mathrm{O}$ of $22.0 \pm 0.3 \%$ (vs. SMOW) and a $\delta^{15} \mathrm{~N}_{\text {bulk }}$ of $1.4 \pm 0.3 \%$ o (vs. air- $\mathrm{N}_{2}$ ). The isotopic composition of the $\mathrm{H}_{2} \mathrm{O}$ in the fungal medium with Cy. lichenicola, F. decemcellulare and F. solani fsp. pisi was analyzed using a thermal combustion elemental analyzer (TC/EA-ConFlo III, Thermo Fisher, 
Bremen) coupled to IRMS (Delta plus, Thermo-Finnigan, Bremen) giving $-9.9 \pm 0.1 \%$ for $\delta^{18} \mathrm{O}$ (Centre for Stable Isotope Research and Analysis, University of Göttingen, Germany). The isotopic composition of $\mathrm{H}_{2} \mathrm{O}$ in the fungal medium with $F$. oxysporum, T. hamatum and C. funicola was analyzed using a cavity ring-down laser spectrometer (model L 1115-I, Picarro, Santa Clara, USA) giving $-8.9 \pm 0.2 \%$ for $\delta^{18} \mathrm{O}$.

\section{Calculations}

The estimation of the isotope fractionation during a unidirectional reaction can be expressed as the kinetic fractionation factor $\alpha$ (Kendall, 1998; Mariotti et al., 1982), which is defined as

$\alpha=\frac{\mathrm{R}_{\mathrm{P}}}{\mathrm{R}_{\mathrm{S}}}$

with $R_{P}$ and $R_{S}$ describing the isotope ratios of the product and the substrate, respectively.

The isotope enrichment factor $\varepsilon_{P / S}$ is defined as

$\varepsilon_{\mathrm{P} / \mathrm{S}}(\%)=1000 \times(\alpha-1)$

The reaction progress of fungal denitrification can be expressed as

Reaction progress $(\%)=\frac{\text { final } N_{2} O-N}{\text { initial } N O x-N} * 100$

with final $\mathrm{N}_{2} \mathrm{O}-\mathrm{N}$ describing the $\mathrm{N}_{2} \mathrm{O}-\mathrm{N}$ production and the initial $\mathrm{NO}_{x}-\mathrm{N}$ describing the precursor amount added.

The reaction progress in our incubations was small, i.e., only a small portion of the initial $\mathrm{N}$ substrates was consumed (Table 2). Thus, we could assume that the change in the isotopic composition of the precursors $\left(\mathrm{NO}_{2}{ }^{-}\right.$and $\left.\mathrm{NO}_{3}{ }^{-}\right)$of $\mathrm{N}_{2} \mathrm{O}$ would be negligible. Therefore, $\varepsilon_{P / S}$ can be approximated as follows, assuming that isotopic signature of the residual substrates is unaffected by fractionation

$\varepsilon_{P / S}(\%) \approx \delta p-\delta s=\Delta \delta$

with $\delta_{p}$ for the isotopic signature of the product $\left(\mathrm{N}_{2} \mathrm{O}\right)$ and $\delta_{s}$ for the isotopic signature of the substrate $\left(\mathrm{NO}_{2}{ }^{-}\right.$or $\left.\mathrm{NO}_{3}{ }^{-}\right)$, respectively.

The $\delta^{18} \mathrm{O}$ value of $\mathrm{N}_{2} \mathrm{O}\left(\delta^{18} \mathrm{O}-\mathrm{N}_{2} \mathrm{O}\right)$ produced by denitrification is affected by isotopic fractionation and by $\mathrm{O}$ exchange between denitrification intermediates and $\mathrm{H}_{2} \mathrm{O}$, which has to be taken into account, when interpreting the $\delta^{18} \mathrm{O}-\mathrm{N}_{2} \mathrm{O}$ values (Kool et al., 2009; Rohe et al., 2014). Therefore, the $\Delta \delta^{18} \mathrm{O}$ value cannot be determined in a straight-forward way. 


\section{Statistical analysis}

The $\mathrm{N}_{2} \mathrm{O}$ production was calculated per dry weight (dw) of fungal biomass and $\log _{10^{-}}$ transformed to achieve normality and homogeneity of variance of the residuals. The negative $\Delta \delta^{15} \mathrm{~N}_{\text {bulk }}$ values had to be converted into positive numbers by multiplying by (-1) to be able to $\log _{10}$-transform the $\Delta \delta^{15} \mathrm{~N}_{\text {bulk }}$ for the same reasons as for $\mathrm{N}_{2} \mathrm{O}$ production. We conducted three ANOVAs to test the effect of fungal species, the structure of fungal cultures and electron acceptors on $\mathrm{N}_{2} \mathrm{O}$ production, SP and $\Delta \delta^{15} \mathrm{~N}_{\text {bulk. }}$. For all ANOVAs, C. funicola had to be excluded, because it only produced $\mathrm{N}_{2} \mathrm{O}$ with $\mathrm{NO}_{2}{ }^{-}$and therefore an electron acceptor effect cannot be determined. Nevertheless, we tested if SP of $\mathrm{N}_{2} \mathrm{O}$ with $\mathrm{NO}_{2}{ }^{-}$as electron acceptor differed among all six fungal species including $C$. funicola with an ANOVA. A pairwise comparison with Tukey's HSD test was done to find differences between species influencing the SP of $\mathrm{N}_{2} \mathrm{O}$ produced. The significance level $\alpha$ was 0.05 . We calculated a linear regression of the calculated $\Delta \delta^{15} \mathrm{~N}_{\text {bulk }}$ and the $\log _{10}$-transformed $\mathrm{N}_{2} \mathrm{O}$ production after seven days of incubation (with $\mathrm{NO}_{3}{ }^{-}$and $\mathrm{NO}_{2}{ }^{-}$) by six different fungal species with a 95\% confidence interval. For statistical analyses, we used the program R (R Core Team, 2013).

\section{$\underline{\text { Results }}$}

\section{Evidence of fungal growth}

The visible growth structure differed among species. While all other species showed globose growth (with or without turbidity), Cy. lichenicola grew unstructured and caused turbidity in the medium (Table 2). We examined this fungus and its growth medium microscopically to test for bacterial contamination. No contamination was detectable, only fungal mycelium was present.

\section{$\mathrm{N}_{2} \mathrm{O}$ production}

Every fungal species produced $\mathrm{N}_{2} \mathrm{O}$ in the presence of $\mathrm{NO}_{3}{ }^{-}$and $\mathrm{NO}_{2}{ }^{-}$, except for $C$. funicola, which produced $\mathrm{N}_{2} \mathrm{O}$ solely with $\mathrm{NO}_{2}{ }^{-}$(Table 2). Production rates of $\mathrm{N}_{2} \mathrm{O}$ per biomass were significantly higher with $\mathrm{NO}_{2}^{-}$than with $\mathrm{NO}_{3}{ }^{-}(P<0.001)$ and differed significantly between the fungal structure $(P=0.001)$, but were independent of fungal species $(P=0.124)$. The progress of the reaction in Setup B was always $\leq 0.4 \%$ (Table 2), so that only a small portion of the added electron acceptor $\left(\mathrm{NO}_{3}{ }^{-}, \mathrm{NO}_{2}{ }^{-}\right)$was consumed by denitrification. Setup A reached a reaction progress between 2 and $8 \%$ for $\mathrm{NO}_{2}{ }^{-}$and 0.01 to $0.06 \%$ for $\mathrm{NO}_{3}{ }^{-}$ (Table 2). 


\section{SP of $\mathbf{N}_{2} \mathbf{O}$}

Among all fungi, C. funicola showed the significantly smallest SP of $19.7 \%$. All other fungi produced similar SP $(31.7 \pm 1.4 \%$ o) (Table 2$)$. SP was independent of species $(P=0.716)$, electron acceptors $(P=0.289)$ and structure of fungal species $(P=0.778)$ (ANOVA without C. funicula). The post hoc tests following the ANOVA including $C$. funicula $(P<0.001)$ to test if SP of $\mathrm{N}_{2} \mathrm{O}$ differed between species showed that only SP of $\mathrm{N}_{2} \mathrm{O}$ produced by $C$. funicula differed from all other species, while SP of $\mathrm{N}_{2} \mathrm{O}$ produced by the other species did not differ between them.

\section{$\delta^{18} \mathrm{O}$ and $\delta^{15} \mathrm{~N}_{\text {bulk }}$ of $\mathrm{N}_{2} \mathrm{O}$}

Both $\delta^{18} \mathrm{O}$ and $\delta^{15} \mathrm{~N}_{\text {bulk }}$ values of $\mathrm{N}_{2} \mathrm{O}$ produced were far more variable $\left(\delta^{15} \mathrm{~N}_{\text {bulk }}=-29.5\right.$ to $-51.7 \%$, $\delta^{18} \mathrm{O}=11.8$ to $55.3 \%$ ) than SP (Table 2). Compared to the relatively constant SP values of five Hypocreales fungi, their $\delta^{15} \mathrm{~N}_{\text {bulk }}$ values were highly variable $\left(\delta^{15} \mathrm{~N}_{\text {bulk }}=-39.8 \pm 7.7 \%\right.$ with $\mathrm{NO}_{2}{ }^{-}$and $-36.5 \pm 6.7$ \%o with $\left.\mathrm{NO}_{3}{ }^{-}\right)$. Furthermore, the $\delta^{18} \mathrm{O}$ values varied widely among Hypocreales species with $\mathrm{NO}_{3}{ }^{-}$as electron acceptor $\left(\delta^{18} \mathrm{O}=43.6 \pm 10.2 \%\right.$ \% $)$ in contrast to treatments with $\mathrm{NO}_{2}{ }^{-}\left(\delta^{18} \mathrm{O}=36.5 \pm 2.0 \%\right)$. Only $C$. funicola, the only Sordariales species, produced SP $(19.7 \pm 1.3 \%)$ and $\delta^{18} \mathrm{O}(11.8 \pm 0.3 \%$ o values deviating from the Hypocreales values, while $\delta^{15} \mathrm{~N}_{\text {bulk }}$ values were within the range of the Hypocreales $\left(-39.9 \pm 0.4 \%\right.$ ). The $\Delta \delta^{15} \mathrm{~N}_{\text {bulk }}$ was highly variable (-46 to $-9 \%$ ) and it was independent of fungal species $(P=0.229$ ). It was remarkable that the absolute values of $\Delta \delta^{15} \mathrm{~N}_{\text {bulk }}$ of $\mathrm{N}_{2} \mathrm{O}$ were significantly higher in treatments with $\mathrm{NO}_{2}^{-}$than in treatments with $\mathrm{NO}_{3}{ }^{-}(P<0.001)$ and were significantly dependent on the structure of fungal species $(P<0.001)$.Our results show the following relation between the visual structure of fungi and $\Delta \delta^{15} \mathrm{~N}_{\text {bulk }}$ (see Table 2): For both electron acceptors, the largest $\Delta \delta^{15} \mathrm{~N}_{\text {bulk }}$ was observed from the globose (g) forming fungi (g) (-17.5 to $-29.3 \%$ with $\mathrm{NO}_{2}{ }^{-}$and -42.9 to $-45.5 \%$ with $\mathrm{NO}_{3}$ ), and the lowest $\Delta \delta^{15} \mathrm{~N}_{\text {bulk }}$ from turbid (t) grown fungus (Cy. lichenicola, -8.8 \%o with $\mathrm{NO}_{2}{ }^{-}$and $-30.8 \%$ with $\mathrm{NO}_{3}{ }^{-}$). The $\Delta \delta^{15} \mathrm{~N}_{\text {bulk }}$ values for the mixed growth type with globose formation in turbid medium (gt) were between those of the other growth forms (-13.8 to -14.0 \%o with $\mathrm{NO}_{2}{ }^{-}$and -31.6 to -38.0 \%o with $\mathrm{NO}_{3}{ }^{-}$). Furthermore the absolute value of $\Delta \delta^{15} \mathrm{~N}_{\text {bulk }}$ decreased significantly with increasing $\mathrm{N}_{2} \mathrm{O}$ production $(P<0.001$; Figure 1$)$. 
Table 2: Fungal growth, $\mathrm{N}_{2} \mathrm{O}$ production and isotopic composition of $\mathrm{N}_{2} \mathrm{O}\left({ }^{15} \mathrm{~N}\right.$ site preference, $\left.\delta^{18} \mathrm{O}, \delta^{15} \mathrm{~N}_{\text {bulk }}\right)$ in incubation studies with six different fungal species and with addition of nitrate and nitrite as electron acceptor for denitrification (standard deviation in brackets, $\mathrm{n}=3$ ).

\begin{tabular}{|c|c|c|c|c|c|c|c|c|c|}
\hline Species & $\begin{array}{l}\text { Electron } \\
\text { acceptor }\end{array}$ & $\begin{array}{l}\text { fungal } \\
\text { growth }^{\mathrm{a}}\end{array}$ & $\begin{array}{c}\text { Biomass }^{\mathrm{b}} \\
{[\mathrm{g}]}\end{array}$ & $\begin{array}{c}\mathrm{N}_{2} \mathrm{O} \text { production } \\
\text { [nmol } \mathrm{N}_{2} \mathrm{O} \\
\left.\mathrm{g}^{-1} \mathrm{~h}^{-1}\right]\end{array}$ & $\begin{array}{c}{ }^{15} \mathrm{~N} \text { site } \\
\text { preference } \\
{[\%]}\end{array}$ & $\begin{array}{l}\delta^{18} \mathrm{O} \\
{[\% \circ]}\end{array}$ & $\begin{array}{c}\delta^{15} \mathrm{~N}_{\text {bulk }} \\
{[\% \text { o] }}\end{array}$ & $\begin{array}{c}\text { Reaction } \\
\text { progress }^{\mathrm{d}} \\
{[\%]}\end{array}$ & $\Delta \delta^{15} \mathrm{~N}_{\text {bulk }}{ }^{\mathrm{e}}$ \\
\hline Cy. lichnenicola & $\mathrm{NO}_{2}^{-}$ & $\mathrm{t}$ & $0.22(0.16)$ & 8800 (2498) & $30.19(0.89)$ & $37.62(1.68)$ & $-31.20(4.78)$ & $7.69(2.16)$ & $-8.8(4.8)$ \\
\hline F. decemcellulare & $\mathrm{NO}_{2}^{-}$ & g & $0.11(0.09)$ & 7709 (943) & $31.76(0.82)$ & $36.14(0.80)$ & $-51.70(2.58)$ & $2.08(0.70)$ & $-29.3(2.6$ \\
\hline F. solani fsp. pisi & $\mathrm{NO}_{2}^{-}$ & gt & $0.06(<0.01)$ & 13865 (118) & $32.00(0.42)$ & $38.40(0.32)$ & $-36.20(0.05)$ & $8.23(0.06)$ & $-13.3(0.1)$ \\
\hline F. oxysporum & $\mathrm{NO}_{2}^{-}$ & gt & $0.04(<0.01)$ & 2441 (1255) & $31.15(2.36)$ & $33.35(0.59)$ & $-36.36(3.00)$ & $0.328(0.169)$ & $-14.0(3.0$ \\
\hline T. hamatum & $\mathrm{NO}_{2}^{-}$ & g & $0.02(<0.01)$ & 1561 (128) & $31.01(0.27)$ & $36.90(0.70)$ & $-43.47(0.09)$ & $0.420(0.034)$ & $-21.7(0.1)$ \\
\hline C. funicola & $\mathrm{NO}_{2}^{-}$ & g & $0.01(<0.01)$ & $52(10)$ & $19.66(1.27)$ & $11.83(0.28)$ & $-39.90(0.40)$ & $0.005(0.001)$ & $-17.5(0.4$ \\
\hline Cy. lichnenicola & $\mathrm{NO}_{3}^{-}$ & $\mathrm{t}$ & $0.11(0.02)$ & 140 (96) & 32.35 (1.64) & 45.67 (1.17) & $-29.52(1.83)$ & $0.06(0.04)$ & $-30.9(1.8$ \\
\hline F. decemcellulare & $\mathrm{NO}_{3}{ }^{-}$ & g & $0.11(0.03)$ & $47(26)$ & $31.93(2.77)$ & $38.20(8.65)$ & $-44.22(3.82)$ & $0.01(0.01)$ & $-45.6(3.8$ \\
\hline F. solani fsp. pisi & $\mathrm{NO}_{3}^{-}$ & gt & $0.08(<0.01)$ & $155(163)$ & $32.00(1.72)$ & $43.46(6.16)$ & $-30.27(4.98)$ & $0.04(0.04)$ & $-31.6(5.0$ \\
\hline F. oxysporum & $\mathrm{NO}_{3}^{-}$ & gt & $0.04(0.01)$ & $162(100)$ & 32.59 (2.19) & $55.32(13.33)$ & $-36.68(1.54)$ & $0.001(<0.001)$ & $-38.0(1.5$ \\
\hline T. hamatum & $\mathrm{NO}_{3}^{-}$ & g & $0.06(0.02)$ & $129(185)$ & $31.18(0.14)$ & $35.23(1.40)$ & $-41.56(2.93)$ & $0.002(0.003)$ & $-42.9(2.9$ \\
\hline C. funicola & $\mathrm{NO}_{3}^{-}$ & g & $0.01(<0.01)$ & n.d. & n.d. & n.d. & n.d. & n.d. & n.d. \\
\hline
\end{tabular}

an.d. = not detectable; $C$. funicola did not produce $\mathrm{N}_{2} \mathrm{O}$ with $\mathrm{NO}_{3}{ }^{-}$as electron acceptor.

${ }^{\mathrm{b}}$ The appearance of fungal cultures in the medium was turbid (t), globose (g) or a mixture of globose and turbid (gt).

${ }^{\mathrm{c}}$ The average biomass ( $\mathrm{g} \mathrm{dw}$ ) of each fungal species after the experiment was used to relate the $\mathrm{N}_{2} \mathrm{O}$ production to fungal biomass.

${ }^{\mathrm{d}}$ Reaction progress is calculated by the relative quotient of $\mathrm{N}_{2} \mathrm{O}-\mathrm{N}$ production and the precursor $\mathrm{N}$-amount added (see Eq. 3).

${ }^{\mathrm{e}} \Delta \delta^{15} \mathrm{~N}_{\text {bulk }}$ describes the difference of the isotopic $\mathrm{N}$ signature of the product $\left(\mathrm{N}_{2} \mathrm{O}\right)$ and the isotopic $\mathrm{N}$ signature of the substrate ( $\mathrm{NO}_{2}^{-}$or $\mathrm{NO}_{3}{ }^{-}$), respectively (see Eq. 4). 


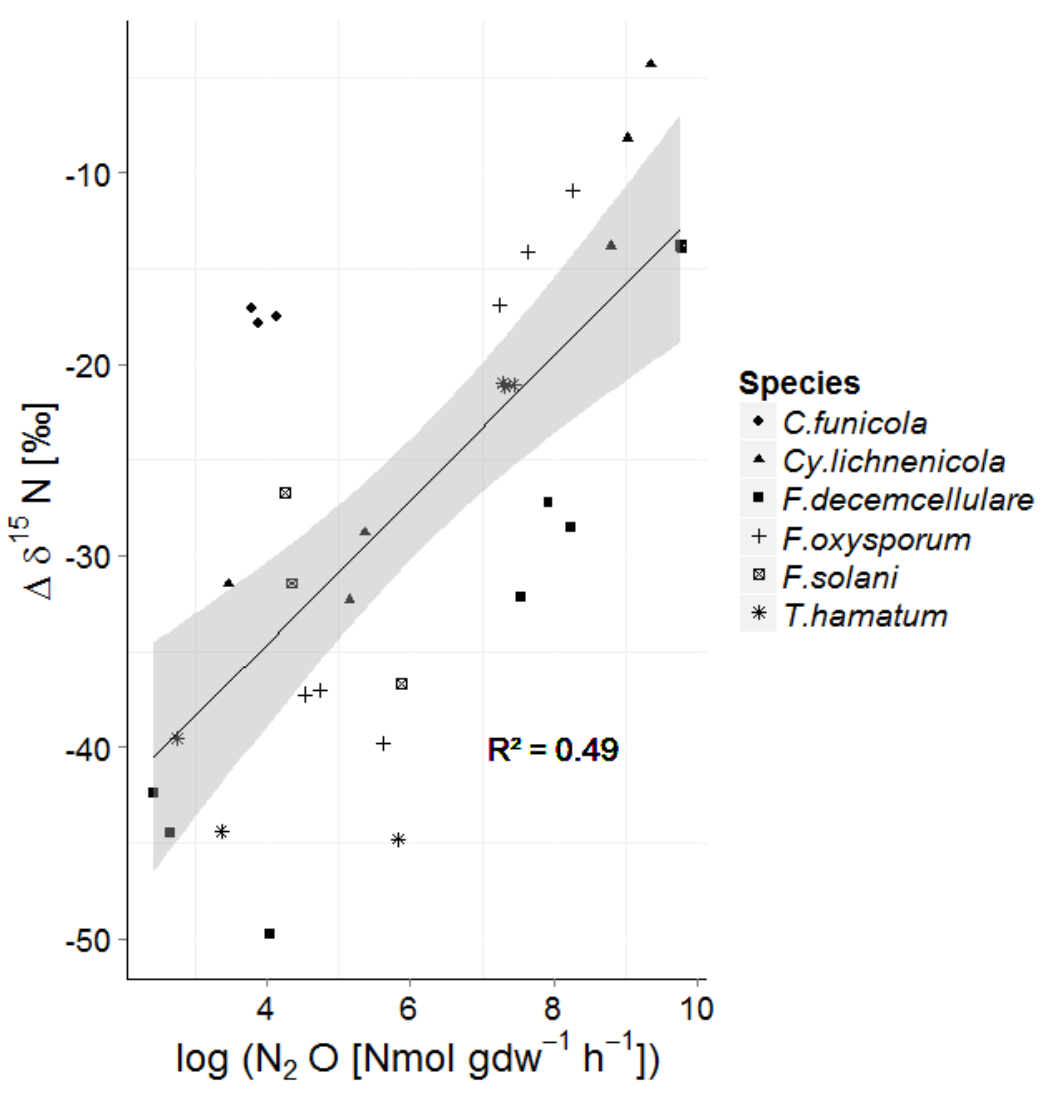

Figure 1: $\Delta \delta^{15} \mathrm{~N}\left[\%\right.$ o] depending on the $\log _{10}$-transformed $\mathrm{N}_{2} \mathrm{O}$ production rate after seven days of incubation (with nitrate and nitrite) by six different fungal species with linear regression and $95 \%$ confidence interval (Regression: $y=-49.7+3.8 x$ ).

\section{$\underline{\text { Discussion }}$}

\section{$\mathrm{N}_{2} \mathrm{O}$ production and $\mathrm{SP}$ of $\mathrm{N}_{2} \mathrm{O}$}

With respect to the potential use of SP of $\mathrm{N}_{2} \mathrm{O}$ to identify fungal denitrification, the questions are (1.) whether SP of produced $\mathrm{N}_{2} \mathrm{O}$ depends only on the enzyme type (Schmidt et al., 2004), (2.) if there is an additional species effect for a certain enzyme type, and (3.) if $\mathrm{N}_{2} \mathrm{O}$ production dynamics are relevant:

1. We analyzed the $\mathrm{SP}$ of $\mathrm{N}_{2} \mathrm{O}$ produced by four additional fungal species as compared to the two fungal species examined by Sutka et al. (2008). Variation of SP of $\mathrm{N}_{2} \mathrm{O}$ produced by F. oxysporum and Cy. lichenicola with $\mathrm{NO}_{2}^{-}$of our experiment was within the individual measurements by Sutka et al. (2008) (cf. Table 2 and Table 1 in Sutka et al. (2008)), although the mean SP of $\mathrm{N}_{2} \mathrm{O}$ of both species of the present study was about 6 \%o lower compared to the declared mean SP values of Sutka et al. (2008). All six fungal species studied here produced $\mathrm{N}_{2} \mathrm{O}$ with a substantially higher SP (19.7 to $32.6 \%$ ) than reported for bacteria (-11 to $0 \%$ ) (Frame and Casciotti, 2010; Sutka et al., 2006). However, SP of C. funicola 
compared to the other five fungi was in between the fungal SP (33 to 37 \%o potentially with P450nor) and the bacterial SP (0 to -11 \%o with cnor) (Frame and Casciotti, 2010; Sutka et al., 2008; Sutka et al., 2006). As SP values of $\mathrm{N}_{2} \mathrm{O}$ are independent of the substrate (Sutka et al., 2006; Toyoda et al., 2002), enzyme activity might be a control of SP produced. The sequential binding of NO could be dependent on the enzyme activity and thus could result in different fractionation during the addition of the first or the second NO. Another controlling factor resulting in lower $\mathrm{SP}$ of $\mathrm{N}_{2} \mathrm{O}$ by $C$. funicola compared to the other five fungal species might point to the occurrence of a different Nor than the typical P450nor for fungi. However, so far there is no information about fungal Nors other than P450nor, which was well examined for $F$. oxysporum and $C$. tonkinense and to our knowledge only for species of the order Hypocreales (Shoun et al., 2012; Shoun and Tanimoto, 1991). There is no information available on the Nor type of $C$. funicola.

2. If it could be confirmed that the Nor type of $C$. funicula differs from specific P450nor and that all Hypocreales have the same enzyme, we could conclude that the similarities of SP among Hypocreales indicate that there is no significant species effect and SP might be controlled by the enzyme type. But this conclusion would be invalid if $C$. funicula turned out to have P450nor. Further studies are needed to examine the enzymatic structure for fungal species under examination.

3. Neither the $\mathrm{N}_{2} \mathrm{O}$ production rate nor the availability of two different electron acceptors affected the SP of the $\mathrm{N}_{2} \mathrm{O}$ produced, which agrees with results of previous studies with bacteria (Toyoda et al., 2002). We did not directly test the impact of $\mathrm{NO}_{3}{ }^{-}$or $\mathrm{NO}_{2}{ }^{-}$ concentration on SP. Because reaction progress was always relatively small, the $\delta^{15} \mathrm{~N}_{\text {bulk }}$ of the electron acceptors should not have changed much during the incubation period. However, we cannot rule out local depletion of $\mathrm{NO}_{3}{ }^{-}$or $\mathrm{NO}_{2}{ }^{-}$due to the structure of fungal species (e.g., in the globose type cultures; see also next section for detailed discussion). But if such differences in local depletion existed among Hypocreales species, apparently they did not significantly affect $\mathrm{SP}$ values of $\mathrm{N}_{2} \mathrm{O}$.

What is still missing is the knowledge about the archaeal contribution to denitrification (Santoro et al., 2011; Thomson et al., 2012). Information so far showed that the archaeal denitrification pathway is similar to bacterial denitrification (Hayatsu et al., 2008). To the best of our knowledge there is no information available about the isotopic fingerprint of $\mathrm{N}_{2} \mathrm{O}$ originating from archaeal denitrification. 


\section{$\mathrm{N}$ fractionation effects derived from $\delta^{15} \mathrm{~N}_{\text {bulk }}$ of $\mathrm{N}_{2} \mathrm{O}$}

The $\Delta \delta^{15} \mathrm{~N}$ values of $\mathrm{N}_{2} \mathrm{O}$ (difference of $\delta_{p}$ and $\delta_{s}$, Eq. 4) we determined for fungal $\mathrm{N}_{2} \mathrm{O}$ production from $\mathrm{NO}_{2}{ }^{-}\left(-8.8\right.$ to $-29.3 \%$ ) as well as from $\mathrm{NO}_{3}{ }^{-}(-30.8$ to $-45.5 \%$ o) were in the range of data from two fungal strains reported in a previous study by Sutka et al. giving -6.6 to -74.7 \%o with $\mathrm{NO}_{2}^{-}$as electron acceptor (Sutka et al., 2008). Snider et al. (2009) summarized previous literature data of ${ }^{15} \mathrm{~N}$ fractionation effects for $\mathrm{N}_{2} \mathrm{O}$ produced during bacterial denitrification in a similar range between -10 and -39\%. Isotope fractionation effects of $\mathrm{N}$ observed in pure culture experiments seem to overlap for fungal and bacterial denitrification as well as for nitrification (Ostrom and Ostrom, 2011). This is clearly confirmed by our results from fungal pure cultures, which cover the wide range of $\mathrm{N}$ fractionation factors known from bacterial denitrification and nitrification (Barford et al., 1999; Ostrom and Ostrom, 2011; Perez et al., 2006; Sutka et al., 2008; Yoshida, 1988). Along with this, soil incubation under denitrifying conditions resulted in similar $\mathrm{N}$ fractionation factors from -10 to -54 \%o (summarized by Snider et al., 2009; Well and Flessa, 2009). Hence, $\delta^{15} \mathrm{~N}_{\text {bulk }}$ values of the produced $\mathrm{N}_{2} \mathrm{O}\left(\delta^{15} \mathrm{~N}_{\text {bulk }}-\mathrm{N}_{2} \mathrm{O}\right)$ alone cannot be used to differentiate between microbial sources or pathways of $\mathrm{N}_{2} \mathrm{O}$ production (Ostrom and Ostrom, 2011), but a closer look at $\mathrm{N}$ isotope effects controlling $\delta^{15} \mathrm{~N}_{\text {bulk }}-\mathrm{N}_{2} \mathrm{O}$ might improve our understanding of the predominant process steps influencing the isotopic fractionation during denitrification (Ostrom and Ostrom, 2011; Sutka et al., 2008).

Net isotope effects $(\eta)$, the sum of isotopic fractionations associated with the individual reduction steps of denitrification, can be described by the equation of Farquhar et al. (1982), which was adapted to $\mathrm{N}_{2} \mathrm{O}$ production during fungal denitrification by Ostrom and Ostrom (see Eq. 12 in Ostrom and Ostrom (2011)). To interpret $\delta^{15} \mathrm{~N}_{\text {bulk }}-\mathrm{N}_{2} \mathrm{O}$ we assume that $\eta_{15 \mathrm{~N}}$ is represented by the $\Delta \delta^{15} \mathrm{~N}$ values (Eq. 4, Figure 1, Table 2). In line with Sutka et al. (2008), our results (e.g., for $F$. oxysporum) showed that larger reaction rates (= large $\mathrm{N}_{2} \mathrm{O}$ production) were associated with smaller $\Delta \delta^{15} \mathrm{~N}$ values compared to samples with smaller $\mathrm{N}_{2} \mathrm{O}$ production (Figure 1). At high reaction rates, the enzyme activity and diffusion out of the cell is relatively large compared to diffusion into the cell (Ostrom and Ostrom, 2011). In this case $\Delta \delta^{15} \mathrm{~N}$ is mainly controlled by the fractionation of diffusion, whereas higher fractionation factors and lower $\mathrm{N}_{2} \mathrm{O}$ productions indicate a dependence on the enzymatic fractionation (Ostrom and Ostrom, 2011; Well and Flessa, 2008).

Also, our results show a significant relation between the visual structure of fungi and $\Delta \delta^{15} \mathrm{~N}$ for both electron acceptors (see Table 2). Here the most negative and lowest negative $\Delta \delta^{15} \mathrm{~N}$ was for the globose (g) forming and turbid (t) grown fungi, respectively, while 
$\Delta \delta^{15} \mathrm{~N}$ was in between for the mixed growth type (gt). We therefore suspect that the different growth types might have caused differences in the apparent isotope effects, which are reflected by the bulk isotopic values observed in our incubation vessels. Apparent isotope effects can be substantially lower compared to actual net isotope effects $(\eta)$ in active microsites or cells due to spatial heterogeneity of processes including dispersion of substrates, reduction processes in isolated micro-niches and heterogeneity of reaction rates (Well et al., 2012). But we have no obvious explanation why apparent isotope effects should be larger in globose structures since complete consumption or high enrichment in isolated micro niches would lead to the opposite of our observations and isotope effect of diffusion into the globose grown fungi should be negligible (Granger et al., 2008; Mariotti et al., 1988). Hence, the reason for the observed growth pattern effect needs further clarification to get a better understanding about fungal fractionation during $\mathrm{N}_{2} \mathrm{O}$ production, although the observed differences in growth pattern will be irrelevant under natural conditions in soil.

\section{$\delta^{18} \mathrm{O}$ of $\mathrm{N}_{2} \mathrm{O}$}

The $\delta^{18} \mathrm{O}-\mathrm{N}_{2} \mathrm{O}$ was far more variable $\left(\delta^{18} \mathrm{O}=11.83\right.$ to $55.3 \%$ ) compared to SP of $\mathrm{N}_{2} \mathrm{O}$ (Table 2) and was affected by isotopic fractionation during subsequent reduction steps (similarly as described above for $\mathrm{N}$ fractionation) as well as by $\mathrm{O}$ exchange between $\mathrm{H}_{2} \mathrm{O}$ and denitrification intermediates (Rohe et al., 2014). This makes interpretation of the $\delta^{18} \mathrm{O}-\mathrm{N}_{2} \mathrm{O}$ more complicated than that of $\delta^{15} \mathrm{~N}_{\text {bulk }}-\mathrm{N}_{2} \mathrm{O}$. Therefore we estimated the $\mathrm{O}$ isotopic fractionation and $\mathrm{O}$ exchange during several steps of denitrification using a conceptual model (Rohe et al., 2014) adapted from previous concepts for bacterial denitrification after Casciotti et al. (2007), implementing controls of O exchange proposed by Aerssens et al. (1986) and using fractionation models developed by Snider et al. (Figure 2) (Aerssens et al., 1986; Snider et al., 2010; Snider et al., 2012, 2013). The fractionation model is based on the assumption that every reduction step by $\mathrm{NO}_{3}{ }^{-}$reductase (Nar), $\mathrm{NO}_{2}{ }^{-}$reductase (Nir) and Nor during denitrification is characterized by specific branching effects, i.e., kinetic isotopic fractionation during enzymatic reactions $\left(\varepsilon_{1}\right)$ and equilibrium effects due to $\mathrm{O}$ exchange between $\mathrm{H}_{2} \mathrm{O}$ and denitrification intermediates $\left(\varepsilon_{2}\right)$ (Casciotti et al., 2007). The fraction of $\mathrm{O}$ exchange during each reduction step is defined as $f_{N a r}, f_{N i r}$ and $f_{N o r}$, respectively. Based on this we can calculate the $\delta^{18} \mathrm{O}\left(\delta^{18} \mathrm{O}_{f}\right)$ of the particular intermediate or final product $\left(\mathrm{NO}_{2}{ }^{-}\right.$, NO or $\left.\mathrm{N}_{2} \mathrm{O}\right)$ :

$\delta^{18} \mathrm{O}_{\mathrm{f}}=\left(1-\mathrm{f}_{\mathrm{ex}}\right)\left(\delta^{18} \mathrm{O}_{\mathrm{i}}+\varepsilon_{1}\right)+\mathrm{f}_{\mathrm{ex}}\left(\varepsilon_{2}+\delta^{18} \mathrm{O}_{\text {water }}\right)$ 
with $f_{e x}$ describing the fraction of $\mathrm{O}$ exchange between denitrification intermediates and $\mathrm{H}_{2} \mathrm{O}$ during the particular reduction step $\left(f_{\text {Nar }}, f_{\text {Nir }}\right.$ or $\left.f_{\text {Nor }}\right), \delta^{18} O_{i}$ representing $\delta^{18} \mathrm{O}$ of the initial precursors $\left(\mathrm{NO}_{3}{ }^{-}, \mathrm{NO}_{2}{ }^{-}\right.$and $\left.\mathrm{NO}\right)$, and $\delta^{18} \mathrm{O}_{\text {water }}$ representing $\delta^{18} \mathrm{O}$ value of the $\mathrm{H}_{2} \mathrm{O}$.

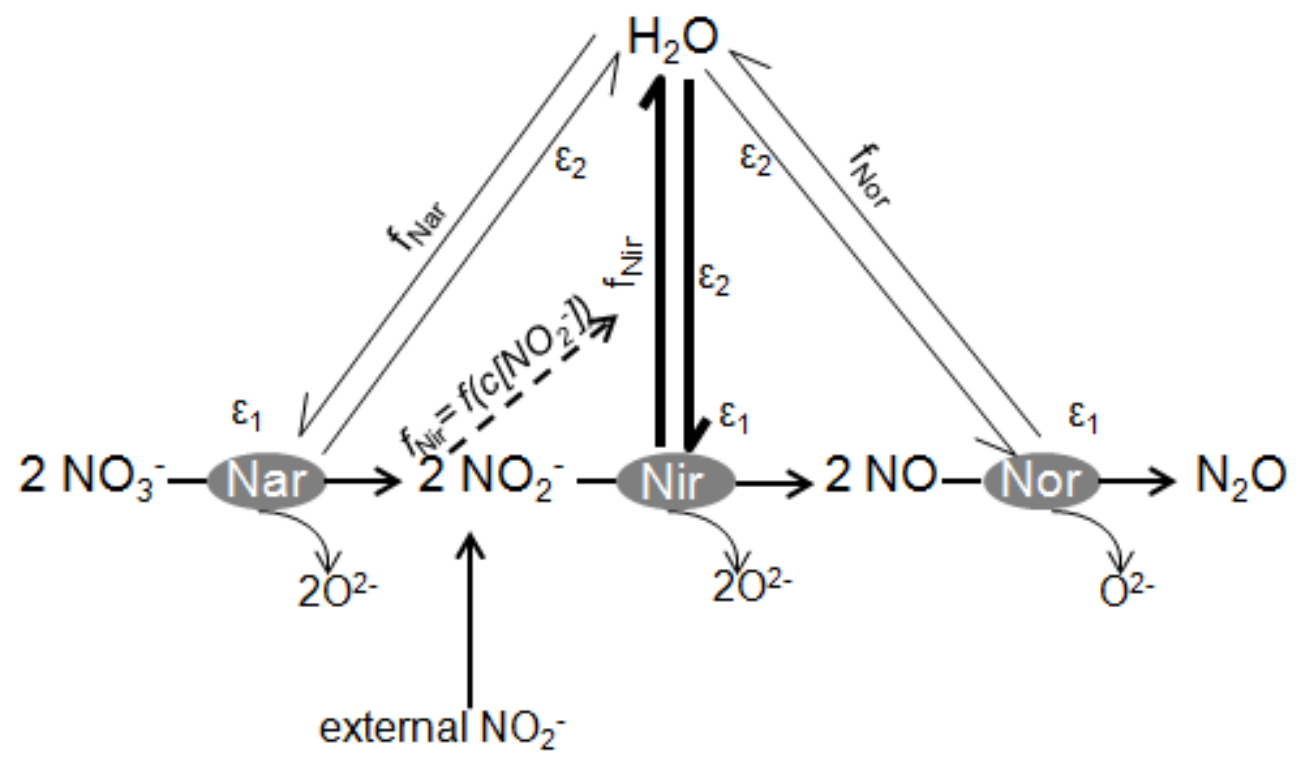

Figure 2: Conceptual model of fungal denitrification adopted from a model by Snider et al. (2013), Casciotti et al. (2007) and Aerssens et al. (1986), after Rohe et al. (2014), modified. The bold arrow shows the enzymatic step of the presumably main oxygen exchange, whereas thin arrows show the step with presumably less oxygen exchange.

To assess $f_{N a r}, f_{N i r}$ and $f_{\text {Nor }}$ with this model, the values for the extent of the total $\mathrm{O}$ exchange had to be known and were taken from Rohe et al. (2014). In that study, the $\mathrm{O}$ exchange between $\mathrm{H}_{2} \mathrm{O}$ and denitrification intermediates was determined with ${ }^{18} \mathrm{O}$-labeled $\mathrm{H}_{2} \mathrm{O}$ for all six fungal species also examined in this study. Total $\mathrm{O}$ exchange between denitrification intermediates and water varied between 0.41 and full exchange with a standard deviation between 0.01 and 0.06 , whereas with nitrate variation was between 0.11 and full exchange with a standard deviation between 0.02 and 0.34 (Rohe et al., 2014). We assume the same extent of $\mathrm{O}$ exchange for fungi in both this and the previous experiment. However, the experiment using ${ }^{18} \mathrm{O}$-labeled $\mathrm{H}_{2} \mathrm{O}$ provides only information about the total extent of $\mathrm{O}$ exchange, i.e., how many ${ }^{18} \mathrm{O}$ atoms were exchanged between enriched medium $\mathrm{H}_{2} \mathrm{O}$ and the final product during the whole reaction sequence. Since this $\mathrm{O}$ exchange may take place due to the three following enzymatic reaction steps: Nar, Nir and Nor (Figure. 2), the total O exchange $\left(t_{e x}\right)$ can be defined as follows: 
$t_{\text {ex }}=f_{\text {Nor }}+f_{\text {Nir }}\left(1-f_{\text {Nor }}\right)+f_{\text {Nar }}\left(1-f_{\text {Nir }}\right)\left(1-f_{\text {Nor }}\right)$

The time point when the $\mathrm{O}$ exchange occurs is crucial for the $\mathrm{O}$ isotopic signature of the final $\mathrm{N}_{2} \mathrm{O}$ : If the majority of this $\mathrm{O}$ exchange appears in the initial reduction steps (i.e., Nar or Nir reduction steps) the branching effect occurring later will mainly determine the final $\delta^{18} \mathrm{O}-\mathrm{N}_{2} \mathrm{O}$, resulting in higher values due to isotopic fractionation. Conversely, if $\mathrm{O}$ exchange occurs during the final reduction step by Nor, branching effects during preceding steps are partly or fully erased and the final $\delta^{18} \mathrm{O}-\mathrm{N}_{2} \mathrm{O}$ signature will be governed by $\mathrm{O}$ exchange effects including the equilibrium effect and the $\delta^{18} \mathrm{O}$ of $\mathrm{H}_{2} \mathrm{O}$. Therefore, we deciphered the mechanism of $\mathrm{O}$ exchange with $\mathrm{H}_{2} \mathrm{O}$ by applying model calculations based on Eq. 6 (Table 3 for $\mathrm{NO}_{2}{ }^{-}$and Table 4 for $\mathrm{NO}_{3}{ }^{-}$) which were based on the measured $\delta^{18} \mathrm{O}-\mathrm{N}_{2} \mathrm{O}$ values. The initial $\delta^{18} \mathrm{O}$ values of O precursors were: $-22.7 \%$ for $\mathrm{NO}_{2}{ }^{-} ; 22.0 \%$ for $\mathrm{NO}_{3}{ }^{-} ;-9.9 \%$ for $\mathrm{H}_{2} \mathrm{O}$ in the medium of $C$. lychenicola, F. solani fsp. pisi, F. decemcellulare , and -8.9 \%o for that of C. funicola, F. oxysporum and T. hamatum. We assumed the values for isotope effects according to Casciotti et al. (2007): the branching effect $\left(\varepsilon_{1}\right)$ of Nir and Nor each with $30 \%$ and the equilibrium effect $\left(\varepsilon_{2}\right)$ of Nir and Nor with $14 \%$. To assess $\mathrm{f}_{\mathrm{Nir}}$ and $\mathrm{f}_{\mathrm{Nor}}$ when $\mathrm{NO}_{2}{ }^{-}$ was added as electron acceptor, we calculated three scenarios (Table 3): I. we supposed $\mathrm{O}$ exchange only takes place at Nor $\left(f_{\text {Nir }}=0\right)$; or II. only at Nir $\left(f_{\text {Nor }}=0\right)$, or III. we fitted measured and modeled $\delta^{18} \mathrm{O}-\mathrm{N}_{2} \mathrm{O}$ values by adjusting $\mathrm{O}$ exchange during Nir and Nor steps. 
Table 3: Results of modeling oxygen exchange with water during nitrite reduction to $\mathrm{N}_{2} \mathrm{O}$ using Eq. 6. Three scenarios were calculated to assess the fractions of oxygen exchange at $\operatorname{Nir}\left(\mathrm{f}_{\mathrm{Nir}}\right)$ and oxygen exchange at Nor $\left(\mathrm{f}_{\mathrm{Nor}}\right)$ : I. we supposed oxygen exchange only takes place at Nor ( $\left.\mathrm{f}_{\text {Nir }}=0\right)$, or II. only at $\mathrm{Nir}\left(\mathrm{f}_{\mathrm{Nor}}=0\right)$ or III. measured and modeled $\delta^{18} \mathrm{O}-\mathrm{N}_{2} \mathrm{O}$ values were fitted by adjusting $\mathrm{f}_{\mathrm{Nir}}$ and $\mathrm{f}_{\mathrm{Nor}}$. Calculated $\delta^{18} \mathrm{O}$ values of $\mathrm{NO}$ and $\mathrm{N}_{2} \mathrm{O}$ are shown and the goodness of fit is given as difference of measured and calculated $\delta^{18} \mathrm{O}-\mathrm{N}_{2} \mathrm{O}$ (Difference meas.- calc. $\delta^{18} \mathrm{O}-\mathrm{N}_{2} \mathrm{O}$ ). Calculations are based on measured $\delta^{18} \mathrm{O}$ values of $\mathrm{NO}$ and $\mathrm{N}_{2} \mathrm{O}$ precursors (22.7\%o for $\mathrm{NO}_{2}{ }^{-} ;-9.9 \%$ for medium $\mathrm{H}_{2} \mathrm{O}$ of C. lychenicola, F. solani fsp. pisi, F. decemcellulare, and -8.9 \%o for medium $\mathrm{H}_{2} \mathrm{O}$ of $C$. funicola, F. oxysporum and T. hamatum) and on isotope effects according to Casciotti et al. (2007) (branching effect $\varepsilon_{1}$ of Nir and Nor each with $30 \%$ and equilibrium effect $\varepsilon_{2}$ of Nir and Nor with $14 \%$ o). Moreover, $\mathrm{f}_{\mathrm{Nir}}$ and $\mathrm{f}_{\text {Nor }}$ assumed in the model scenarios as shown were set to fulfill Eq. 7 using measured values of total oxygen exchange (mean values with standards in brackets) (Rohe et al., 2014).

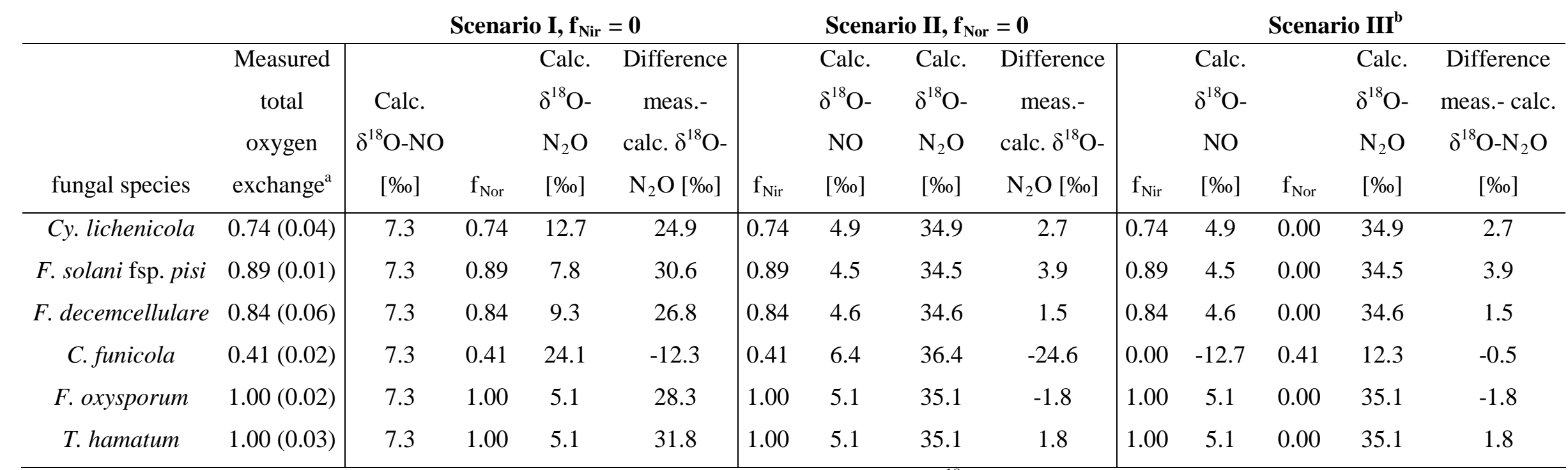

${ }^{\mathrm{a}}$ Data of total $\mathrm{O}$ exchange during denitrification $\left(\mathrm{NO}_{2}{ }^{-}\right.$to $\mathrm{N}_{2} \mathrm{O}$ reduction) were taken from an ${ }^{18} \mathrm{O}$ tracer experiment by Rohe et al. (2014), where the same fungal species were used for incubation studies.

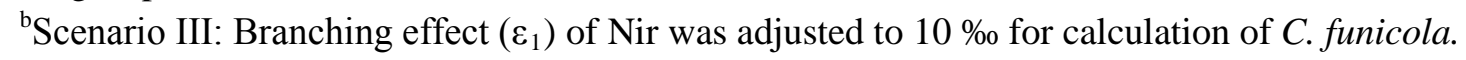


Our results for treatments with $\mathrm{NO}_{2}{ }^{-}$showed that $\delta^{18} \mathrm{O}-\mathrm{N}_{2} \mathrm{O}$ cannot be explained by branching effects during enzymatic steps of $\mathrm{N}_{2} \mathrm{O}$ production alone and further confirmed the impact of O exchange. The results of our three scenarios (Table 3) suggest that $\mathrm{O}$ exchange occurred mostly at Nir. In Scenario I (without $\mathrm{O}$ exchange during $\mathrm{NO}_{2}{ }^{-}$reduction) the calculated ${ }^{18} \mathrm{O}$ values differed largely from measured values, showing that $\delta^{18} \mathrm{O}-\mathrm{N}_{2} \mathrm{O}$ cannot be dominated by $\mathrm{O}$ exchange during NO reduction. In contrast to this, in Scenario II, with the assumption that the $\mathrm{O}$ exchange only takes place during $\mathrm{NO}_{2}{ }^{-}$reduction, the difference between calculated and measured $\delta^{18} \mathrm{O}-\mathrm{N}_{2} \mathrm{O}$ was much smaller. In Scenario III (allowing $\mathrm{O}$ exchange during $\mathrm{NO}_{2}{ }^{-}$and $\mathrm{NO}$ reduction) all five fungi of Hypocreales gave the best fit with $\mathrm{O}$ exchange only at Nir. The fungus $C$. funicola (only Sordariales) yielded a better fit with Scenario I than Scenario II, indicating some O exchange at the Nor step. However, to obtain a good fit with Scenario III, it must be assumed that the branching effect of Nir is smaller $\left(\varepsilon_{1}=\right.$ $10 \%$ ) than assumed for the Hypocreales species (30 \%o). Thus, the isotopic fractionation of the biological order Sordariales needs to be verified by future studies. So far, the existence of P450nor in the fungal denitrifying systems has to our knowledge only been studied and detected in species of Hypocreales (Shoun et al., 1992). In further studies, the P450nor occurrence in fungal denitrifying systems from various orders, including the Sordariales, should be analyzed.

The fractionation mechanism for $\mathrm{NO}_{3}{ }^{-}$treatments is even more complex because we deal with a possible additional $\mathrm{O}$ exchange at Nar (Figure 2). For model simplification, we assumed no branching effect during the nitrate-to-nitrite reduction step, since this branching isotope effect due to the intra-molecular ${ }^{18} \mathrm{O} /{ }^{16} \mathrm{O}$ fractionation (positive $\varepsilon$ ) is compensated by the intermolecular isotope effect resulting in preferential reduction of ${ }^{18} \mathrm{O}$-depleted $\mathrm{NO}_{3}{ }^{-}$ (negative $\varepsilon$ ) (Casciotti and McIlvin, 2007; Snider et al., 2013). Similarly as for $\mathrm{NO}_{2}{ }^{-}$ treatments, we analyzed three scenarios assuming that $\mathrm{O}$ exchange at Nor $=0$ as shown by assessment of data from the $\mathrm{NO}_{2}^{-}$treatments in Hypocreales species: I. we supposed $\mathrm{O}$ exchange only takes place at $\operatorname{Nir}\left(\mathrm{f}_{\mathrm{Nar}}=0\right.$ and $\left.\mathrm{f}_{\mathrm{Nor}}=0\right)$; II. O exchange occurs only at Nar $\left(\mathrm{f}_{\mathrm{Nir}}=0\right.$ and $\left.\mathrm{f}_{\mathrm{Nor}}=0\right)$, and III. we fitted measured and modeled $\delta^{18} \mathrm{O}-\mathrm{N}_{2} \mathrm{O}$ values by adjusting $\mathrm{O}$ exchange during Nar and Nir steps $\left(\mathrm{f}_{\mathrm{Nor}}=0\right)$ and also by adjusting the magnitude of the branching effect. Our results for treatments with $\mathrm{NO}_{3}{ }^{-}$showed that the isotopic signature of ${ }^{18} \mathrm{O}$ in $\mathrm{N}_{2} \mathrm{O}$ is as well as for $\mathrm{NO}_{2}{ }^{-}$treatments affected by $\mathrm{O}$ exchange. Results of our three scenarios (Table 4) indicate that $\mathrm{O}$ exchange might mostly occur by Nir but possibly with different branching effects $\left(\varepsilon_{1}\right)$ than postulated by Casciotti et al. (2007). In Scenario I (without $\mathrm{O}$ exchange during $\mathrm{NO}_{3}{ }^{-}$reduction or $\mathrm{NO}$ reduction) the calculated $\delta^{18} \mathrm{O}$ values are 
mostly higher than the measured values for all fungi with the exception of $F$. solani fsp. pisi. In Scenario II, with the assumption that the $\mathrm{O}$ exchange only takes place at Nar, the difference between calculated and measured $\delta^{18} \mathrm{O}$ values is even higher than in Scenario I. From these first two scenarios it is particularly noticeable that $F$. solani fsp. pisi shows a very distinct $\mathrm{O}$ fractionation mechanism than the other fungi. Moreover, during the previous experiment determining total $\mathrm{O}$ exchange (Rohe et al., 2014) this was also the only fungus showing higher $\mathrm{O}$ exchange with $\mathrm{NO}_{3}{ }^{-}$than with $\mathrm{NO}_{2}{ }^{-}$, which suggests that the additional $\mathrm{O}$ exchange must have occurred at Nar. Hence, in Scenario III for this fungus we accepted the total O exchange at both enzymatic steps Nar and Nir (according to the Eq. 7) and adjusted the magnitude of the $f_{\text {Nir }}$ to get the best agreement between measured and calculated values. For the other four fungi of Hypocreales in Scenario III, Nir was the enzyme assumed to be solely responsible for $\mathrm{O}$ exchange, since the calculated values in Scenario I were closer to the actually measured values. This is in accordance with the previous experiment determining total O exchange,(Rohe et al., 2014) where for those fungi lower O exchange was found for $\mathrm{NO}_{3}{ }^{-}$treatments suggesting no additional $\mathrm{O}$ exchange at Nar. However, the values calculated in Scenario I are still very different from the actually measured values. This discrepancy can only be reduced by lowering the assumed isotopic fractionation associated with the branching effect. This was done in the Scenario III, and the best agreement between measured and calculated values was obtained for a branching effect of $19 \%$ (Table 4). Apparently, $\delta^{18} \mathrm{O}-\mathrm{N}_{2} \mathrm{O}$ values of the $\mathrm{NO}_{3}{ }^{-}$treatments were dependent on the branching effects, which presumably are different to $\mathrm{NO}_{2}{ }^{-}$reduction. Lower branching effects during $\mathrm{NO}_{3}{ }^{-}$reduction could be caused by lower reaction rates compared to $\mathrm{NO}_{2}{ }^{-}$reduction since the branching is a net isotope effect depending on the balance between diffusive and enzymatic effects (see discussion of $\delta^{15} \mathrm{~N}_{\text {bulk }}$ above).

For $\mathrm{NO}_{3}{ }^{-}$, calculation with Eq. 6 did not have the same precision as compared to $\mathrm{NO}_{2}{ }^{-}$ treatments. This is because $\mathrm{O}$ exchange determined in our previous experiment (Rohe et al., 2014), and $\delta^{18} \mathrm{O}-\mathrm{N}_{2} \mathrm{O}$ measured in the present study, were far more variable in $\mathrm{NO}_{3}{ }^{-}$ treatments. However, varying the total assumed $\mathrm{O}$ exchange did not affect the indication of the enzyme mostly contributing to $\mathrm{O}$ exchange. 
Table 4: Results of modeling oxygen exchange with water during nitrate reduction to $\mathrm{N}_{2} \mathrm{O}$ using Eq. 6. Three scenarios were calculated to assess the fractions of oxygen exchange at $\operatorname{Nar}\left(f_{N a r}\right)$, Nir $\left(f_{N i r}\right)$ and oxygen exchange at Nor $\left(f_{N o r}\right)$ : I. we supposed oxygen exchange only takes place at Nir $\left(f_{\text {Nar }}=0\right.$ and $\mathrm{f}_{\text {Nor }}=0$ ), or II. only at $\operatorname{Nar}\left(\mathrm{f}_{\mathrm{Nir}}=0\right.$ and $\mathrm{f}_{\text {Nor }}=0$ ) or III. measured and modeled $\delta^{18} \mathrm{O}-\mathrm{N}_{2} \mathrm{O}$ values were fitted by adjusting $\mathrm{f}_{\text {Nar }}, \mathrm{f}_{\mathrm{Nir}}$ and $\mathrm{f}_{\text {Nor }}$. Calculated $\delta^{18} \mathrm{O}$ values of $\mathrm{NO}_{2}{ }^{-}$and $\mathrm{N}_{2} \mathrm{O}$ are shown and the goodness of fit is given as difference of measured and calculated $\delta^{18} \mathrm{O}-\mathrm{N}_{2} \mathrm{O}$ (Difference meas.- calc. $\delta^{18} \mathrm{O}$ $\mathrm{N}_{2} \mathrm{O}$ ). Calculations are based on measured $\delta^{18} \mathrm{O}$ values of $\mathrm{NO}$ and $\mathrm{N}_{2} \mathrm{O}$ precursors (22.0 \%o for $\mathrm{NO}_{3}{ }^{-}$; $-9.9 \%$ \% for medium $\mathrm{H}_{2} \mathrm{O}$ of C. lychenicola, F. solani fsp. pisi, F. decemcellulare, and $-8.9 \%$ for medium $\mathrm{H}_{2} \mathrm{O}$ of C. funicola, F. oxysporum and T. hamatum) and on isotope effects according to Casciotti et al. (2007) (branching effect $\varepsilon_{1}$ of Nar with $0 \%$, Nir and Nor each with $30 \%$ and equilibrium effect $\varepsilon_{2}$ of Nar, Nir and Nor with $14 \%$ o). Moreover, $\mathrm{f}_{\text {Nar }}$, $\mathrm{f}_{\text {Nir }}$ and $f_{\text {Nor }}$ assumed in the model scenarios as shown were set to fulfill Eq. 7 using measured values of total oxygen exchange (mean values with standards in brackets) (Rohe et al., 2014).



${ }^{1}$ Data of total $\mathrm{O}$ exchange during denitrification $\left(\mathrm{NO}_{2}{ }^{-}\right.$to $\mathrm{N}_{2} \mathrm{O}$ reduction) were taken from an ${ }^{18} \mathrm{O}$ tracer experiment by Rohe et al. (2014), where the same fungal species were used for incubation studies.

${ }^{2}$ Scenario III: Branching effects $\left(\varepsilon_{1}\right)$ of Nir and Nor were adjusted to 19 \% for calculation for Cy. lichenicola, F. decemcellare, F. oxysporum and T. hamatum; for F. solani fsp. pisi no change was made (30 \%o as in scenario I and II was left). 


\section{$\underline{\text { Conclusions }}$}

We extended the database on the SP fingerprint of $\mathrm{N}_{2} \mathrm{O}$ from pure cultures of fungal denitrifiers from previously two, to now six, fungal species. We confirmed that $\mathrm{N}_{2} \mathrm{O}$ produced by fungi of the order Hypocreales exhibits high and relatively constant SP of $\mathrm{N}_{2} \mathrm{O}$ irrespective of the $\mathrm{N}$ source $\left(\mathrm{NO}_{3}{ }^{-}\right.$or $\left.\mathrm{NO}_{2}{ }^{-}\right)$or species, whereas $C$. funicola of the order Sordariales showed SP $\mathrm{N}_{2} \mathrm{O}$ between the bacterial and Hypcreales SP clusters. The fungus $C$. funicola was clearly different from the five Hypocreales species regarding the $\mathrm{N}_{2} \mathrm{O}$ production, isotopomers and $\mathrm{O}$ exchange, which we determined in a previous experiment (Rohe et al., 2014). To our knowledge information about differences in physiology (incl. enzymes involved in denitrification) between both fungal orders is lacking. Until now P450nor was identified only in Hypocreales species. Our results from Hypocreales species confirm the possibility to use SP of $\mathrm{N}_{2} \mathrm{O}$ to differentiate between $\mathrm{N}_{2} \mathrm{O}$ from denitrification by bacterial and by certain fungal groups. However, this cannot be extended to fungal denitrification in general without knowing the significance of fungal orders other than Hypocreales to soil $\mathrm{N}_{2} \mathrm{O}$ fluxes.

The control of $\delta^{15} \mathrm{~N}_{\text {bulk }}$ of the fungal pure cultures is similar to bacteria and whole soil communities with net $\mathrm{N}$ isotope effects increasing with $\mathrm{N}_{2} \mathrm{O}$ production rates. This further confirms that $\delta^{15} \mathrm{~N}_{\text {bulk }}$ is a poor estimator of microbial pathways.

The control of $\delta^{18} \mathrm{O}-\mathrm{N}_{2} \mathrm{O}$ of fungal $\mathrm{N}_{2} \mathrm{O}$ largely depends on $\mathrm{O}$ exchange between $\mathrm{H}_{2} \mathrm{O}$ and denitrification intermediates, which is similar to bacteria. Our data provide first evidence on the share of individual reduction steps where $\mathrm{O}$ exchange occurs in fungal pure cultures, suggesting that $\mathrm{O}$ exchange is predominantly associated with $\mathrm{Nir}$ for Hypocreales and with Nor for Sordariales. These findings help to better understand variations in $\delta^{18} \mathrm{O}-\mathrm{N}_{2} \mathrm{O}$ of soil emitted $\mathrm{N}_{2} \mathrm{O}$ and thus improve estimation of $\mathrm{N}_{2} \mathrm{O}$ process dynamics based on $\mathrm{N}_{2} \mathrm{O}$ isotopologues.

We confirm SP as a promising approach to differentiate between $\mathrm{N}_{2} \mathrm{O}$ produced by fungal and bacterial denitrification, but also identified the need to check the relevance of denitrifying fungi with lower SP in future studies as well as SP of fungal $\mathrm{N}_{2} \mathrm{O}$ from intact microbial soil communities. 


\section{Acknowledgements}

Susanne Behn is thanked for assistance with microbial work and Martina Heuer for isotopic analysis; the Max-Planck Institute for Terrestrial Microbiology in Marburg (Germany) for providing the fungal strains and the possibility to work in their lab and Roland Fuß for help with statistical analysis. We would like to thank Dina Führmann for editing the English.

This joint research project was financially supported by the State of Lower-Saxony and the Volkswagen Foundation, Hanover, Germany.

\section{References}

Aerssens, E., Tiedje, J.M., Averill, B.A., 1986. Isotope Labeling Studies on the Mechanisms of N-bond Formation in Denitrification. Journal of Biological Chemistry 261, 96529656.

Barford, C.C., Montoya, J.P., Altabet, M.A., Mitchell, R., 1999. Steady-State Nitrogen Isotope Effects of $\mathrm{N}_{2}$ and $\mathrm{N}_{2} \mathrm{O}$ Production in Paracoccus denitrificans. Applied and Environmental Microbiology 65, 989-994.

Blagodatskaya, E., Dannenmann, M., Gasche, R., Butterbach-Bahl, K., 2010. Microclimate and forest management alter fungal-to-bacterial ratio and $\mathrm{N}_{2} \mathrm{O}$-emission during rewetting in the forest floor and mineral soil of mountainous beech forests. Biogeochemistry 97, 55-70.

Bollag, J.M., Tung, G., 1972. Nitrous oxide release by soil fungi. Soil Biology and Biochemistry 4, 271-276.

Braker, G., Conrad, R., 2011. Diversity, Structure, and Size of $\mathrm{N}_{2} \mathrm{O}$-Producing Microbial Communities in Soils-What Matters for Their Functioning?, In: Laskin, A.I., Sariaslani, S., Gadd, G.M. (Eds.), Advances in Applied Microbiology, Vol 75, pp. 3370.

Brand, W.A., 1995. Precon: A Fully Automated Interface for the Pre-GC Cocentration of Trace Gases in Air for Isotopic Analysis. Isotopes in Environmental and Health Studies 31, 277-284.

Casciotti, K.L., Böhlke, J.K., McIlvin, M.R., Mroczkowski, S.J., Hannon, J.E., 2007. Oxygen Isotopes in Nitrite: Analysis, Calibration, and Equilibration. Analytical Chemistry 79, 2427-2436.

Casciotti, K.L., McIlvin, M.R., 2007. Isotopic analyses of nitrate and nitrite from reference mixtures and application to Eastern Tropical North Pacific waters. Marine Chemistry 107, 184-201.

Casciotti, K.L., Sigman, D.M., Hastings, M.G., Böhlke, J.K., Hilkert, A., 2002. Measurement of the Oxygen Isotopic Composition of Nitrate in Seawater and Freshwater Using the Denitrifier Method. Analytical Chemistry 74, 4905-4912.

Crenshaw, C.L., Lauber, C., Sinsabaugh, R.L., Stavely, L.K., 2008. Fungal control of nitrous oxide production in semiarid grassland. Biogeochemistry 87, 17-27.

Davidson, E.A., Firestone, M.K., 1988. Measurement of Nitrous Oxide Dissolved in Soil Solution. Soil Science Society of America Journal 52, 1201-1203. 
Domsch, K.H., Gams, W., Anderson, T.H., 1980. Compendium of soil fungi. Volumes 1 and 2. Academic Press Ltd., London, UK, vii + 859 pp.

Farquhar, G., O'Leary, M., Berry, J., 1982. On the Relationship Between Carbon Isotope Discrimination and the Intercellular Carbon Dioxide Concentration in Leaves. Functional Plant Biology 9, 121-137.

Frame, C.H., Casciotti, K.L., 2010. Biogeochemical controls and isotopic signatures of nitrous oxide production by a marine ammonia-oxidizing bacterium. Biogeosciences 7, 2695-2709.

Garber, E.A., Hollocher, T.C., 1982. ${ }^{15} \mathrm{~N},{ }^{18} \mathrm{O}$ tracer studies on the activation of nitrite by denitrifying bacteria. Nitrite/water-oxygen exchange and nitrosation reactions as indicators of electrophilic catalysis. Journal of Biological Chemistry 257, 8091-8097.

Granger, J., Sigman, D.M., Lehmann, M.F., Tortell, P.D., 2008. Nitrogen and oxygen isotope fractionation during dissimilatory nitrate reduction by denitrifying bacteria. Limnology and Oceanography 53, 2533-2545.

Hayatsu, M., Tago, K., Saito, M., 2008. Various players in the nitrogen cycle: Diversity and functions of the microorganisms involved in nitrification and denitrification. Soil Science \& Plant Nutrition 54, 33-45.

IPCC, 2013. Climate Change 2013: The Physical Science Basis. Contribution of Working Group I to the Fifth Assessment Report of the Intergovernmental Panel on Climate Change, In: Stocker, T.F., Qin, D., Plattner, G.-K., Tignor, M., Allen, S.K., Boschung, J., Nauels, A., Xia, Y., Bex, V., Midgley, P.M. (Eds.), Cambridge, United Kingdom and New York, NY, USA, p. 1535 pp.

Kendall, C., 1998. Tracing Nitrogen Sources and Cycling in Catchments, In: McDonnell, J.J., Kendall, C. (Eds.), Isotope Tracers in Catchment Hydrology Elsevier Science B.V., Amsterdam, pp. 519-576.

Kim, S.W., Fushinobu, S., Zhou, S.M., Wakagi, T., Shoun, H., 2009. Eukaryotic nirK Genes Encoding Copper-Containing Nitrite Reductase: Originating from the Protomitochondrion? Applied and Environmental Microbiology 75, 2652-2658.

Knowles, R., 1982. Denitrification. Microbiological Reviews 46, 43-70.

Kool, D.M., Müller, C., Wrage, N., Oenema, O., Van Groenigen, J.W., 2009. Oxygen exchange between nitrogen oxides and $\mathrm{H}_{2} \mathrm{O}$ can occur during nitrifier pathways. Soil Biology and Biochemistry 41, 1632-1641.

Kool, D.M., Van Groenigen, J.W., Wrage, N., 2011. Source dertermination of Nitrous Oxide based on Nitrogen and Oxygen Isotopes tracing: Dealing with Oxygen Exchange, In: Klotz, M.G., Stein, L.Y. (Eds.), Methods in Enzymology, Vol 46: Research on Nitrification and Related Processes, Pt B, pp. 139-160.

Köster, J.R., Well, R., Tuzson, B., Bol, R., Dittert, K., Giesemann, A., Emmenegger, L., Manninen, A., Cárdenas, L., Mohn, J., 2013. Novel laser spectroscopic technique for continuous analysis of $\mathrm{N}_{2} \mathrm{O}$ isotopomers - application and intercomparison with isotope ratio mass spectrometry. Rapid Communications in Mass Spectrometry 27, 216-222.

Laughlin, R.J., Stevens, R.J., 2002. Evidence for Fungal Dominance of Denitrification and Codenitrification in a Grassland Soil. Soil Science Society of America Journal 66, 1540-1548.

Long, A., Heitman, J., Tobias, C., Philips, R., Song, B., 2013. Co-Occurring Anammox, Denitrification, and Codenitrification in Agricultural Soils. Applied and Environmental Microbiology 79, 168-176.

Mariotti, A., Germon, J.C., Leclerc, A., 1982. Nitrogen Isotope Fractionation associated with the $\mathrm{NO}_{2}{ }^{-}-\mathrm{N}_{2} \mathrm{O}$ step Of Denitrification in Soils. Canadian Journal of Soil Science 62, 227-241. 
Mariotti, A., Landreau, A., Simon, B., 1988. ${ }^{15} \mathrm{~N}$ isotope biogeochemistry and natural denitrification process in groundwater: Application to the chalk aquifer of northern France. Geochimica et Cosmochimica Acta 52, 1869-1878.

McLain, J.E.T., Martens, D.A., 2006. $\mathrm{N}_{2} \mathrm{O}$ production by heterotrophic $\mathrm{N}$ transformations in a semiarid soil. Applied Soil Ecology 32, 253-263.

Ostrom, N., Ostrom, P., 2011. The Isotopomers of Nitrous Oxide: Analytical Considerations and Application to Resolution of Microbial Production Pathways, In: Baskaran, M. (Ed.), Handbook of Environmental Isotope Geochemistry. Springer Berlin Heidelberg, pp. 453-476.

Perez, T., Garcia-Montiel, D., Trumbore, S., Tyler, S., De Camargo, P., Moreira, M., Piccolo, M., Cerri, C., 2006. Nitrous oxide nitrification and denitrification ${ }^{15} \mathrm{~N}$ enrichment factors from Amazon forest soils. Ecological Applications 16, 2153-2167.

R Core Team, 2013. R: A language and environment for statistical computing. R Foundation for Statistical Computing. R Foundation for Statistical Computing, Vienna, Austria.

Richardson, D., Felgate, H., Watmough, N., Thomson, A., Baggs, E., 2009. Mitigating release of the potent greenhouse gas $\mathrm{N}_{2} \mathrm{O}$ from the nitrogen cycle - could enzymic regulation hold the key? Trends in Biotechnology 27, 388-397.

Rohe, L., Anderson, T.-H., Braker, G., Flessa, H., Giesemann, A., Wrage-Mönnig, N., Well, R., 2014. Fungal oxygen exchange between denitrification intermediates and water. Rapid Communications in Mass Spectrometry 28, 377-384.

Ruzicka, S., Edgerton, D., Norman, M., Hill, T., 2000. The utility of ergosterol as a bioindicator of fungi in temperate soils. Soil Biology and Biochemistry 32, 989-1005.

Santoro, A.E., Buchwald, C., McIlvin, M.R., Casciotti, K.L., 2011. Isotopic Signature of $\mathrm{N}_{2} \mathrm{O}$ Produced by Marine Ammonia-Oxidizing Archaea. Science 333, 1282-1285.

Schmidt, H.L., Werner, R.A., Yoshida, N., Well, R., 2004. Is the isotopic composition of nitrous oxide an indicator for its origin from nitrification or denitrification? A theoretical approach from referred data and microbiological and enzyme kinetic aspects. Rapid Communications in Mass Spectrometry 18, 2036-2040.

Shoun, H., Fushinobu, S., Jiang, L., Kim, S.W., Wakagi, T., 2012. Fungal denitrification and nitric oxide reductase cytochrome P450nor. Philosophical Transactions of the Royal Society B-Biological Sciences 367, 1186-1194.

Shoun, H., Kim, D.-H., Uchiyama, H., Sugiyama, J., 1992. Denitrification by fungi. FEMS Microbiology Letters 94, 277-281.

Shoun, H., Tanimoto, T., 1991. Denitrification by the fungus Fusarium oxysporum and involvement of cytochrome $\mathrm{P}-450$ in the respiratory nitrite reduction. Journal of Biological Chemistry 266, 11078-11082.

Snider, D.M., Schiff, S.L., Spoelstra, J., 2009. ${ }^{15} \mathrm{~N} /{ }^{14} \mathrm{~N}$ and ${ }^{18} \mathrm{O} /{ }^{16} \mathrm{O}$ stable isotope ratios of nitrous oxide produced during denitrification in temperate forest soils. Geochimica et Cosmochimica Acta 73, 877-888.

Snider, D.M., Spoelstra, J., Schiff, S.L., Venkiteswaran, J.J., 2010. Stable Oxygen Isotope Ratios of Nitrate Produced from Nitrification: ${ }^{18} \mathrm{O}$-Labeled Water Incubations of Agricultural and Temperate Forest Soils. Environmental Science \& Technology 44, 5358-5364.

Snider, D.M., Venkiteswaran, J.J., Schiff, S.L., Spoelstra, J., 2012. Deciphering the oxygen isotope composition of nitrous oxide produced by nitrification. Global Change Biology 18, 356-370.

Snider, D.M., Venkiteswaran, J.J., Schiff, S.L., Spoelstra, J., 2013. A new mechanistic model of $\delta^{18} \mathrm{O}-\mathrm{N}_{2} \mathrm{O}$ formation by denitrification. Geochimica et Cosmochimica Acta 112, $102-115$. 
Sutka, R.L., Adams, G.C., Ostrom, N.E., Ostrom, P.H., 2008. Isotopologue fractionation during $\mathrm{N}_{2} \mathrm{O}$ production by fungal denitrification. Rapid Communications in Mass Spectrometry 22, 3989-3996.

Sutka, R.L., Ostrom, N.E., Ostrom, P.H., Breznak, J.A., Gandhi, H., Pitt, A.J., Li, F., 2006. Distinguishing Nitrous Oxide Production from Nitrification and Denitrification on the Basis of Isotopomer Abundances. Applied and Environmental Microbiology 72, 638644.

Thomson, A.J., Giannopoulos, G., Pretty, J., Baggs, E.M., Richardson, D.J., 2012. Biological sources and sinks of nitrous oxide and strategies to mitigate emissions. Philosophical Transactions of the Royal Society B-Biological Sciences 367, 1157-1168.

Toyoda, S., Mutobe, H., Yamagishi, H., Yoshida, N., Tanji, Y., 2005. Fractionation of $\mathrm{N}_{2} \mathrm{O}$ isotopomers during production by denitrifier. Soil Biology and Biochemistry 37, 1535-1545.

Toyoda, S., Yoshida, N., 1999. Determination of nitrogen isotopomers of nitrous oxide on a modified isotope ratio mass spectrometer. Analytical Chemistry 71, 4711-4718.

Toyoda, S., Yoshida, N., Miwa, T., Matsui, Y., Yamagishi, H., Tsunogai, U., Nojiri, Y., Tsurushima, N., 2002. Production mechanism and global budget of $\mathrm{N}_{2} \mathrm{O}$ inferred from its isotopomers in the western North Pacific. Geophysical Research Letters 29, 7-1-74.

Well, R., Eschenbach, W., Flessa, H., von der Heide, C., Weymann, D., 2012. Are dual isotope and isotopomer ratios of $\mathrm{N}_{2} \mathrm{O}$ useful indicators for $\mathrm{N}_{2} \mathrm{O}$ turnover during denitrification in nitrate-contaminated aquifers? Geochimica et Cosmochimica Acta 90, 265-282.

Well, R., Flessa, H., 2008. Isotope fractionation factors of $\mathrm{N}_{2} \mathrm{O}$ diffusion. Rapid Communications in Mass Spectrometry 22, 2621-2628.

Well, R., Flessa, H., 2009. Isotopologue signatures of $\mathrm{N}_{2} \mathrm{O}$ produced by denitrification in soils. Journal of Geophysical Research: Biogeosciences 114, G02020.

Wrage, N., van Groenigen, J.W., Oenema, O., Baggs, E.M., 2005. A novel dual-isotope labelling method for distinguishing between soil sources of $\mathrm{N}_{2} \mathrm{O}$. Rapid Communications in Mass Spectrometry 19, 3298-3306.

Ye, R.W., Toro-Suarez, I., Tiedje, J.M., Averill, B.A., 1991. $\mathrm{H}_{2}{ }^{18} \mathrm{O}$ isotope exchange studies on the mechanism of reduction of nitric oxide and nitrite to nitrous oxide by denitrifying bacteria. Evidence for an electrophilic nitrosyl during reduction of nitric oxide. Journal of Biological Chemistry 266, 12848-12851.

Yoshida, N., 1988. ${ }^{15} \mathrm{~N}$-depleted $\mathrm{N}_{2} \mathrm{O}$ as a product of nitrification. Nature 335, 528-529. 


\section{Comparing modified substrate induced respiration with selective inhibition (SIRIN) and $\mathrm{N}_{2} \mathrm{O}$ isotope methods to estimate $\mathrm{N}_{2} \mathrm{O}$ production of fungal denitrification in three arable soils}

This chapter is currently prepared to be submitted.

Rohe, L., Anderson, T.-H., Flessa, H., Giesemann, G., Lewicka-Szczebak, D., Wrage-Mönnig, N., Well, R.

\section{$\underline{\text { Abstract }}$}

RATIONALE: Pure culture studies gave evidence on the ability of soil fungi to produce $\mathrm{N}_{2} \mathrm{O}$ during denitrification. Soil studies with selective inhibition indicated a dominance of fungal compared to bacterial $\mathrm{N}_{2} \mathrm{O}$ production in soil, which recently drew more attention to fungal denitrification. Analyzing the isotopic composition of $\mathrm{N}_{2} \mathrm{O}$, especially the ${ }^{15} \mathrm{~N}$ site preference (SP) of $\mathrm{N}_{2} \mathrm{O}$, showed that $\mathrm{N}_{2} \mathrm{O}$ from pure bacterial or fungal cultures differed in SP values, which might enable it to quantify fungal $\mathrm{N}_{2} \mathrm{O}$ based on the isotopic endmember signatures of $\mathrm{N}_{2} \mathrm{O}$ produced by fungi and bacteria.

METHODS: Three different soils were incubated under denitrifying conditions using a modification of the substrate induced respiration with selective inhibition (SIRIN) to analyze $\mathrm{N}_{2} \mathrm{O}$ evolved from selective organism groups. $\mathrm{N}_{2} \mathrm{O}$ reduction was quantified by ${ }^{15} \mathrm{~N}$ tracer application. The effect of $\mathrm{N}_{2} \mathrm{O}$ reduction on $\mathrm{N}_{2} \mathrm{O}$ production and the isotopic signature of $\mathrm{N}_{2} \mathrm{O}$ were determined by parallel varieties with and without acetylene to block the $\mathrm{N}_{2} \mathrm{O}$ reduction. RESULTS: In this study a low contribution of up to $22 \%$ of fungal denitrification was observed with an isotope endmember mixing approach (IEM). Quantifying the fungal fraction with modified SIRIN was only possible in one soil. This soil showed a fungal fraction of about $28 \%$, which was similar to the results obtained by IEM.

DISCUSSION: This study was the first attempt to quantify the fungal contribution on $\mathrm{N}_{2} \mathrm{O}$ production during denitrification by simultaneous application of two approaches, i.e. selective inhibition of microbial growth and SP of $\mathrm{N}_{2} \mathrm{O}$. There were indications that fungi played only a minor role in $\mathrm{N}_{2} \mathrm{O}$ production from soils. Nevertheless, reliable methods, which are validated to quantify fungal contribution on $\mathrm{N}_{2} \mathrm{O}$ production from soil are still lacking.

Keywords: selective growth inhibition, ${ }^{15} \mathrm{~N}$ site preference, fungal denitrification, $\mathrm{C}_{2} \mathrm{H}_{2}$ 


\section{$\underline{\text { Introduction }}$}

The greenhouse gas nitrous oxide $\left(\mathrm{N}_{2} \mathrm{O}\right)$ contributes to global warming and to the depletion of the ozone layer in the stratosphere (IPCC, 2013). The highest anthropogenic $\mathrm{N}_{2} \mathrm{O}$ emissions originate from agricultural soils and are mainly produced during microbial nitrification, nitrifier dentirification and denitrification (Bremner, 1997; Firestone and Davidson, 1989; IPCC, 2013; Wrage et al., 2005). In order to find mitigation strategies for $\mathrm{N}_{2} \mathrm{O}$ emissions from arable soils, it is important to understand $\mathrm{N}_{2} \mathrm{O}$ sources and sinks and thus knowledge about the production pathways and the microorganisms involved has to be improved. For a long time, it was believed that solely bacteria are involved in $\mathrm{N}_{2} \mathrm{O}$ formation during denitrification (Firestone and Davidson, 1989); however, also several fungi are capable of denitrification (Bollag and Tung, 1972; Shoun et al., 1992). Denitrification describes the reduction of nitrate $\left(\mathrm{NO}_{3}{ }^{-}\right)$to dinitrogen $\left(\mathrm{N}_{2}\right)$, with the intermediates nitrite $\left(\mathrm{NO}_{2}{ }^{-}\right)$, nitric oxide (NO) and $\mathrm{N}_{2} \mathrm{O}$ (Knowles, 1982). While this entire reaction chain including the ability to reduce $\mathrm{N}_{2} \mathrm{O}$ to $\mathrm{N}_{2}$ is found among bacterial denitrifiers, most fungi lack $\mathrm{N}_{2} \mathrm{O}$ reductase (Nos) (Shoun et al., 1992). To which part different microbial groups contribute to $\mathrm{N}_{2} \mathrm{O}$ emissions from soil is not yet sufficiently investigated. In general fungi dominate the biomass in soil (up to 96\%) compared to bacteria and thus fungi could potentially play a dominant role in $\mathrm{N}_{2} \mathrm{O}$ production (Braker and Conrad, 2011; Ruzicka et al., 2000). Furthermore, a respiratory fungal-to-bacterial (F:B) ratio of 4 is typical for arable soils (Anderson and Domsch, 1975; Blagodatskaya and Anderson, 1998). The high fungal abundance in soil and the fact that $\mathrm{N}_{2} \mathrm{O}$ is the major end product of fungal denitrification lead to the assumption that the potential activity of fungal $\mathrm{N}_{2} \mathrm{O}$ production in soil may exceed the bacterial production, provided that both microbial groups have the same specific $\mathrm{N}_{2} \mathrm{O}$ production (Shoun et al., 1992; Sutka et al., 2008). However, until now reliable methods for distinguishing between fungal and bacterial $\mathrm{N}_{2} \mathrm{O}$ emissions from an indigenous soil community are lacking.

Soil incubation experiments could serve to differentiate between $\mathrm{N}_{2} \mathrm{O}$ produced by fungi and bacteria during denitrification by the application of two antibiotics: streptomycin and cycloheximide, which inhibit bacterial or fungal growth, respectively, by inhibition of the protein biosynthesis and this method is known as substrate induced respiration with selective inhibition (SIRIN) (Anderson and Domsch, 1975; Blagodatskaya et al., 2010; Crenshaw et al., 2008; Laughlin and Stevens, 2002; Long et al., 2013). A few studies used a modification of this method for $\mathrm{N}_{2} \mathrm{O}$ analysis and found a greater decrease of $\mathrm{N}_{2} \mathrm{O}$ production with fungal than with bacterial growth inhibition (e.g. 89 vs. 23\% decrease (Laughlin and Stevens, 2002)), indicating that fungi might dominate $\mathrm{N}_{2} \mathrm{O}$ production (Blagodatskaya et al., 2010; Crenshaw 
et al., 2008; Laughlin and Stevens, 2002; Long et al., 2013; McLain and Martens, 2006). Additionally to denitrification, Tanimoto et al. (1992) found some fungi capable of codenitrification, where one $\mathrm{N}$ atom from $\mathrm{NO}_{2}{ }^{-}$is combined with an $\mathrm{N}$ atom from compounds like azide or ammonium $\left(\mathrm{NH}_{4}{ }^{+}\right)$for $\mathrm{N}_{2} \mathrm{O}$ production (Garber and Hollocher, 1982; Shoun et al., 1992; Spott et al., 2011; Tanimoto et al., 1992). Incubation experiments with a grassland soil under anaerobic conditions using stable isotope tracing to differentiate between sources of $\mathrm{N}_{2} \mathrm{O}$ indicated a contribution of codenitrification of about $92 \%$ of $\mathrm{N}_{2} \mathrm{O}$ produced (Laughlin and Stevens, 2002). This again stresses the large potential $\mathrm{N}_{2} \mathrm{O}$ production by fungi.

Analyzing the isotopic composition of $\mathrm{N}_{2} \mathrm{O}$ might be a promising tool to distinguish between $\mathrm{N}_{2} \mathrm{O}$ from bacterial and fungal denitrification. Especially, the isotopomer ratios of $\mathrm{N}_{2} \mathrm{O}$ in pure culture studies showed differences in $\mathrm{N}_{2} \mathrm{O}$ from bacterial and fungal denitrification (Frame and Casciotti, 2010; Rohe et al., 2014a; Sutka et al., 2008; Sutka et al., 2006) and might be suitable to distinguish between $\mathrm{N}_{2} \mathrm{O}$ produced by bacteria or fungi under denitrifying conditions. Isotopomer ratios of $\mathrm{N}_{2} \mathrm{O}$ can be expressed as ${ }^{15} \mathrm{~N}$ site preference (SP), i.e. the difference between $\delta^{15} \mathrm{~N}$ of the central and terminal $\mathrm{N}$-position of the asymmetric $\mathrm{N}_{2} \mathrm{O}$ molecule (Toyoda and Yoshida, 1999). The SP of $\mathrm{N}_{2} \mathrm{O}$ from six pure fungal cultures was between 20 and $37 \%$ (Rohe et al., 2014a; Sutka et al., 2008), whereas several bacteria produced $\mathrm{N}_{2} \mathrm{O}$ with a SP between -11 and 0 \%o during denitrification (Frame and Casciotti, 2010; Sutka et al., 2006). However, SP of $\mathrm{N}_{2} \mathrm{O}$ produced by pure bacterial cultures during nitrification is approximately $33 \%$ and interferes with SP of $\mathrm{N}_{2} \mathrm{O}$ from fungal denitrification (Rohe et al., 2014a; Sutka et al., 2008; Sutka et al., 2006). This demonstrates the difficulty to use $\mathrm{SP}$ of $\mathrm{N}_{2} \mathrm{O}$ as an indicator for different organism groups contributing to $\mathrm{N}_{2} \mathrm{O}$ production from soil, where different pathways may co-occur. Although SP values of $\mathrm{N}_{2} \mathrm{O}$ are independent of isotopic signatures of the precursors, $\delta^{15} \mathrm{~N}$ and $\delta^{18} \mathrm{O}$ values of produced $\mathrm{N}_{2} \mathrm{O}$ result from the isotopic signature of the precursor and isotopic fractionation during the $\mathrm{N}_{2} \mathrm{O}$ production (Frame and Casciotti, 2010; Toyoda et al., 2005). Interpretation of $\delta^{18} \mathrm{O}$ of $\mathrm{N}_{2} \mathrm{O}$ is even more complex, because $\mathrm{O}$ exchange during denitrification between water and denitrification intermediates alters the final $\delta^{18} \mathrm{O}$ value (Aerssens et al., 1986; Garber and Hollocher, 1982; Kool et al., 2007; Rohe et al., 2014b). Moreover, $\delta^{15} \mathrm{~N}, \delta^{18} \mathrm{O}$ and SP values of $\mathrm{N}_{2} \mathrm{O}$ produced in the course of denitrification are affected by isotopic fractionation due to $\mathrm{N}_{2} \mathrm{O}$ reduction. During the $\mathrm{N}_{2} \mathrm{O}$ reduction step, the ${ }^{14} \mathrm{~N}^{16} \mathrm{O}$ bond is preferentially broken compared to ${ }^{14} \mathrm{~N}^{18} \mathrm{O}$ or ${ }^{15} \mathrm{~N}^{16} \mathrm{O}$, resulting in residual $\mathrm{N}_{2} \mathrm{O}$, which is relatively isotopically enriched in ${ }^{15} \mathrm{~N}$ and ${ }^{18} \mathrm{O}$ and shows higher SP values of $\mathrm{N}_{2} \mathrm{O}$ compared to SP of $\mathrm{N}_{2} \mathrm{O}$ from denitrification without the reduction step (Ostrom et al., 2007; Popp et al., 2002). 
Consequently, the $\mathrm{N}_{2} \mathrm{O}$ reduction inhibition method with acetylene $\left(\mathrm{C}_{2} \mathrm{H}_{2}\right)$ (Groffman et al., 2006; Yoshinari and Knowles, 1976) should result in lower SP values of $\mathrm{N}_{2} \mathrm{O}$ produced in laboratory studies (Lewicka-Szczebak et al., 2014). Quantification of $\mathrm{N}_{2} \mathrm{O}$ reduction to $\mathrm{N}_{2}$ during denitrification is possible by analysing ${ }^{15} \mathrm{~N}_{2}$ fluxes in ${ }^{15} \mathrm{~N}$ tracing experiments (Lewicka-Szczebak et al., 2014; Well et al., 2006).

Based on the above cited ranges for the isotopomer endmembers of fungal and bacterial denitrification, and assuming that only fungi and bacteria are responsible for $\mathrm{N}_{2} \mathrm{O}$ production the fraction of fungal $\mathrm{N}_{2} \mathrm{O}$ can be calculated from SP of $\mathrm{N}_{2} \mathrm{O}$ produced in soil ( $\mathrm{SP}_{\text {prod }}$ ), provided there is no $\mathrm{N}_{2} \mathrm{O}$ reduction occurring, which is altering SP of emitted $\mathrm{N}_{2} \mathrm{O}$ (Ostrom and Ostrom, 2011; Ostrom et al., 2010). Inhibiting $\mathrm{N}_{2} \mathrm{O}$ reduction with $\mathrm{C}_{2} \mathrm{H}_{2}$ during anaerobic incubation of soils is a means to determine SP $_{\text {prod }}$ (Lewicka-Szczebak et al., 2014; Well and Flessa, 2009). Hence $\mathrm{C}_{2} \mathrm{H}_{2}$ inhibition might be suitable to quantify $\mathrm{SP}_{\text {prod }}$ in soils exhibiting significant $\mathrm{N}_{2} \mathrm{O}$ reduction without inhibiting the $\mathrm{N}_{2} \mathrm{O}$ reduction and thus allow quantification of fungal $\mathrm{N}_{2} \mathrm{O}$ fluxes based on $\mathrm{SP}_{\text {prod }}$.

The study aims at determining the fungal contribution on $\mathrm{N}_{2} \mathrm{O}$ production from denitrification in three arable soils. The second aim is to compare the fungal contribution on $\mathrm{N}_{2} \mathrm{O}$ production determined from a modified SIRIN and the isotope endmember mixing approach and thus assess factors of potential bias of both methods. The third aim is to determine SP of $\mathrm{N}_{2} \mathrm{O}$ fluxes from fungal soil communities and thus to evaluate the transferability of the pure culture range of the fungal SP endmember.

\section{Materials and Methods}

\section{Soil samples}

As experiments were conducted with three soils, but one soil from two different sampling times, we named the experiments: Soil sampling of the loamy sand was done in December 2012 (Experiment 1), of the sand in January 2013 (Experiment 2), of the silt loam in December 2012 (Experiment 3), and of loamy sand in June 2011 (Experiment 4). For further characteristics of the soils, see Table 1 . Soil samples of the upper $30 \mathrm{~cm}$ were collected in plastic bags with cotton wool stoppers and stored at $6{ }^{\circ} \mathrm{C}$ for maximally two months. To get information about the initial soil status, total contents of $\mathrm{C}$ and $\mathrm{N}$ in soil samples were analyzed by dry combustion of grinded samples (LECO TruSpec, Germany). The soil pH was

measured in $0.01 \mathrm{M} \mathrm{CaCl}_{2}$. The mineral nitrogen content (Nmin) of soil samples was determined before and after fertilization by extracting $\mathrm{NO}_{3}{ }^{-}$and $\mathrm{NH}_{4}{ }^{+}$with $0.01 \mathrm{M}$ calcium chloride dihydrate $\left(\mathrm{CaCl}_{2} \cdot 2 \mathrm{H}_{2} \mathrm{O}\right)$ according to ISO 14255 and analyzing $\mathrm{NO}_{3}{ }^{-}$and $\mathrm{NH}_{4}{ }^{+}$ 
concentrations in the extracts with a Continuous-Flow-Analyzer (SKALAR, Germany). The $\delta^{15} \mathrm{~N}$ and $\delta^{18} \mathrm{O}$ values of $\mathrm{NO}_{3}{ }^{-}$and $\mathrm{NO}_{2}{ }^{-}$in soil extracts (with $0.01 \mathrm{M}$ calcium chloride dihydrate $\left(\mathrm{CaCl}_{2} \cdot 2 \mathrm{H}_{2} \mathrm{O}\right)$ ) were analyzed by the bacterial denitrifier method (Casciotti et al., 2002). Respiratory biomass of the three soils was analyzed with substrate induced respiration (SIR) according to Anderson and Domsch (1978) and the respiratory F:B ratio was analyzed with substrate induced respiration with selective inhibition (SIRIN) in summer 2010 by a computer-generated selectivity analysis: "SIR-SBA 4.00” (Heinemeyer, copyright MasCo Analytik, Hildesheim, Germany) (SIRIN; Anderson and Domsch, 1975). The scheme of glucose and growth inhibitor combinations is listed below in section "Methodological approach”.

\section{Methodological approach}

\section{SIRIN pre-experiment:}

To determine the fungal impact on $\mathrm{N}_{2} \mathrm{O}$ emissions from soil we conducted a pre-experiment, in order to get information about optimal substrate and inhibitor concentrations for substrate induced growth inhibition. The method of substrate induced respiration (SIR) (Anderson and Domsch, 1978) was used to get information about the amount of respiratory biomass in soil. To this end, we added different concentrations of glucose $(0.50,0.75,1.0,1.5,2.0,3.0,4.0$, 5.0, $6.0 \mathrm{mg} \mathrm{g}^{-1}$ dry weight ( $\left.\mathrm{dw}\right)$ soil) to find the optimal glucose concentration ( $\mathrm{c}_{\mathrm{opt}}$ (glucose)), which is the glucose concentration that causes maximum initial respiration rates (Anderson and Domsch, 1978). $\mathrm{C}_{\text {opt }}$ (glucose)) was $1.0 \mathrm{mg} \mathrm{g}^{-1}$ for Experiment 2 (sand) and $1.5 \mathrm{mg} \mathrm{g}^{-1}$ for Experiments 1, 3 and 4 (loamy sand and silt loam). Glucose served as substrate to initiate microbial growth. Then, for determining the respiratory F:B ratios the selective inhibition method (SIRIN) of Anderson and Domsch (1975) was applied.

We conducted SIRIN according to Anderson and Domsch (1975). Selectivity of the inhibitor combinations of streptomycin (bacterial respiratory inhibitor) and cycloheximide (fungal respiratory inhibitor) were tested with the following concentrations, 0.75, 1.0, $1.5 \mathrm{mg} \mathrm{gdw}^{-1}$, respectively. The optimal concentration of inhibition of fungal respiratory was $0.75 \mathrm{mg} \mathrm{gdw}^{-1}$ soil cycloheximide ( $\mathrm{c}_{\text {opt }}$ (cycloheximide)) and for bacterial respiratory inhibition $1.0 \mathrm{mg} \mathrm{gdw}^{-1}$ soil streptomycin ( $\left.\mathrm{c}_{\mathrm{opt}}(\mathrm{streptomycin})\right)$. 
Table 1: Soil characteristics of three arable soils from Germany used for incubation experiments (standard deviation in brackets).

\begin{tabular}{|c|c|c|c|c|c|c|c|c|c|c|}
\hline Soil texture & Location & $\begin{array}{c}\text { C content } \\
{[\%]}\end{array}$ & $\begin{array}{c}\text { N content } \\
{[\%]}\end{array}$ & $\begin{array}{l}\mathrm{NH}_{4}{ }^{+}-\mathrm{N} \\
{\left[\mathrm{mg} \mathrm{L}^{-1}\right]}\end{array}$ & $\begin{array}{l}\mathrm{NO}_{3}{ }^{-}-\mathrm{N} \\
{\left[\mathrm{mg} \mathrm{L}^{-1}\right]}\end{array}$ & $\begin{array}{c}\mathrm{pH} \\
\left(\mathrm{CaCl}_{2}\right)\end{array}$ & $\begin{array}{c}\delta^{15} \mathrm{~N}_{-}^{-} \\
\mathrm{NO}_{3}^{-} \\
{[\% \mathrm{o}]}\end{array}$ & $\begin{array}{c}\delta^{18} \mathrm{O}_{-}^{-} \\
\mathrm{NO}_{3}^{-} \\
{[\% \text { ] }}\end{array}$ & $\begin{array}{c}\text { Resp. } \\
\text { F:B } \\
\text { ratio }\end{array}$ & $\begin{array}{c}\text { Resp. } \\
\text { Biomass } \\
{\left[\mu \mathrm{C} \mathrm{gdw}^{-1}\right.} \\
\text { soill }]\end{array}$ \\
\hline Loamy sand & Braunschweig $^{\mathrm{a}}$ & $\begin{array}{c}1.43 \\
(<0.01)\end{array}$ & $\begin{array}{c}0.10 \\
(<0.01)\end{array}$ & 0.04 & 1.25 & 5.67 & 3.98 & -4.82 & 2.6 & 234 \\
\hline Sand & Wennebostel $^{\mathrm{b}}$ & $\begin{array}{c}2.31 \\
(0.04)\end{array}$ & $\begin{array}{c}0.14 \\
(<0.01)\end{array}$ & 0.02 & 0.56 & 5.54 & 0.73 & -2.68 & 2.6 & 161 \\
\hline Silt loam & Göttingen $^{c}$ & $\begin{array}{c}1.62 \\
(0.02)\end{array}$ & $\begin{array}{c}0.13 \\
(<0.01)\end{array}$ & n.d. ${ }^{d}$ & 2.05 & 7.38 & 4.18 & 2.32 & 4.9 & 389 \\
\hline
\end{tabular}

${ }^{a}$ Thünen Institute, Braunschweig, Germany

b private agricultural field North of Hannover, water protection area Fuhrberger Feld, Germany

${ }^{\mathrm{c}}$ Reinshof Experimental Farm, Georg-August-University, Göttingen, Germany

${ }^{\mathrm{d}}$ not detectable (i.e. below detection limit of $0.005 \mathrm{mg} \mathrm{L}^{-1} \mathrm{NH}_{4}{ }^{+}-\mathrm{N}$ ) 


\section{$\underline{\text { Soil incubation with selective inhibition }}$}

The experimental design included two factors, (i.) microbial inhibition by fungal and/or bacterial inhibitors and (ii.) activity of $\mathrm{N}_{2} \mathrm{O}$ reductase analyzed either by inhibition with $\mathrm{C}_{2} \mathrm{H}_{2}$ or quantification by ${ }^{15} \mathrm{~N}$ tracing. To address factor (i.), the SIRIN method for determination of the respiratory $\mathrm{F}: \mathrm{B}$ ratio based on $\mathrm{CO}_{2}$ emission was modified to determine $\mathrm{N}_{2} \mathrm{O}$ production by microbial groups. However, in contrast to previous studies by Laughlin and Stevens (2002), McLain and Martens (2006), Blagodatskaya et al. (2010) and Long et al. (2013) we did not pre-incubate the soil with the growth inhibitors, as this could result in changes of the microbial community (e.g. preferential growth of selected organisms). We intended to disturb microbial communities as little as possible.

The soil was sieved ( $2 \mathrm{~mm}$ ) and pre-incubated at $22{ }^{\circ} \mathrm{C}$ for five to seven days in the dark with cotton wool stoppers to allow respiration and aerobic conditions in soil bags. Four microbial inhibitor treatments (each in triplicate) with $\mathrm{c}_{\text {opt }}$ (glucose) for each soil were established:

A Control, without growth inhibitors

B With streptomycin sulfate $\left(\mathrm{C}_{42} \mathrm{H}_{84} \mathrm{~N}_{14} \mathrm{O}_{36} \mathrm{~S}_{3}\right)$ to inhibit bacterial growth

C With cycloheximide $\left(\mathrm{C}_{15} \mathrm{H}_{23} \mathrm{NO}_{4}\right)$ to inhibit fungal growth

D With streptomycin and cycloheximide, to inhibit bacterial and fungal growth

The soil was moistened with distilled water to $80 \%$ water filled pore space (WFPS) and simultaneously fertilized with $\mathrm{NO}_{3}{ }^{-}$(varieties natural and $C_{2} \mathrm{H}_{2}$ with $50 \mathrm{mg} \mathrm{N} \mathrm{kg}{ }^{-1} \mathrm{KNO}_{3}$ in Experiment 1, 2 and 3 and with $60 \mathrm{mg} \mathrm{N} \mathrm{kg}^{-1} \mathrm{NaNO}_{3}$ in Experiment 4 and traced variety with $50 \mathrm{mg} \mathrm{N} \mathrm{kg}{ }^{-1}{ }^{15} \mathrm{~N}_{-} \mathrm{KNO}_{3}$ in Experiment 1, 2 and 3 and 60 mg $\mathrm{N} \mathrm{kg}^{-1}{ }^{15} \mathrm{~N}-\mathrm{KNO}_{3}$ in Experiment 4 with a ${ }^{15} \mathrm{~N}$-labeling of 50 atom\% (at\%)). For each treatment we incubated $100 \mathrm{~g}$ dw soil in $850 \mathrm{~mL}$ preserving jars (J. WECK GmbH u. Co KG, Wehr, Germany) with gas inlet and outlet equipped with three port luer lock stopcocks. A mixture of $\mathrm{c}_{\text {opt }}$ (glucose) and talcum (5 mg talcum $\mathrm{gdw}^{-1}$ ) according to Anderson and Domsch (1978) was added to soil of treatment A and together with the growth inhibitors to the soil of treatments B, C and D. All treatments were mixed for 90 seconds with a handheld electric mixer. The soil density was adjusted to a target soil density of $1.6 \mathrm{~g} \mathrm{~cm}^{-3}$ in Experiment 1,2 and 4 and of $1.3 \mathrm{~g} \mathrm{~cm}^{-3}$ in Experiment 3. To ultimately achieve denitrifying conditions and avoid catalytic NO decomposition in the $\mathrm{C}_{2} \mathrm{H}_{2}$ variety (Nadeem et al., 2013), the headspace of the closed jars was flushed with $\mathrm{N}_{2}$. The manual sample collection of $14 \mathrm{~mL}$ gas in duplicates with a plastic syringe was performed after two, four and eight (Experiment 4) or six, eight and ten hours (Experiment 1, 2 and 3) of incubation time, respectively. The removed gas was replaced by the same amount of $\mathrm{N}_{2}$. 
To address factor (ii.), all microbial inhibitor treatments were conducted in three $\mathrm{N}_{2} \mathrm{O}$ reductase varieties, i.e.: with ${ }^{15} \mathrm{~N}-\mathrm{NO}_{3}$ fertilizer (variety "traced") to quantify $\mathrm{N}_{2} \mathrm{O}$ reduction to $\mathrm{N}_{2}$, with natural abundance $\mathrm{NO}_{3}{ }^{-}$and $10 \mathrm{kPa} \mathrm{C}{ }_{2} \mathrm{H}_{2}$ in the headspace (variety " $\mathrm{C}_{2} \mathrm{H}_{2}$ ") to block $\mathrm{N}_{2} \mathrm{O}$ reductase, and with natural abundance $\mathrm{NO}_{3}{ }^{-}$but without blocking $\mathrm{N}_{2} \mathrm{O}$ reductase, i.e. no $\mathrm{C}_{2} \mathrm{H}_{2}$ added (variety "natural”). In total, we had three soils, three varieties with four treatments each and conducted every treatment with three replicates.

\section{Gas analysis}

Gas samples were analyzed for $\mathrm{N}_{2} \mathrm{O}$ and $\mathrm{CO}_{2}$ concentrations $\left(c\left(\mathrm{~N}_{2} \mathrm{O}\right)\right.$ and $\left.c\left(\mathrm{CO}_{2}\right)\right)$ with a gas chromatograph (GC, Agilent 7890A, Agilent, Böblingen, Germany). The detection limit of $\mathrm{N}_{2} \mathrm{O}$ was $0.04 \mathrm{ng} \mathrm{N} \mathrm{h}^{-1}$ with a measurement precision of $1 \%$ and for $\mathrm{CO}_{2}$ the detection limit was $4 \mathrm{ng} \mathrm{C} \mathrm{h}{ }^{-1}$ with a measurement precision of $0.5 \%$. As a control, $\mathrm{N}_{2}$ and $\mathrm{O}_{2}$ concentrations in the samples were analyzed with GC to ensure anaerobic conditions during the incubation for $\mathrm{N}_{2} \mathrm{O}$ production from denitrification.

The $\mathrm{N}_{2} \mathrm{O}$ isotopologues of the gas samples of varieties natural and $\mathrm{C}_{2} \mathrm{H}_{2}$ were analyzed on a pre-concentrator (PreCon, Thermo-Finnigan, Bremen, Germany) interfaced with a GC (Trace Gas Ultra, Thermo Scientific, Bremen, Germany) and a Delta V isotope ratio mass spectrometer (IRMS, Thermo Fisher Scientific, Bremen, Germany) (Brand, 1995; Köster et al., 2013; Toyoda and Yoshida, 1999). The analytical precision was 0.1 \%o, 0.2 \%o and 1.5 \% for $\delta^{15} \mathrm{~N}_{\text {bulk }}, \delta^{18} \mathrm{O}$ and SP of $\mathrm{N}_{2} \mathrm{O}$, respectively.

The $\mathrm{N}_{2} \mathrm{O}$ samples of variety traced were analyzed for the 29/28 and 30/28 ratios of $\mathrm{N}_{2}$ according to Lewicka-Szczebak et al. (2013) using a modified GasBench II preparation system coupled to a MAT 253 isotope ratio mass spectrometer (Thermo Scientific, Bremen, Germany).

\section{Inhibitor effects}

For interpretation of $\mathrm{N}_{2} \mathrm{O}$ or $\mathrm{CO}_{2}$ production, the validity of the experimental results with respect to fungal and bacterial $\mathrm{N}_{2} \mathrm{O}$ fluxes was checked using a flux balance comparing the sum of bacterial and fungal inhibition effects (treatments B and C) to the dual inhibition effect (treatment D):

$D=A-[(A-B)+(A-C)]$

With $A, B, C$ and $D$ representing the $\mathrm{N}_{2} \mathrm{O}$ production rates of the last sampling time of treatment $A, B, C$ and $D$, respectively. Assuming that in the other three treatments (A, B and 
C) non-inhibitable $\mathrm{N}_{2} \mathrm{O}$ production was equal to treatment $\mathrm{D}, \mathrm{N}_{2} \mathrm{O}$ produced by bacteria or fungi may show the following relation between the four treatments:

$(A-D)=(B-D)+(C-D)$

The fungal fraction contributing on $\mathrm{N}_{2} \mathrm{O}$ production during denitrification with microbial inhibition $\left(F_{F D m i}\right)$ can be calculated, when $\mathrm{N}_{2} \mathrm{O}$ production of treatment $\mathrm{D}$ is significantly lower than $\mathrm{N}_{2} \mathrm{O}$ production of treatments $\mathrm{A}, \mathrm{B}$ and $\mathrm{C}$ by:

$F_{F D m i}=\frac{(A-C)}{(A-D)}$

\section{Isotopomer endmember mixing approach (IEM)}

The fungal fraction $\left(F_{F D}\right)$ contributing to $\mathrm{N}_{2} \mathrm{O}$ production from denitrification in soil samples was calculated according to the isotope mixing model proposed by Ostrom et al. (2010), that was established for calculating the bacterial fraction $\left(\mathrm{F}_{B D}\right)$ on $\mathrm{N}_{2} \mathrm{O}$ production. Assuming that bacteria (OS) and fungi (FD) are the only microorganisms responsible for denitrification in soil, the SP of produced $\mathrm{N}_{2} \mathrm{O}\left(S P_{\text {prod }}\right)$ results from:

$S P_{\text {Prod }}=F_{F D} * S P_{F D}+S P_{O S} * F_{O S}$

where $F_{F D}$ and $F_{O S}$ represent the fraction of $\mathrm{N}_{2} \mathrm{O}$ produced by fungi and other $\mathrm{N}_{2} \mathrm{O}$ sources than fungal denitrification, respectively, and $S P_{F D}$ and $S P_{O S}$ are the respective SP endmember values of $\mathrm{N}_{2} \mathrm{O}$ (Ostrom and Ostrom, 2011; Ostrom et al., 2010). This calculation was based on the assumption that the sum of $F_{O S}$ and $F_{F D}$ equals 1 and that $\mathrm{N}_{2} \mathrm{O}$ reduction to $\mathrm{N}_{2}$ is negligible. Mean $S P_{F D}$ was assumed to be 35 \%o (Rohe et al., 2014a; Sutka et al., 2008) and SP $P_{\text {OS }}$ was assumed to be -11 and 0 \%o (Frame and Casciotti, 2010; Sutka et al., 2006). For this IEM approach, only results from variety $\mathrm{C}_{2} \mathrm{H}_{2}$ could be used, as microorganisms of this variety produce $\mathrm{N}_{2} \mathrm{O}$ that is not affected by reduction to $\mathrm{N}_{2}$.

The opportunity to calculate the fungal fraction (calc. $F_{F D}$ ) contributing to $\mathrm{N}_{2} \mathrm{O}$ production during denitrification was to put the measured SP of $\mathrm{N}_{2} \mathrm{O}$ from treatment A of variety $\mathrm{C}_{2} \mathrm{H}_{2}$ as $S P_{\text {Prod }}$ into Eq. 4. 


\section{$\mathrm{N}_{2} \mathrm{O}$ product ratio $\left(\mathrm{N}_{2} \mathrm{O} /\left(\mathrm{N}_{2}+\mathrm{N}_{2} \mathrm{O}\right)\right)$ of denitrification}

The variety traced served to assess $\mathrm{N}_{2} \mathrm{O}$ reduction during denitrification in each experiment. The $\mathrm{N}_{2} \mathrm{O} /\left(\mathrm{N}_{2}+\mathrm{N}_{2} \mathrm{O}\right)$ product ratio of denitrification as given by the variety traced (product ratio $_{15 N}$ ) was calculated as:

product $_{\text {ratio }}{ }_{15 \mathrm{~N}}=\frac{{ }^{15} \mathrm{~N}-\mathrm{N}_{2} \mathrm{O}}{{ }^{15} \mathrm{~N}-\mathrm{N}_{2}+{ }^{15} \mathrm{~N}-\mathrm{N}_{2} \mathrm{O}}$

with ${ }^{15} \mathrm{~N}-\mathrm{N}_{2} \mathrm{O}$ and ${ }^{15} \mathrm{~N}-\mathrm{N}_{2}$ representing the concentrations of $\mathrm{N}_{2} \mathrm{O}$ and $\mathrm{N}_{2}$ derived from the

${ }^{15} \mathrm{~N}$-labeled fertilizer pool. To check the effectiveness of $\mathrm{C}_{2} \mathrm{H}_{2}$ to block the $\mathrm{N}_{2} \mathrm{O}$ reduction, product ratio $_{15 \mathrm{~N}}$ was compared with product ratio $\mathrm{C}_{2 \mathrm{H} 2}$, where the latter can be calculated from $\mathrm{N}_{2} \mathrm{O}$ production rates of varieties natural and $\mathrm{C}_{2} \mathrm{H}_{2}$ :

product ratio $_{\mathrm{C} 2 \mathrm{H} 2}=\frac{\mathrm{N}_{2} \mathrm{O}_{\text {nat }}}{\mathrm{N}_{2} \mathrm{O}_{\mathrm{C} 2 \mathrm{H} 2}}$

with $\mathrm{N}_{2} \mathrm{O}_{\text {nat }}$ and $\mathrm{N}_{2} \mathrm{O}_{\mathrm{C} 2 \mathrm{H} 2}$ representing the $\mathrm{N}_{2} \mathrm{O}$ produced in varieties natural and $\mathrm{C}_{2} \mathrm{H}_{2}$, respectively.

If product ratio ${ }_{15 \mathrm{~N}}$ and product ratio ${ }_{\mathrm{C} 2 \mathrm{H} 2}$ were in agreement, a complete blockage of $\mathrm{N}_{2} \mathrm{O}$ reduction could be assumed. This enabled to estimate reduction effects on the isotopic signatures of $\mathrm{N}_{2} \mathrm{O}$ by comparing the isotopic values of $\mathrm{N}_{2} \mathrm{O}$ produced without $\mathrm{N}_{2} \mathrm{O}$ reduction effects of variety $\mathrm{C}_{2} \mathrm{H}_{2}$ ( $\delta 0$ values) with isotopic values of $\mathrm{N}_{2} \mathrm{O}$ of variety natural.

\section{Sources of $\mathrm{N}_{2} \mathrm{O}$ produced}

Assuming that denitrification is the only process producing $\mathrm{N}_{2} \mathrm{O}$ in the incubation experiment, the expected ${ }^{15} \mathrm{~N}$ enrichment in $\mathrm{N}_{2} \mathrm{O}$ produced $\left({ }^{15} \mathrm{~N}-\mathrm{N}_{2} \mathrm{Oexp}\right)$ was given by

${ }^{15} N-N_{2} O \exp [a t \%]=\frac{\left(N_{\text {soil }} x{ }^{15} N \text { nat }\right)+\left(N_{\text {fert }} x^{15} N \text { fert }\right)}{N_{\text {bulk }}}$

with $N_{\text {soil }}, N_{\text {fert }}$ and $N_{\text {bulk }}$ describing the amount of $\mathrm{N}$ [mg] in unfertilized soil samples, fertilizer and fertilized soil samples, respectively and ${ }^{15}$ Nnat and ${ }^{15} \mathrm{Nfert}$ is standing for ${ }^{15} \mathrm{~N}$ enrichment under natural conditions (0.3663 at\%) and in fertilizer (50 at\%), respectively. Comparison of measured and expected ${ }^{15} \mathrm{~N}$ enrichment in $\mathrm{N}_{2} \mathrm{O}$ gave information about the contribution of processes other than denitrification contributing on $\mathrm{N}_{2} \mathrm{O}$ production processes.

\section{Statistical Analysis}

We conducted several three-way analyses of variance (ANOVA) to test significant effects of soil, experimental variety and treatment on $\mathrm{N}_{2} \mathrm{O}$ production, $\mathrm{CO}_{2}$ production, and $\mathrm{SP}, \delta^{15} \mathrm{~N}_{\text {bulk }}$ and $\delta^{18} \mathrm{O}$ values of $\mathrm{N}_{2} \mathrm{O}$. The pairwise comparison with Tukey's HSD test was made to find differences between soils, varieties and treatments influencing $\mathrm{N}_{2} \mathrm{O}$ production, $\mathrm{CO}_{2}$ 
production, and SP, $\delta^{15} \mathrm{~N}_{\text {bulk }}$ and $\delta^{18} \mathrm{O}$ values of $\mathrm{N}_{2} \mathrm{O}$. Significant effects of soils and treatments on product ratio ${ }_{\mathrm{C} 2 \mathrm{H} 2}$ and product ratio ${ }_{15 \mathrm{~N}}$ were tested by two-way ANOVA, while differences between soils and treatments influencing the product ratios were tested with pairwise comparison with Tukey's HSD test. Effects of varieties natural and traced on $\mathrm{N}_{2} \mathrm{O}$ and $\mathrm{CO}_{2}$ production were tested by ANOVA. For this ANOVA the $\mathrm{N}_{2} \mathrm{O}$ production rate had to be $\log _{10}$-transformed to achieve homogeneity of variance and normality. The significance level $\alpha$ was 0.1 for every ANOVA. For some ANOVA treatments were excluded, when replicates were $\mathrm{n}<3$. The $\mathrm{N}_{2} \mathrm{O}$ or $\mathrm{CO}_{2}$ production rates of variety $\mathrm{C}_{2} \mathrm{H}_{2}$ were followed over three sampling times by regression. For statistical analysis, we used the program R (R Core Team, 2013).

\section{$\underline{\text { Results }}$}

\section{$\mathrm{N}_{2} \mathrm{O}$ accumulation rates}

$\mathrm{N}_{2} \mathrm{O}$ and $\mathrm{CO}_{2}$ accumulation rates of all treatments were similar in magnitude in almost all cases and mostly indistinguishable (Table 2). $\mathrm{CO}_{2}$ accumulation rates were determined to get additionally information about the denitrifying process. $\mathrm{N}_{2} \mathrm{O}$ accumulation rates exhibited increasing trends with ongoing incubation time for every soil with high variations within the treatments. Contrary to that, $\mathrm{CO}_{2}$ accumulation rates showed decreasing trends (Figure 1, exemplary shown for data of variety $\mathrm{C}_{2} \mathrm{H}_{2}$ ). Calculations of inhibitor effects were based on average $\mathrm{N}_{2} \mathrm{O}$ and $\mathrm{CO}_{2}$ accumulation rates of the entire incubation period, i.e. 8 hours of incubation time for Experiment 1, 2 and 3 and 10 hours for Experiment 4.

$\mathrm{N}_{2} \mathrm{O}$ and $\mathrm{CO}_{2}$ accumulation rates of all treatments with $\mathrm{C}_{2} \mathrm{H}_{2}$ differed significantly among soils $(P<0.001)$ and $\mathrm{N}_{2} \mathrm{O}$ accumulation rates differed as well significantly among treatments $(P<0.001)$. Highest $\mathrm{N}_{2} \mathrm{O}$ production rate about 5.5 to $6.1 \mu \mathrm{g} \mathrm{Ng}^{-1} \mathrm{~h}^{-1}$ was produced in Experiment 1 and 3, while in Experiment 2 and $4 \mathrm{~N}_{2} \mathrm{O}$ production rates were lower after 10 or 8 hours of incubation (2.6 and $2.7 \mu \mathrm{g} \mathrm{N} \mathrm{kg}^{-1} \mathrm{~h}^{-1}$ ), respectively. $\mathrm{N}_{2} \mathrm{O}$ and $\mathrm{CO}_{2}$ accumulation rates were significantly higher in variety $\mathrm{C}_{2} \mathrm{H}_{2}$ than in variety natural of Experiment 1,3 and $4\left(P=0.002, P<0.010\right.$ and $P<0.010$ for $\mathrm{N}_{2} \mathrm{O}$ accumulation rate and $P=0.027, P<0.010$ and $P=0.008$ for $\mathrm{CO}_{2}$ accumulation rate, respectively) (Table 2), while natural and $\mathrm{C}_{2} \mathrm{H}_{2}$ of Experiment 2 did not differ in $\mathrm{N}_{2} \mathrm{O}$ and $\mathrm{CO}_{2}$ accumulation rates $(P=0.402$ and $P=0.288$, respectively). 
Experiment 1

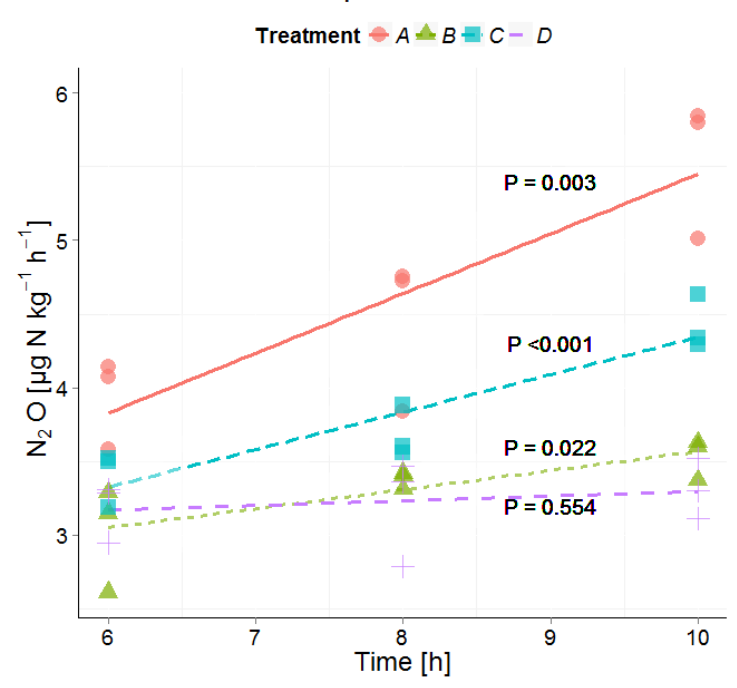

Experiment 2

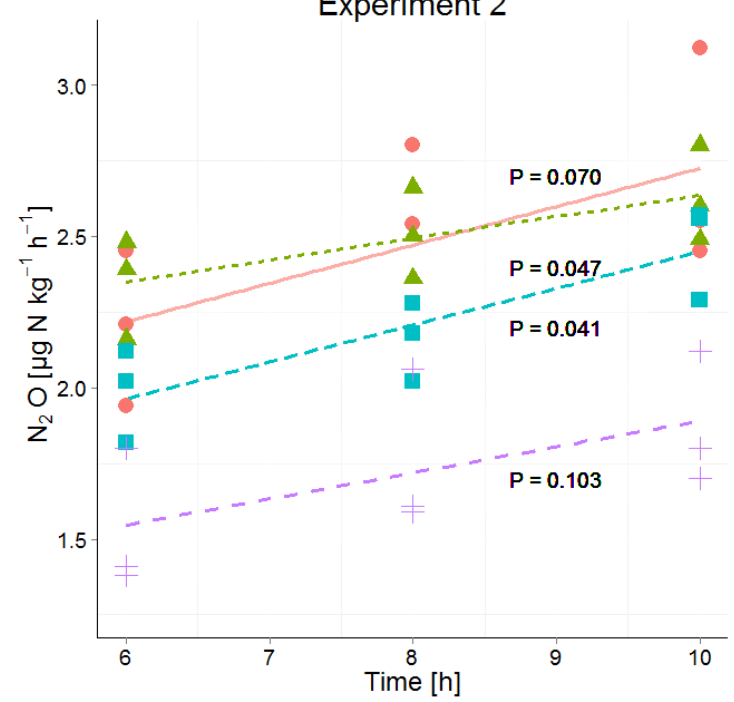

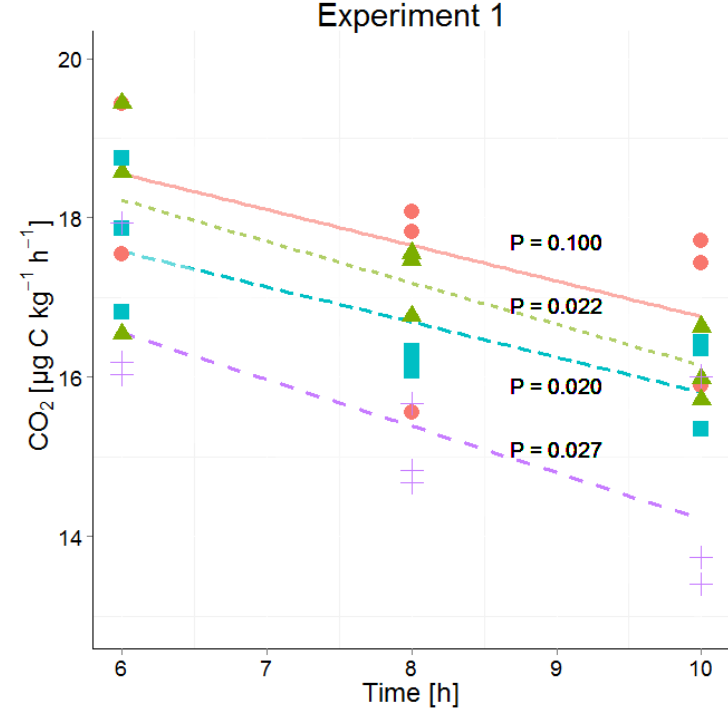

Experiment 2

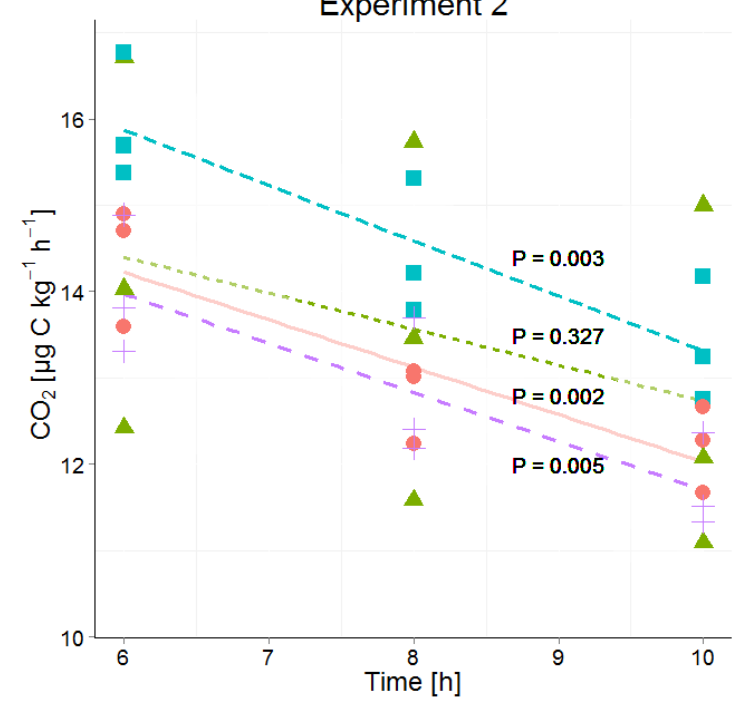

Figure 1: Time series of average $\mathrm{N}_{2} \mathrm{O}$ and $\mathrm{CO}_{2}$ accumulation rates during incubation of variety $\mathrm{C}_{2} \mathrm{H}_{2}$ at the three sample collection times of each soil (Experiment 1 - 4) for treatments A without growth inhibitors, B with bacterial growth inhibition, C with fungal growth inhibition, and D with bacterial and fungal growth inhibition; $P$-values for linear regressions (significance level $\alpha \leq 0.05$ ). For all significant regression $\mathrm{R}^{2}$-values were $\geq 0.46$ and in the case of non-significance $\mathrm{R}^{2}$-values were $\leq 0.40$. n.d.: There was no detectable $\mathrm{N}_{2} \mathrm{O}$ production Experiment 4 at the first sampling time after 2 hours. (Figure is continued on next page) 

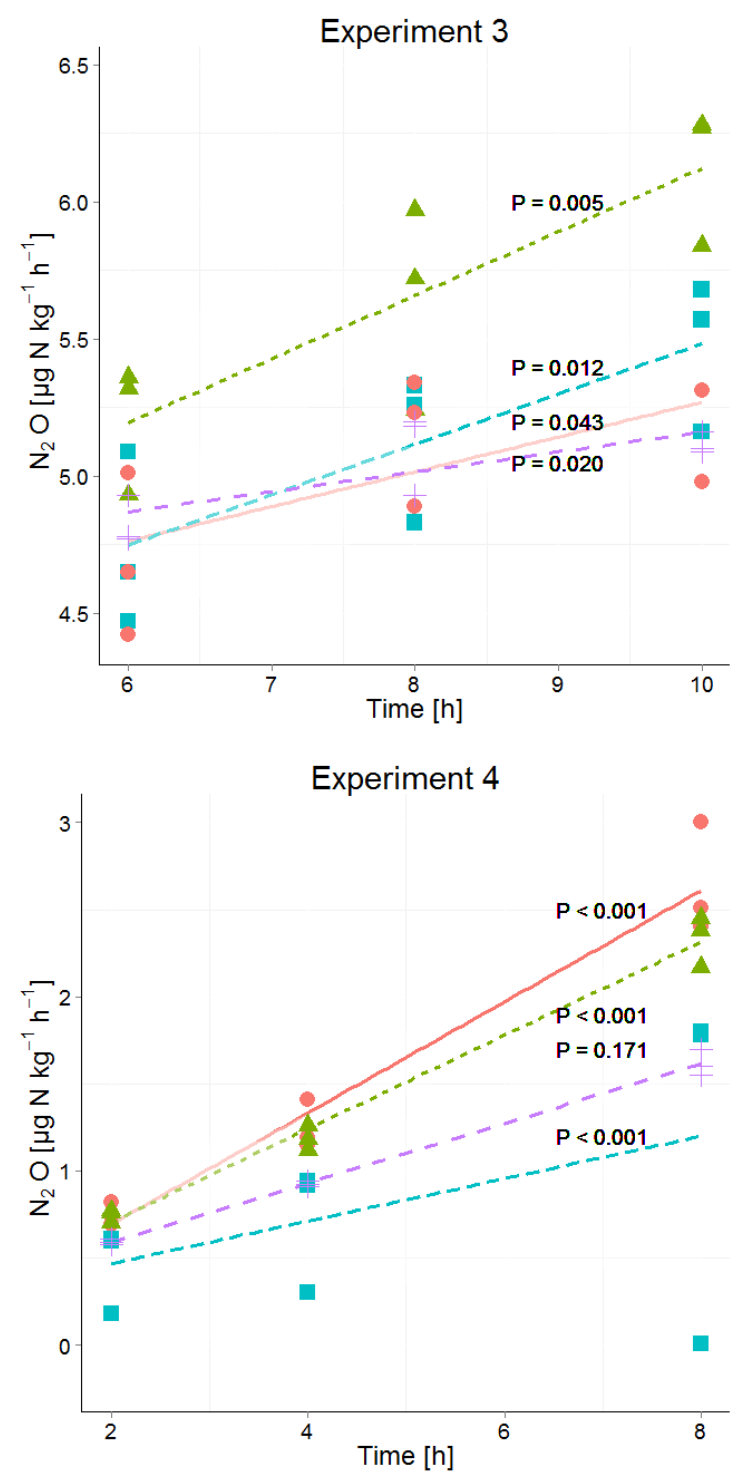

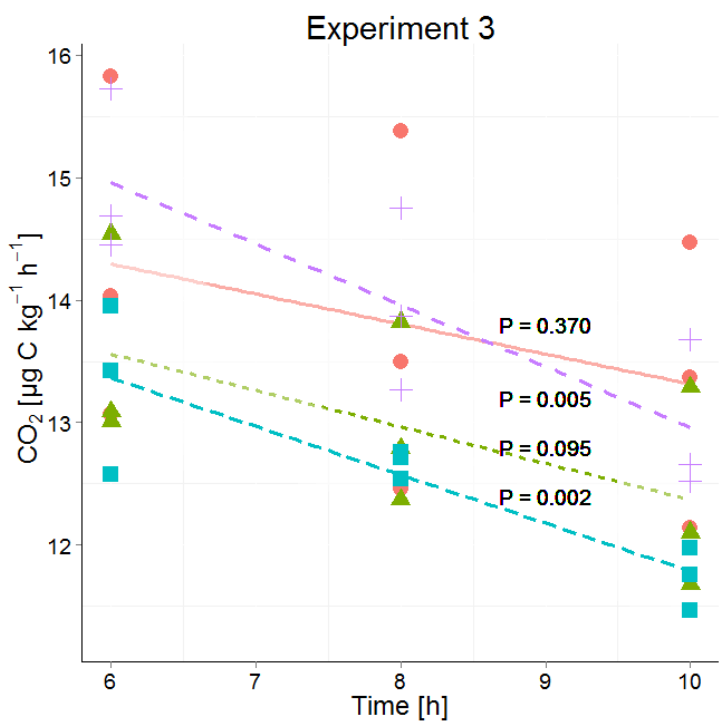

Experiment 4

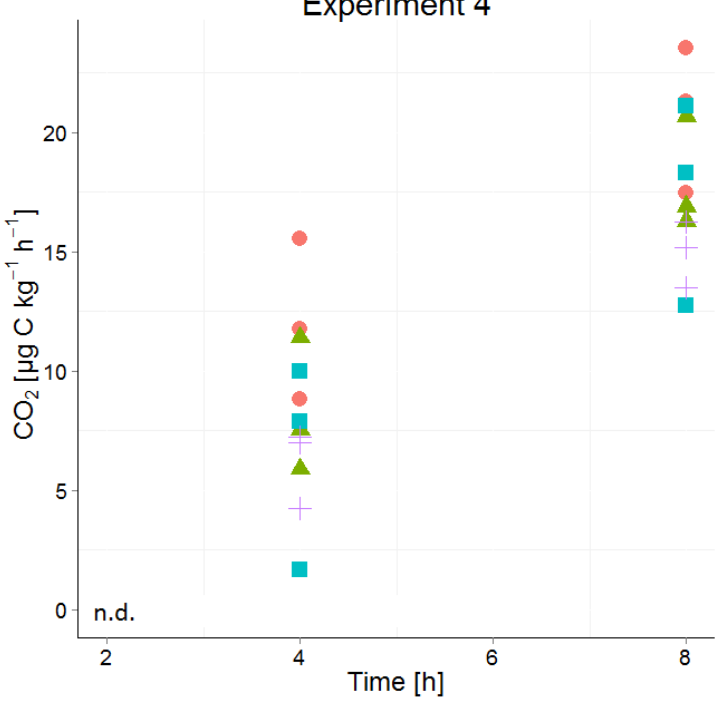

Figure 1 continued.

Without blockage of $\mathrm{N}_{2} \mathrm{O}$ reductase, $\mathrm{N}_{2} \mathrm{O}$ accumulation rates of the treatment A (variety natural) varied significantly among experiments with means between 1.6 and $3.6 \mu \mathrm{g} \mathrm{kg}^{-1} \mathrm{~h}^{-1}(P \leq 0.001)$ (Table 2). In Experiment $1 \mathrm{~N}_{2} \mathrm{O}$ accumulation was significantly higher (2.7 $\left.\mu \mathrm{g} \mathrm{N} \mathrm{kg}^{-1} \mathrm{~h}^{-1}\right)$ compared to Experiment $4\left(1.6 \mu \mathrm{g} \mathrm{N} \mathrm{kg}^{-1} \mathrm{~h}^{-1}\right)(P=0.028)$ in variety natural. The inhibitor application of each variety revealed in most cases that treatment $\mathrm{A}$ (without growth inhibitors) produced most $\mathrm{N}_{2} \mathrm{O}$, followed by either treatment $\mathrm{B}$ (bacterial growth inhibitor; more $\mathrm{N}_{2} \mathrm{O}$ compared to treatment $\mathrm{C}$ in Experiments 2, 3 and 4) or treatments $\mathrm{C}$ (fungal growth inhibitor; more $\mathrm{N}_{2} \mathrm{O}$ compared to treatment $\mathrm{B}$ in Experiment 1). In natural, traced and $\mathrm{C}_{2} \mathrm{H}_{2}$ varieties, non-inhibitable organisms (treatment D) showed lowest $\mathrm{N}_{2} \mathrm{O}$ accumulation rates (except of variety natural of Experiment 1, varieties natural and traced of Experiment 3 and variety traced of Experiment 4). Microbial inhibitor treatments differed significantly in $\mathrm{N}_{2} \mathrm{O}$ accumulation rates within the three $\mathrm{N}_{2} \mathrm{O}$ reductase varieties $\left(\mathrm{C}_{2} \mathrm{H}_{2}\right)$ of 
each experiment (always $P \leq 0.040$ ), with the exception of inhibitor treatments of varieties natural and traced of experiments $4(P=0.154$ and $P=0.154$, respectively). Significant deviations of treatments without (A) or full inhibition (D) were found in the following cases (Table 2): $\mathrm{N}_{2} \mathrm{O}$ accumulation of treatment $\mathrm{A}$ was significantly higher compared to the other three treatments of Experiment $1\left(\mathrm{C}_{2} \mathrm{H}_{2}\right.$ and natural), Experiment $2\left(\mathrm{C}_{2} \mathrm{H}_{2}\right)$ and Experiment 3 $\left(\mathrm{C}_{2} \mathrm{H}_{2}\right)$; treatment D was significantly lower compared to the other three treatments in Experiment 2 (natural) and compared to treatments A and C of Experiment $1\left(\mathrm{C}_{2} \mathrm{H}_{2}\right)$. Comparing variants natural and traced, $\mathrm{N}_{2} \mathrm{O}$ and $\mathrm{CO}_{2}$ accumulation rates did not differ ( $P=0.991$ for $\mathrm{N}_{2} \mathrm{O}$ accumulation rate and $P=0.490$ for $\mathrm{CO}_{2}$ accumulation rate, respectively), confirming that ${ }^{15} \mathrm{~N}$-labeling did not affect $\mathrm{N}_{2} \mathrm{O}$ and $\mathrm{CO}_{2}$ processes. 
Table 2: Average $\mathrm{CO}_{2}$ and $\mathrm{N}_{2} \mathrm{O}$ accumulation rates and $\mathrm{N}_{2} \mathrm{O}$ isotopologue values of $\mathrm{N}_{2} \mathrm{O}$ of the last sample collection with and without $\mathrm{C}_{2} \mathrm{H}_{2}$ application in the headspace (varieties natural and $\mathrm{C}_{2} \mathrm{H}_{2}$ ) of each soil (Experiment 1 - 4) for treatments A without, B with bacterial, C with fungal, and D with bacterial and fungal growth inhibition, respectively (standard deviation in brackets, $n=3$ ).

\begin{tabular}{|c|c|c|c|c|c|}
\hline $\begin{array}{c}\text { Treatment/ } \\
\text { variety }\end{array}$ & $\begin{array}{c}\text { mean } \mathrm{N}_{2} \mathrm{O} \\
{\left[\mu \mathrm{N} \mathrm{kg}^{-1} \mathrm{~h}^{-1} \text { ] }\right.}\end{array}$ & $\begin{array}{c}\text { mean } \mathrm{CO}_{2} \\
{\left[\mu g \mathrm{C} \mathrm{kg}^{-1} \mathrm{~h}^{-1}\right]}\end{array}$ & $\begin{array}{c}\delta^{18} \mathrm{O}-\mathrm{N}_{2} \mathrm{O} \\
{[\% \text { o] }}\end{array}$ & $\begin{array}{c}\delta^{15} \mathrm{~N}_{\text {bulk }}-\mathrm{N}_{2} \mathrm{O} \\
{[\% \text { o] }}\end{array}$ & $\begin{array}{c}{ }^{15} \text { N-SP-N } \\
\text { [\%o] }\end{array}$ \\
\hline \multicolumn{6}{|c|}{ Experiment 1 (Loamy sand, winter 2012) } \\
\hline A natural & $2.7(0.4) \mathrm{a}$ & 12.3 (1.7)a & $13.1(0.2) \mathrm{a}$ & -21.9 (1.7)a & $1.6(0.8) \mathrm{a}$ \\
\hline B natural & $1.8(0.2) \mathrm{b}$ & $12.8(1.6) \mathrm{a}$ & $13.0(<0.1)^{*}$ & $-24.2(0.7)^{*}$ & $-1.3(0.2)^{*}$ \\
\hline C natural & $2.0(0.1) b$ & $11.2(0.5) \mathrm{a}$ & $14.6(0.4) \mathrm{a}$ & $-20.0(0.8) a$ & $-1.6(0.5) \mathrm{a}$ \\
\hline D natural & $2.1(0.3) b$ & $13.7(0.4) \mathrm{a}$ & $15.2(0.5)^{*}$ & $-20.2(1.8)^{*}$ & $-0.3(0.5)^{*}$ \\
\hline $\mathrm{A} \mathrm{C}_{2} \mathrm{H}_{2}$ & $5.5(0.5) \mathrm{a}$ & $17.0(1.0) \mathrm{a}$ & $8.5(0.1) \mathrm{a}$ & $-22.1(0.3) a$ & $-0.4(0.3) \mathrm{a}$ \\
\hline $\mathrm{B} \mathrm{C}_{2} \mathrm{H}_{2}$ & $3.5(0.1) b$ & $16.1(0.5) \mathrm{a}$ & $7.5(0.1) a$ & $-26.1(0.2) \mathrm{a}$ & $-1.2(1.0) \mathrm{b}$ \\
\hline $\mathrm{C} \mathrm{C}_{2} \mathrm{H}_{2}$ & $4.4(0.2) \mathrm{c}$ & $14.0(0.6) \mathrm{a}$ & $9.3(0.2) \mathrm{a}$ & $-22.4(0.4) \mathrm{a}$ & $-0.9(0.4) b$ \\
\hline $\mathrm{D} \mathrm{C}_{2} \mathrm{H}_{2}$ & $3.3(0.2) \mathrm{b}$ & $14.4(1.4) \mathrm{a}$ & $7.8(0.3)^{*}$ & $-24.2(0.1)^{*}$ & $-2.3(0.7)^{*}$ \\
\hline \multicolumn{6}{|c|}{ Experiment 2 (Sand, winter 2012) } \\
\hline A natural & $3.2(0.4) \mathrm{a}$ & 13.1 (1.0)a & 15.5 (1.8)a & $-18.9(2.6) \mathrm{a}$ & $-0.9(2.5) \mathrm{a}$ \\
\hline B natural & $2.4(<0.1) b$ & $12.1(0.2) \mathrm{a}$ & $15.0(1.3) \mathrm{a}$ & $-23.4(2.5) a$ & $-0.8(<0.1) a$ \\
\hline C natural & $2.5(0.2) \mathrm{b}$ & $12.0(0.5) \mathrm{a}$ & $14.3(0.1) \mathrm{a}$ & $-21.8(0.2) \mathrm{a}$ & $-1.8(0.2) \mathrm{a}$ \\
\hline D natural & $2.0(0.3) b$ & $11.0(0.2) \mathrm{a}$ & $13.4(0.3) \mathrm{a}$ & $-24.5(0.1) a$ & $-1.2(0.3) \mathrm{a}$ \\
\hline $\mathrm{A} \mathrm{C}_{2} \mathrm{H}_{2}$ & $2.7(0.4) \mathrm{a}$ & $12.7(2.0) \mathrm{a}$ & $12.6(0.3) \mathrm{a}$ & $-18.9(4.6) a$ & $-1.4(0.3) \mathrm{a}$ \\
\hline $\mathrm{B} \mathrm{C}_{2} \mathrm{H}_{2}$ & $2.6(0.2) \mathrm{a}$ & $13.4(0.7) \mathrm{a}$ & $12.3(0.1) \mathrm{a}$ & $-24.6(0.2) b$ & $-2.0(0.2) \mathrm{a}$ \\
\hline $\mathrm{C} \mathrm{C}_{2} \mathrm{H}_{2}$ & $2.5(0.2) \mathrm{a}$ & $12.2(0.5) \mathrm{a}$ & $12.7(0.1)^{*}$ & $-23.3(0.2)^{*}$ & $-1.7(0.4)^{*}$ \\
\hline $\mathrm{D} \mathrm{C}_{2} \mathrm{H}_{2}$ & $1.9(0.2) \mathrm{b}$ & $11.7(0.6) \mathrm{a}$ & $12.2(0.3) \mathrm{a}$ & $-26.0(0.1) b$ & $-1.5(0.9) a$ \\
\hline \multicolumn{6}{|c|}{ Experiment 3 (Silt loam, winter 2013) } \\
\hline A natural & $3.6(0.2) \mathrm{a}$ & $12.3(1.0) \mathrm{a}$ & $26.0(0.5)$ a & $-20.8(0.5) a$ & $-0.5(0.4) \mathrm{a}$ \\
\hline B natural & $3.3(0.4) \mathrm{a}$ & $11.6(1.8) \mathrm{a}$ & $24.1(0.2) b$ & $-22.0(0.2) b$ & $-0.1(0.4) \mathrm{a}$ \\
\hline C natural & $2.8(0.1) \mathrm{a}$ & $10.6(0.6) \mathrm{a}$ & $27.3(0.1) \mathrm{b}$ & $-20.6(0.3) a$ & $0.6(0.2) \mathrm{a}$ \\
\hline D natural & $2.9(0.4) \mathrm{a}$ & $11.2(0.7) \mathrm{a}$ & $26.3(0.3) \mathrm{a}$ & $-21.0(0.1) \mathrm{a}$ & $-0.04(0.18) \mathrm{a}$ \\
\hline A $\mathrm{C}_{2} \mathrm{H}_{2}$ & $6.1(0.3) \mathrm{a}$ & $13.3(1.2) \mathrm{a}$ & $15.2(0.1) \mathrm{a}$ & $-25.6(0.8) \mathrm{a}$ & $-2.8(0.2) \mathrm{a}$ \\
\hline $\mathrm{B} \mathrm{C}_{2} \mathrm{H}_{2}$ & $5.5(0.3) \mathrm{b}$ & $12.4(0.8) \mathrm{a}$ & $14.9(0.2) \mathrm{a}$ & $-26.3(<0.1) \mathrm{a}$ & $-3.5(0.4) \mathrm{a}$ \\
\hline $\mathrm{C} \mathrm{C}_{2} \mathrm{H}_{2}$ & $5.2(0.2) \mathrm{b}$ & $11.7(0.3) \mathrm{a}$ & $16.2(<0.1)^{*}$ & $-25.2(0.1)^{*}$ & $-4.0(0.4)^{*}$ \\
\hline $\mathrm{D} \mathrm{C}_{2} \mathrm{H}_{2}$ & $5.1(<0.1) b$ & $13.0(0.6) \mathrm{a}$ & $16.0(0.1) b$ & $-25.1(0.1) a$ & $-4.3(0.5) \mathrm{a}$ \\
\hline \multicolumn{6}{|c|}{ Experiment 4 (Loamy sand, summer 2011) } \\
\hline A natural & 1.6 (0.6)a & 24.5 (1.4)a & 25.7 (0.3)a & $-30.6(0.2) \mathrm{a}$ & $12.1(1.6) \mathrm{a}$ \\
\hline B natural & $1.7(0.06) \mathrm{a}$ & $20.9(0.2) b$ & $28.0(5.0) \mathrm{a}$ & $-32.3(0.7) a$ & 7.7 (1.4)b \\
\hline C natural & $1.2(0.03) \mathrm{a}$ & $18.4(1.9) \mathrm{b}$ & $29.3(0.1) \mathrm{a}$ & $-30.0(0.5) a$ & $4.3(1.0) \mathrm{c}$ \\
\hline D natural & $1.2(0.03) \mathrm{a}$ & $16.3(1.2) \mathrm{b}$ & $28.9(1.2) \mathrm{a}$ & $-31.8(2.2) \mathrm{a}$ & $3.4(2.0) \mathrm{c}$ \\
\hline $\mathrm{A} \mathrm{C}_{2} \mathrm{H}_{2}$ & $2.6(0.3) \mathrm{a}$ & 20.8 (3.1)a & $13.5(0.5)^{*}$ & $-34.7(0.1)^{*}$ & $-1.0 * *$ \\
\hline $\mathrm{B} \mathrm{C}_{2} \mathrm{H}_{2}$ & $2.3(0.2) \mathrm{a}$ & 17.9 (2.4)a & 14.3 (1.7)a & $-33.8(0.9) a$ & $-4.9(0.9) a$ \\
\hline $\mathrm{C} \mathrm{C}_{2} \mathrm{H}_{2}$ & $1.2(1.0) \mathrm{a}$ & 17.4 (4.2)a & $19.0(7.0) \mathrm{a}$ & $-33.1(2.8) a$ & $-1.7(2.7) \mathrm{b}$ \\
\hline $\mathrm{D} \mathrm{C}_{2} \mathrm{H}_{2}$ & $1.6(0.1) a$ & $15.0(1.3) \mathrm{a}$ & $14.8(0.5) \mathrm{a}$ & $-35.7(0.2) a$ & $-4.9(0.7) \mathrm{c}$ \\
\hline
\end{tabular}

Lowercase letters (a, b, c, d) denote significant differences $(\mathrm{P}<0.1)$ between groups of treatments of a soil, if one group is significantly different from all other groups.

Asterisk indicate that only two samples $(*)$ or one sample $(* *)$ of triplicates were analyzable. 


\section{Isotopologues of $\mathrm{N}_{2} \mathrm{O}$ produced in different varieties and treatments}

\section{$\underline{\text { Variety } \mathrm{C}_{2} \underline{\mathrm{H}}_{2}}$}

SP of $\mathrm{N}_{2} \mathrm{O}$ of all treatments of variety $\mathrm{C}_{2} \mathrm{H}_{2}$ of all experiments were within a narrow range between -4.9 and $-0.4 \%$ (Table 2), and differed only significantly among treatments of Experiment $4(P=0.002)$. In general there were only small differences between treatments: SP of $\mathrm{N}_{2} \mathrm{O}$ of treatments $\mathrm{A}$ in variety $\mathrm{C}_{2} \mathrm{H}_{2}$ differed significantly $(P<0.001)$ between soils, with highest SP values of $\mathrm{N}_{2} \mathrm{O}$ in Experiment $1\left(-0.4 \%\right.$ ) and lowest SP values of $\mathrm{N}_{2} \mathrm{O}$ in Experiment 3 (-2.8\%o). SP values of treatment D in variety $\mathrm{C}_{2} \mathrm{H}_{2}$ of all soils varied between 1.5 and $-4.9 \%$, but only SP values of Experiment 2 differed significantly from SP values of the other Experiments $(P=0.006)$. For treatments B of variety $\mathrm{C}_{2} \mathrm{H}_{2}$, SP values differed only significantly between Experiment 1 and 4, 2 and 4, 1 and 3 (each $P=0.002$ ). SP of $\mathrm{N}_{2} \mathrm{O}$ from treatment $\mathrm{C}$ in variety $\mathrm{C}_{2} \mathrm{H}_{2}$ did not differ significantly $(P=0.600)$. For every soil we found significantly higher $\delta^{18} \mathrm{O}, \delta^{15} \mathrm{~N}_{\text {bulk }}$ and SP values of $\mathrm{N}_{2} \mathrm{O}$ in variety natural than in variety $\mathrm{C}_{2} \mathrm{H}_{2}(P<0.001)$, except for Experiment 2 , where $\delta^{15} \mathrm{~N}_{\text {bulk }}$ values of $\mathrm{N}_{2} \mathrm{O}$ of variety natural were indistinguishable from variety $\mathrm{C}_{2} \mathrm{H}_{2}(P=0.400)$. However, only in a few varieties there were significant differences in $\delta^{18} \mathrm{O}, \delta^{15} \mathrm{~N}_{\text {bulk }}$ or SP values of $\mathrm{N}_{2} \mathrm{O}$ between treatments with fungal and bacterial inhibition (B and $\mathrm{C}$, respectively) (Table 2). As indicated in the above section, $\mathrm{N}_{2} \mathrm{O}$ reduction blockage in varieties $\mathrm{C}_{2} \mathrm{H}_{2}$ was successful in most cases (Experiment 2, 3 and 4). SP values of $\mathrm{N}_{2} \mathrm{O}$ are thus assumed to be valid estimates of $\delta 0$, i.e. SP of $\mathrm{N}_{2} \mathrm{O}$ production, and can thus be used for applying the IEM.

\section{Variety natural}

SP of $\mathrm{N}_{2} \mathrm{O}$ of all experiments and inhibitor treatments of variety natural were within a range of -1.8 to $12.1 \%$ o (Table 2 ) and did not differ among inhibitor treatments $(P=0.037)$. SP in variety natural of Experiment 4 was particularly high (3.4 to $12.1 \%$ ) compared to the other experiments (1.6 to $-1.6 \%$ ). As already stated above, in variety natural SP of $\mathrm{N}_{2} \mathrm{O}$ was significantly higher than SP of $\mathrm{N}_{2} \mathrm{O}$ in variety $\mathrm{C}_{2} \mathrm{H}_{2}$ (up to $2.4,1.5,4.6$ and $4.1 \%$ in Experiment 1, 2, 3 and 4, respectively).

\section{$\underline{15} \mathrm{~N}$ tracer variety}

The ${ }^{15} \mathrm{~N}$-labeling of $\mathrm{N}_{2} \mathrm{O}\left({ }^{15} \mathrm{~N}-\mathrm{N}_{2} \mathrm{O}\right)$ or $\mathrm{N}_{2}$ produced $\left({ }^{15} \mathrm{~N}-\mathrm{N}_{2}\right)$ gave information about the incorporated $\mathrm{N}$ from ${ }^{15} \mathrm{~N}$-labeled $\mathrm{NO}_{3}{ }^{-}$into $\mathrm{N}_{2} \mathrm{O}$ or $\mathrm{N}_{2}$ as well as $\mathrm{N}_{2} \mathrm{O}$ reduction to $\mathrm{N}_{2}$. Microorganisms in each treatment used the ${ }^{15} \mathrm{~N}$-labeled $\mathrm{NO}_{3}{ }^{-}$in variety traced (Table 3) and 
expected ${ }^{15} \mathrm{~N}-\mathrm{N}_{2} \mathrm{O}$ depended on the initial $\mathrm{N}$ abundance in $\mathrm{NO}_{3}{ }^{-}$of unfertilized soil (Eq. 7). Experiment 4 is the only one showing a large discrepancy between measured (about 30 at\%) and calculated ${ }^{15} \mathrm{~N}-\mathrm{N}_{2} \mathrm{Oexp}$ (49 at\%) in $\mathrm{N}_{2} \mathrm{O}$, whereas the other experiments showed close agreement (Table 3).

\section{Product ratios of denitrification and efficiency of $\mathrm{N}_{2} \mathrm{O}$ reductase blockage by $\mathrm{C}_{2} \mathrm{H}_{2}$}

Product ratio $_{\mathrm{C} 2 \mathrm{H} 2}$ as well as product ratio ${ }_{15 \mathrm{~N}}$ of Experiment 2 were significantly higher than of the other experiments $(P \leq 0.001)$ (Table 3 ). Product ratio ${ }_{15 N}$ of treatment $\mathrm{B}$ was significantly higher than of treatment $C$ and D of Experiment $4(P=0.032)$, while all other treatments of other soils did not differ. Product ratio ${ }_{\mathrm{C} 2 \mathrm{H} 2}$ did not differ significantly between treatments $(P=0.400)$. In order to test the efficiency of blockage of $\mathrm{N}_{2} \mathrm{O}$ reduction by $\mathrm{C}_{2} \mathrm{H}_{2}$ application, product ratio $\mathrm{C} 2 \mathrm{H} 2_{2}$ (Eq. 5) was compared with product ratio ${ }_{15 N}$ (Eq. 6). If varieties $\mathrm{C}_{2} \mathrm{H}_{2}$ were successful in complete blockage of $\mathrm{N}_{2} \mathrm{O}$ reduction both calculated product ratios should result in similar values. In Experiment 1 product ratio ${ }_{\mathrm{C} 2 \mathrm{H} 2}$ was by far smaller than product ratio $_{15 \mathrm{~N}}$, while both calculated product ratios were in similar ranges in the other three experiments and thus a successful blockage of $\mathrm{N}_{2} \mathrm{O}$ reduction was assumed. 
Table 3: Average $\mathrm{CO}_{2}$ and $\mathrm{N}_{2} \mathrm{O}$ accumulation rates of the last sample collection after 10 or 8 hours of variety traced, respectively, with ${ }^{15} \mathrm{~N}$ labeling in $\mathrm{N}_{2} \mathrm{O}\left({ }^{15} \mathrm{~N}-\mathrm{N}_{2} \mathrm{O}\right)$ and the calculated product ratio ${ }_{15 \mathrm{~N}}$ of variety traced and product ratio ${ }_{\mathrm{C} 2 \mathrm{H} 2}$ calculated from $\mathrm{N}_{2} \mathrm{O}$ accumulation rates of variety natural and $\mathrm{C}_{2} \mathrm{H}_{2}$ of each soil (Experiment 1 - 4) for treatments A without, B with bacterial, C with fungal, and D with bacterial and fungal growth inhibition, respectively (standard deviation in brackets, $n=3$ ).

\begin{tabular}{|c|c|c|c|c|c|c|}
\hline Treatment & $\begin{array}{c}\text { mean } \mathrm{N}_{2} \mathrm{O} \\
{\left[\mu \mathrm{N} \mathrm{kg}^{-1} \mathrm{~h}^{-}\right.} \\
\left.{ }_{1}\right]\end{array}$ & $\begin{array}{c}\text { mean } \mathrm{CO}_{2} \\
{\left[\mu g \mathrm{~N} \mathrm{~kg}{ }^{-1} \mathrm{~h}^{-}\right.} \\
\left.{ }_{1}^{*}\right]^{*}\end{array}$ & $\begin{array}{l}{ }^{15} \mathrm{~N}-\mathrm{N}_{2} \mathrm{O} \\
\text { [at\%] }\end{array}$ & $\begin{array}{c}{ }^{15} \mathrm{~N}- \\
\mathrm{N}_{2} \text { Oexp } \\
{[\text { at } \%]^{\mathrm{a}}}\end{array}$ & $\begin{array}{l}\text { Calc. total } \\
\text { product }^{\text {b* }} \\
\text { ratio }_{15 \mathrm{~N}}{ }^{*}\end{array}$ & $\begin{array}{l}\text { Calc. total } \\
\text { product } \\
\text { ratio }_{\mathrm{C} 2 \mathrm{H} 2}{ }^{c^{*}}\end{array}$ \\
\hline \multicolumn{7}{|c|}{ Experiment 1 (Loamy Sand, 2012) } \\
\hline A & $2.6(0.4) \mathrm{a}$ & $13.1(1.7)$ & $36.8(0.1)$ & \multirow{4}{*}{39} & $0.80(0.02)$ & $0.48(0.07)$ \\
\hline B & $1.5(0.3) \mathrm{a}$ & $11.5(2.4)$ & $36.4(0.2)$ & & $0.76(0.02)$ & $0.48(0.05)$ \\
\hline $\mathrm{C}$ & $1.9(1.5) \mathrm{a}$ & $12.2(1.1)$ & $36.9(<0.1)$ & & $0.72(0.05)$ & $0.45(0.04)$ \\
\hline $\mathrm{D}$ & $1.5(0.02) \mathrm{a}$ & $12.5(0.5)$ & $36.8(0.1)$ & & $0.69(0.02)$ & $0.54(0.05)$ \\
\hline \multicolumn{7}{|c|}{ Experiment 2 (Sand, 2012) } \\
\hline A & $2.4(0.01) \mathrm{a}$ & $12.9(0.1)$ & $43.2(<0.1)$ & \multirow{4}{*}{44} & $0.94(0.01)$ & $1.04(0.10)$ \\
\hline B & $1.9(0.03) \mathrm{a}$ & $11.6(0.2)$ & $43.0(0.1)$ & & $0.94(0.01)$ & $0.81(0.04)$ \\
\hline $\mathrm{C}$ & $2.4(0.1) \mathrm{b}$ & $12.8(0.6)$ & $43.2(0.1)$ & & $0.95(0.01)$ & $0.99(0.09)$ \\
\hline $\mathrm{D}$ & $1.7(0.1) \mathrm{a}$ & $12.0(0.3)$ & $42.7(0.1)$ & & $0.93(0.01)$ & $0.98(0.04)$ \\
\hline \multicolumn{7}{|c|}{ Experiment 3 (Silt loam, 2013) } \\
\hline A & $2.9(0.2) \mathrm{a}$ & $10.4(0.5)$ & $35.8(<0.1)$ & \multirow{4}{*}{34} & $0.62(<0.01)$ & $0.52(0.04)$ \\
\hline B & $3.2(0.2) \mathrm{a}$ & $12.0(0.9)$ & $35.5(<0.1)$ & & $0.62(0.01)$ & $0.59(0.02)$ \\
\hline $\mathrm{C}$ & $2.2(0.3) \mathrm{a}$ & $9.8(2.0)$ & $35.5(<0.1)$ & & $0.59(0.02)$ & $0.48(0.04)$ \\
\hline $\mathrm{D}$ & $2.3(0.1) \mathrm{a}$ & $9.9(0.7)$ & $35.3(<0.1)$ & & $0.62(0.01)$ & $0.51(0.04)$ \\
\hline \multicolumn{7}{|c|}{ Experiment 4 (Loamy Sand, 2011) } \\
\hline A & $1.6(0.6) \mathrm{a}$ & $31.1(12.5)$ & $31.1 * * *$ & \multirow{4}{*}{49} & $0.54(0.05)$ & $0.63(0.10)$ \\
\hline B & $1.7(0.06) \mathrm{a}$ & $23.2(3.0)$ & $26.5 * * *$ & & $0.59(0.03)$ & $0.63(0.17)$ \\
\hline $\mathrm{C}$ & $1.2(0.03) \mathrm{a}$ & $17.9(0.8)$ & $30.1^{* *}$ & & $0.50(0.01)$ & $0.62(0.02)$ \\
\hline D & $1.2(0.03) \mathrm{a}$ & $17.1(0.4)$ & $33.5^{* *}$ & & $0.50(0.01)$ & $0.53(0.12)$ \\
\hline
\end{tabular}

Different lowercase letters $(\mathrm{a}, \mathrm{b}, \mathrm{c}, \mathrm{d})$ denote significant $(\mathrm{P}<0.1)$ differences between groups of treatments of a soil if one group is significantly different from all other groups.

Asterisk indicate that only two samples $(* *)$ or one sample (***) was analyzed.

${ }^{\text {a15 }} \mathrm{N}-\mathrm{N}_{2} \mathrm{O} \exp$ [at\%] was calculated from Eq. 7.

broduct ratio ${ }_{15 N}=\mathrm{N}_{2} \mathrm{O} /\left(\mathrm{N}_{2}+\mathrm{N}_{2} \mathrm{O}\right)$ with $\mathrm{N}_{2} \mathrm{O}$ or $\mathrm{N}_{2}$ accumulation rates from variety traced; see Eq. 5 'product ratio ${ }_{\mathrm{C} 2 \mathrm{H} 2}=\mathrm{N}_{2} \mathrm{O}_{\text {nat }} / \mathrm{N}_{2} \mathrm{O}_{\mathrm{C} 2 \mathrm{H} 2}$ with $\mathrm{N}_{2} \mathrm{O}$ accumulation rate from varieties natural and traced; see Eq. 6, cf. Table 2

*No significant differences between treatments of each soil. 


\section{Fungal contribution to $\mathrm{N}_{2} \mathrm{O}$ production from denitrification by microbial inhibitor approach (modified SIRIN)}

When calculating $F_{F D m i}$ contributing to $\mathrm{N}_{2} \mathrm{O}$ production during denitrification $\mathrm{N}_{2} \mathrm{O}$ accumulation rates of treatment $\mathrm{D}$ must be significantly lower compared to the other treatments and the flux balance according to Eq. 1 and 2 must be consistent. This was only the case in Experiment 2 of variety $\mathrm{C}_{2} \mathrm{H}_{2}$. The calculated $F_{F D m i}$ (Eq. 3) contributing to $\mathrm{N}_{2} \mathrm{O}$ production during denitrification was $0.28 \pm 0.09$. The respective flux of fungal $\mathrm{N}_{2} \mathrm{O}$ was $0.24 \pm 0.08 \mu \mathrm{g} \mathrm{N} \mathrm{kg} \mathrm{h}^{-1}$. For all other experiments calculation of $F_{F D m i}$ was not possible.

Fungal contribution to $\mathrm{N}_{2} \mathrm{O}$ production from denitrification by the isotope endmember mixing approach (IEM)

Calculation of the fungal fraction (calc. $F_{F D}$ ) contributing to $\mathrm{N}_{2} \mathrm{O}$ production during denitrification by using Eq. 4 was possible by fitting $F_{F D}$ and $F_{O S}$ to achieve the measured SP values of $\mathrm{N}_{2} \mathrm{O}$ in treatments $\mathrm{A}$ of variety $\mathrm{C}_{2} \mathrm{H}_{2}$ (Table 2). The fitted fungal fraction (calc. $F_{F D}$ ) contributing to $\mathrm{N}_{2} \mathrm{O}$ production did not exceed approximately 0.22 (Table 4).

Table 4: Application of the isotopomer endmember mixing approach (IEM) (Eq. 4) with measured $\mathrm{N}_{2} \mathrm{O}$ accumulation rates and SP of $\mathrm{N}_{2} \mathrm{O}$ produced. Due to the bacterial range of SP values of $\mathrm{N}_{2} \mathrm{O}$ produced the fraction of $\mathrm{N}_{2} \mathrm{O}$ produced by fungi $\left(F_{F D}\right)$ were calculated by Eq. 4 .

\begin{tabular}{lcc}
\hline Experiment & $\begin{array}{c}\text { calc. } \boldsymbol{F}_{\boldsymbol{F D}} \\
\text { ranges }^{\mathbf{a}}\end{array}$ & $\begin{array}{c}\text { calc. } \boldsymbol{F}_{\boldsymbol{F D}} \\
\text { ranges }^{\mathbf{b}}\end{array}$ \\
\hline Experiment 2 & 0 & 0.21 \\
Experiment 3 & 0 & 0.18 \\
Experiment 4 & 0 & 0.22 \\
\hline${ }^{\mathrm{a}}$ Eq. 4 with assuming SP of $\mathrm{N}_{2} \mathrm{O}$ produced by \\
bacteria was $0 \%$ o. \\
bq. 4 with assuming SP of $\mathrm{N}_{2} \mathrm{O}$ produced by \\
bacteria was $-11 \%$.
\end{tabular}

\section{$\mathrm{SP}$ of $\mathrm{N}_{2} \mathrm{O}$ produced by the fungal soil community}

Solving Eq. 4 for $S P_{F D}$ enables to calculate SP of $\mathrm{N}_{2} \mathrm{O}$ produced from the fungal soil community. Estimates for $S P_{F D}$ and $S P_{O S}$ from the results of the modified SIRIN (0.28 and 0.72, respectively, section "Fungal contribution to $\mathrm{N}_{2} \mathrm{O}$ production from denitrification by microbial inhibitor approach (modified SIRIN)“) and $S P_{\text {Prod }}$ of $\mathrm{N}_{2} \mathrm{O}\left(S P_{\text {Prod }}=-1.4 \%\right.$ \%) of the respective treatment $A$ (Table 2) served to calculate SP of $\mathrm{N}_{2} \mathrm{O}$ produced by fungi for Experiment 2. Assuming -11 or 0 \% for the bacterial SP endmember of $\mathrm{N}_{2} \mathrm{O}$ (Frame and Casciotti, 2010; Sutka et al., 2006) resulted in $S P_{F D}$ between $-5 \%\left(S P_{B D}=-11 \%\right)$ and $23 \%$ $\left(S P_{B D}=0 \%\right)$. 


\section{$\underline{\text { Discussion }}$}

This was the first attempt to determine SP of $\mathrm{N}_{2} \mathrm{O}$ produced by fungi or bacteria from soil communities using microbial growth inhibitors with a modification of SIRIN and comparing microbial inhibitor and an isotope endmember mixing (IEM) approaches to estimate fungal contribution to $\mathrm{N}_{2} \mathrm{O}$ production from denitrification. Using IEM revealed that the fungal contribution to $\mathrm{N}_{2} \mathrm{O}$ production was small (calc. $F_{F D} \leq 0.22$ ). One experiment with modified SIRIN allowed the calculation of the fungal fraction producing $\mathrm{N}_{2} \mathrm{O}$ during denitrification and revealed a similar result to the IEM result of about 0.28 . The strict application of the SIRIN method prescribes proof of selectivity of the inhibitors (i.e., streptomycin should not inhibit fungi and cycloheximide should not inhibit bacteria). The results obtained with respect to $\mathrm{N}_{2} \mathrm{O}$ production by the fungal or bacterial fraction were rather unsatisfactory and led to unsolved questions, which are discussed in the following sections.

\section{Experimental setup}

Inhibitor effects, expressed by lower $\mathrm{N}_{2} \mathrm{O}$ production with selective inhibitors (treatments $\mathrm{B}$, $\mathrm{C}$ and $\mathrm{D}$ ) compared to treatments without inhibitors (A), were only minor in the present study. Previous studies found much larger inhibitor effects by pre-incubating the soil with selective inhibitors (Blagodatskaya et al., 2010; Laughlin and Stevens, 2002; Long et al., 2013). The experimental design of our incubation setup was, however, without soil pre-incubation with selective inhibitors, because we aimed to minimize disturbance of soil microbial community and to work with the close to "naturally occurring" F:B ratio. This was contrary to previous studies (Blagodatskaya et al., 2010; Laughlin and Stevens, 2002; Long et al., 2013) and we suppose that pre-incubation with selective inhibitors changes the F:B ratio compared to the undisturbed soil considerably more than soil incubation without this pre-incubation step. Blagodatskaya et al. (2010) did not find more inhibitor efficiency of pre-incubation with streptomycin, but found greater inhibitor effects with pre-incubation with cycloheximide. This could indicate that microbial distribution changed after exposition to this inhibitor. Anderson and Domsch (1975) stated already that $\mathrm{CO}_{2}$ production of initially active organisms can only be ensured up to six or eight hours of experimental duration and biomass activity is changed by both inhibitors (Sutka et al., 2008). It has to be noticed that pre-incubation in the other studies was without glucose, while the $\mathrm{N}_{2} \mathrm{O}$ production was analyzed after the addition of glucose as substrate in previous studies and in the present study as well (Blagodatskaya et al., 2010; Laughlin and Stevens, 2002; Long et al., 2013; McLain and Martens, 2006). Glucose initiates the growth of active organisms. Pre-incubation under denitrifying conditions is not 
needed for microorganisms to produce denitrifying enzymes as pure cultures synthesized enzymes capable of denitrification within two to three hours (USEPA, 1993). We started gas sample collection after two or four hours, when organisms should have produced denitrifying enzymes and microbial growth of initially active organisms should have started. With ongoing incubation time production rates of $\mathrm{CO}_{2}$ decreased, probably because of experimental incubation conditions, for example increasing partial pressure or physiological changes due to staling factors.

The conventional practice of SIRIN implies determination of $\mathrm{c}_{\mathrm{opt}}$ (glucose), $\mathrm{c}_{\mathrm{opt}}$ (streptomycin) or $\mathrm{C}_{\text {opt }}$ (cycloheximide) with a "Ultragas 3" $\mathrm{CO}_{2}$ analyzer (WösthoffCo., Bochum) (Anderson and Domsch, 1973) with continuous gas flow and we used this method to determine optimal concentrations for SIRIN and used these concentrations for the modified SIRIN approach as well. This procedure was also different from studies of other groups (Blagodatskaya et al., 2010; Laughlin and Stevens, 2002; Long et al., 2013), which ascertained optimal concentrations in static systems. We supposed that optimal concentrations for $\mathrm{CO}_{2}$ respiration could work as well for denitrification, if both inhibitors are apt to inhibit the denitrification process as well. SIRIN had been tested with pure cultures and soils for $\mathrm{CO}_{2}$ respiration (Anderson and Domsch, 1975), but information on $\mathrm{N}_{2} \mathrm{O}$ producing processes, especially denitrification, are lacking so far and should be investigated in further studies.

\section{Inhibitor effects}

Even with both growth inhibitors (treatment D) $\mathrm{N}_{2} \mathrm{O}$ production was high in all experiments, i.e., often not significantly lower than the other three treatments. Thus, we suppose similar contributions of non-inhibitable organisms in all other treatments (A, B and C). Noninhibitable organisms could be, for example, bacteria or fungi that are not in growth stage or may be not affected by inhibitors. These organisms could be archaea as well, which are also known to be capable of denitrification (Hayatsu et al., 2008; Philippot et al., 2007). It is known, that archaea are not affected by streptomycin or cycloheximide (Seo and DeLaune, 2010). However, there were some tests to find adequate inhibitors for archaea (halobacteria) (Bonelo et al., 1984) and they found three of 20 antibiotics (erythromycin, chloramphenicol and haloquinone) to inhibit archaeal growth of eleven tested species. However, effects of archaeal occurrence in soil or secondary effects on fungi or bacteria were not tested in this study. 


\section{Is SIRIN without $\mathrm{C}_{2} \mathrm{H}_{2}$ suitable to examine the fungal contribution to $\mathrm{N}_{2} \mathrm{O}$ production in soil?}

In order to determine SP of produced $\mathrm{N}_{2} \mathrm{O}$ without alteration by partial reduction to $\mathrm{N}_{2}, \mathrm{C}_{2} \mathrm{H}_{2}$ was used to block the $\mathrm{N}_{2} \mathrm{O}$ reduction during denitrification quantitatively. We found the expected effect of $\mathrm{C}_{2} \mathrm{H}_{2}$ application, i.e. higher $\mathrm{N}_{2} \mathrm{O}$ production rates in variety $\mathrm{C}_{2} \mathrm{H}_{2}$ compared to variety natural. Calculated product ratios varied between 0.5 and 0.95 (product ratio $_{15 N}$ ) in all soils, showing that $\mathrm{N}_{2} \mathrm{O}$ reduction can have significant effects on measured $\mathrm{N}_{2} \mathrm{O}$ production and isotopic values. The product ratio is controlled by the reaction rate or by the activity of enzymes capable of $\mathrm{N}_{2} \mathrm{O}$ reduction (Nos) in the system. A product ratio of 0.95 (Experiment 2), for example, indicates that nearly 100\% $\mathrm{N}_{2} \mathrm{O}$ from denitrification remains in the system while only minimal amounts of $\mathrm{N}_{2} \mathrm{O}$ are reduced to $\mathrm{N}_{2}$. The calculated product ratio $_{\mathrm{C} 2 \mathrm{H} 2}$ was within the same range as product ratio ${ }_{15 \mathrm{~N}}$ in Experiment 2, 3 and 4 (maximal $9 \%$ difference) which proves the effective blockage of $\mathrm{N}_{2} \mathrm{O}$ reductase in variety $\mathrm{C}_{2} \mathrm{H}_{2}$. Only in Experiment 1 product ratio ${ }_{15 \mathrm{~N}}$ and product ratio ${ }_{\mathrm{C} 2 \mathrm{H} 2}$ differed about $34 \%$ with higher reduction in the tracer variety, which might be explained by potential error sources of the $\mathrm{C}_{2} \mathrm{H}_{2}$ method. Nadeem et al. (2013) found some artifacts with $\mathrm{C}_{2} \mathrm{H}_{2}$, which resulted in lower $\mathrm{N}_{2} \mathrm{O}$ production rates due to $\mathrm{NO}$ oxidation accelerated by $\mathrm{C}_{2} \mathrm{H}_{2}$ application in the presence of very small oxygen $(\mathrm{O})$ amounts $\left(\geq 0.19 \mathrm{~mL} \mathrm{~L}^{-1}\right)$. Moreover incomplete $\mathrm{C}_{2} \mathrm{H}_{2}$ diffusion into denitrifying aggregates might lead to incomplete $\mathrm{N}_{2} \mathrm{O}$ reductase blockage (Groffman et al., 2006). For the other three experiments (2, 3 and 4) it can be supposed that the isotopic signature of $\mathrm{N}_{2} \mathrm{O}$ of variety $\mathrm{C}_{2} \mathrm{H}_{2}$ showed isotopic signatures of produced $\mathrm{N}_{2} \mathrm{O}$ without influences of $\mathrm{N}_{2} \mathrm{O}$ reduction. By comparing varieties natural and $\mathrm{C}_{2} \mathrm{H}_{2}$, isotopologue values of all soils (except $\delta^{15} \mathrm{~N}_{\text {bulk }}$ values of Experiment 2) of variety natural were significantly higher than that of variety $\mathrm{C}_{2} \mathrm{H}_{2}$. The enrichment of residual $\mathrm{N}_{2} \mathrm{O}$ in heavy isotopes is a typical isotope effect associated with $\mathrm{N}_{2} \mathrm{O}$ reduction (Jinuntuya-Nortman et al., 2008; Lewicka-Szczebak et al., 2014; Well and Flessa, 2009). This explains why $\mathrm{C}_{2} \mathrm{H}_{2}$ application is essential for analyzing $\mathrm{N}_{2} \mathrm{O}$ produced by different microbial organism groups from soil.

Due to the lack of $\mathrm{N}_{2} \mathrm{O}$ reductase in most fungi (Shoun et al., 1992), we expected higher product ratios for treatments B with bacterial growth inhibition. However, we did not find significant differences in product ratios within the treatments of one soil and variety. Nevertheless, Experiments 1, 3 and 4 showed the tendency of higher product ratios for treatments $\mathrm{B}$, where probably fungi dominated the microbial community, compared to treatment $\mathrm{C}$, where probably bacteria dominated the microbial community. There was nearly no $\mathrm{N}_{2} \mathrm{O}$ reduction in Experiment 2 independent of the treatment, which might be due to 
microorganisms lacking $\mathrm{N}_{2} \mathrm{O}$ reductase dominating the microbial community or ambient conditions, which lowered the reduction rates.

\section{SP of $\mathrm{N}_{2} \mathrm{O}$ produced by microbial community}

The SP of $\mathrm{N}_{2} \mathrm{O}$ produced of each soil indicated predominantly bacteria to be responsible for $\mathrm{N}_{2} \mathrm{O}$ production from denitrification, providing that results of $\mathrm{SP}$ of $\mathrm{N}_{2} \mathrm{O}$ from denitrification of pure bacterial cultures is transferable to bacteria of soil communities contributing to denitrification. Based on this assumption, there was no evidence of fungi contributing greatly to $\mathrm{N}_{2} \mathrm{O}$ production during denitrification, although the IEM approach revealed a fungal contribution up to $22 \%$ on $\mathrm{N}_{2} \mathrm{O}$ production during denitrification. For all treatments (varieties natural and $\mathrm{C}_{2} \mathrm{H}_{2}$ ) SP of $\mathrm{N}_{2} \mathrm{O}$ was within the range of bacterial dentirification known from pure culture studies to be between -11 and 0 \%o (Frame and Casciotti, 2010; Sutka et al., 2006), with exception of Experiment 4 (variety natural), where $\mathrm{SP}$ of $\mathrm{N}_{2} \mathrm{O}$ of every treatment ( $\mathrm{SP}=3.4$ to $12.1 \%$ ) was in between $\mathrm{SP}$ of $\mathrm{N}_{2} \mathrm{O}$ known from bacterial and fungal dentirification. SP of treatments A differed between soils and this could result from different microbial communities in every soil either with differences in F:B ratios or different species occurring in soils. SP of $\mathrm{N}_{2} \mathrm{O}$ of treatment A within variety $\mathrm{C}_{2} \mathrm{H}_{2}$ showed that the signature of produced $\mathrm{N}_{2} \mathrm{O}$ was not affected by reduction effects and might give evidence of microbial community contributing to $\mathrm{N}_{2} \mathrm{O}$ production regarding differences in SP of $\mathrm{N}_{2} \mathrm{O}$ of pure bacterial or fungal culture studies (Frame and Casciotti, 2010; Rohe et al., 2014a; Sutka et al., 2008; Sutka et al., 2006). However, variations in SP of $\mathrm{N}_{2} \mathrm{O}$ in treatments A of variety $\mathrm{C}_{2} \mathrm{H}_{2}$ are very small and do not give a clear evidence of any differences in microbial soil community producing $\mathrm{N}_{2} \mathrm{O}$. Lewicka-Szczebak et al. (2014) analyzed SP of $\mathrm{N}_{2} \mathrm{O}$ produced during denitrification with blockage of $\mathrm{N}_{2} \mathrm{O}$ reduction by $\mathrm{C}_{2} \mathrm{H}_{2}$ for the same soils as used in the present study for Experiment 1 and 3 and revealed SP values between -3.6 and -2.1 \%o, which is similar to the respective SP values of the present study from -4.9 to $-0.4 \%$. This reinforces the conclusion that bacteria dominate $\mathrm{N}_{2} \mathrm{O}$ production under denitrifying conditions in these both soils. However, there are studies using different soils, which found higher SP values of produced $\mathrm{N}_{2} \mathrm{O}$ unaffected by the reduction of up to +6 \%o (Koester et al., 2013; Lewicka-Szczebak et al., 2014) most probably as a result of higher contributions of fungi on $\mathrm{N}_{2} \mathrm{O}$ production. 


\section{$\delta^{18} \mathrm{O}$ of $\mathrm{N}_{2} \mathrm{O}$}

The analysis of $\delta^{18} \mathrm{O}$ of $\mathrm{N}_{2} \mathrm{O}$ can give information about $\mathrm{O}$ exchange between water and denitrification intermediates by various microorganisms, like it is known for several pure bacterial and fungal cultures (Aerssens et al., 1986; Kool et al., 2007; Rohe et al., 2014b). The range of $\delta^{18} \mathrm{O}$ in our study for variety $\mathrm{C}_{2} \mathrm{H}_{2}$ (7.5 to $19.0 \%$ ) is quite similar to the range found by Lewicka-Szczebak et al. (2014) for the same soils (4.8 to $16.3 \%$ ), where almost complete $\mathrm{O}$ exchange with soil water was documented. Hence, for this study most probably this $\mathrm{O}$ exchange was also very high. Moreover, there were no remarkably differences in $\delta^{18} \mathrm{O}$ values of $\mathrm{N}_{2} \mathrm{O}$ among treatments within one variety and soil and therefore we assume no differences in $\mathrm{O}$ exchange between the treatments.

\section{Codenitrification}

The influence of codenitrification, which is predominantly associated to fungi (Spott et al., 2011), is completely unknown in the present study, but it may have a high impact on $\mathrm{N}_{2} \mathrm{O}$ production, since Laughlin and Stevens (2002) found $\mathrm{N}_{2} \mathrm{O}$ production in their experiment derived to $92 \%$ by codenitrification and only $8 \%$ by denitrification. Until now there is no study focusing on SP of $\mathrm{N}_{2} \mathrm{O}$ produced by codentrification. Codenitrification could have been a co-occuring process in Experiment 4. The ${ }^{15} \mathrm{~N}$ enrichment of soil $\mathrm{NO}_{3}{ }^{-}$was about $60 \%$ higher than analyzed ${ }^{15} \mathrm{~N}$ enrichment in $\mathrm{N}_{2} \mathrm{O}$, leading to the assumption that $\mathrm{N}_{2} \mathrm{O}$ was produced not only by denitrification. When $\mathrm{N}$ in $\mathrm{N}_{2} \mathrm{O}$ originates only from ${ }^{15} \mathrm{~N}$-labeled soil $\mathrm{NO}_{3}{ }^{-}$measured ${ }^{15} \mathrm{~N}$ values of $\mathrm{N}_{2} \mathrm{O}$ should show identical ${ }^{15} \mathrm{~N}$ enrichment to the labeled soil $\mathrm{NO}_{3}{ }^{-}$. During codenitrification, when $\mathrm{N}$ in $\mathrm{N}_{2} \mathrm{O}$ originates from labeled $\mathrm{NO}_{3}{ }^{-}$and also from another unlabeled and unknown $\mathrm{N}$ source, this results in dilution of the applied ${ }^{15} \mathrm{~N}$ labeling of $\mathrm{N}_{2} \mathrm{O}$. In the other soils there was no indication of codenitrification being relevant for $\mathrm{N}_{2} \mathrm{O}$ production. Thus, the SP of $\mathrm{N}_{2} \mathrm{O}$ in Experiment 4 might be influenced by codenitrification. There is no knowledge about the isotopic signature of $\mathrm{N}_{2} \mathrm{O}$ produced during codenitrification so far.

\section{Calculating the fungal fraction contributing to $\mathrm{N}_{2} \mathrm{O}$ production}

Due to the inefficiency of microbial inhibition regarding the $\mathrm{N}_{2} \mathrm{O}$ production in most cases calculation of $F_{F D m i}$ contributing to $\mathrm{N}_{2} \mathrm{O}$ production was only possible for Experiment 2 . Comparing the modified SIRIN with the IEM approach revealed that the fungal fraction contribution to $\mathrm{N}_{2} \mathrm{O}$ production was smaller (0.28 in modified SIRIN and 0.21 in IEM) 
compared to bacterial fraction. Although we did not obtain a very clear picture of various microorganisms contributing to $\mathrm{N}_{2} \mathrm{O}$ production due to the large uncertainties of the calculated fractions, both approaches revealed similar values for the fungal fraction contributing to denitrification.

Since in some soil studies the SP values of $\mathrm{N}_{2} \mathrm{O}$, after correction for the reduction effect on SP, showed significantly higher values (Koester et al., 2013; Lewicka-Szczebak et al., 2014), it can be supposed that based on the IEM approach various soils may largely differ in the microbial community that contributes to $\mathrm{N}_{2} \mathrm{O}$ from denitrification. The three tested soils seemed to contain a microbial community where fungi have minor contribution to $\mathrm{N}_{2} \mathrm{O}$ emissions from denitrification compared to bacteria.

The calculated fungal SP of $\mathrm{N}_{2} \mathrm{O}$ (section " $\mathrm{SP}$ of $\mathrm{N}_{2} \mathrm{O}$ produced by the fungal soil community") from fungal fraction contributing to $\mathrm{N}_{2} \mathrm{O}$ was highly variable (between -5 and $+23 \%$ ) and lower that the SP of $\mathrm{N}_{2} \mathrm{O}$ known from pure cultures (20 - 37 \%) (Rohe et al., 2014a; Sutka et al., 2008) and indicates a high uncertainty of the estimation according to Eq. 4. The IEM should be further investigated with soils, where presumable fungal contribute largely to $\mathrm{N}_{2} \mathrm{O}$ production during denitrification (Koester et al., 2013; Laughlin and Stevens, 2002).

\section{Conclusions}

Although the present study with different selective growth inhibitors did not confirm the expected effect on $\mathrm{N}_{2} \mathrm{O}$ production and SP of $\mathrm{N}_{2} \mathrm{O}$, it can be supposed that fungi played a minor role in $\mathrm{N}_{2} \mathrm{O}$ production from denitrification in the studied soils. The IEM was promising, but was not fully validated, because the fungal fraction contributing to $\mathrm{N}_{2} \mathrm{O}$ production could not be quantified with modified SIRIN. There might be several artefacts in the modified SIRIN, where further studies should focus on, e.g. on effects of bacterial consumption of $\mathrm{N}_{2} \mathrm{O}$ produced by fungi in the presence of bacterial growth inhibitors. The present study could show that consideration of $\mathrm{N}_{2} \mathrm{O}$ reduction in further studies is inevitably necessary. Further studies should also determine the range of SP of $\mathrm{N}_{2} \mathrm{O}$ produced by fungi as well as the effect of specific inhibitors on microbial groups producing $\mathrm{N}_{2} \mathrm{O}$ during denitrification. 


\section{References}

Aerssens, E., Tiedje, J.M., Averill, B.A., 1986. Isotope Labeling Studies on the Mechanisms of N-bond Formation in Denitrification. Journal of Biological Chemistry 261, 96529656.

Anderson, J.P., Domsch, K.H., 1973. Quantification of bacterial and fungal contributions to soil respiration. Archiv Fur Mikrobiologie 93, 113-127.

Anderson, J.P.E., Domsch, K.H., 1975. Measurement of bacterial and fungal contributions to respiration of selected agricultural and forest soil. Canadian Journal of Microbiology 21, 314-322.

Anderson, J.P.E., Domsch, K.H., 1978. Physiological method for quantitative measurement of microbial biomass in soils. Soil Biology \& Biochemistry 10, 215-221.

Blagodatskaya, E., Dannenmann, M., Gasche, R., Butterbach-Bahl, K., 2010. Microclimate and forest management alter fungal-to-bacterial ratio and $\mathrm{N}_{2} \mathrm{O}$-emission during rewetting in the forest floor and mineral soil of mountainous beech forests. Biogeochemistry 97, 55-70.

Blagodatskaya, E.V., Anderson, T.-H., 1998. Interactive effects of $\mathrm{pH}$ and substrate quality on the fungal-to-bacterial ratio and $\mathrm{qCO}_{2}$ of microbial communities in forest soils. Soil Biology and Biochemistry 30, 1269-1274.

Bollag, J.M., Tung, G., 1972. Nitrous oxide release by soil fungi. Soil Biology and Biochemistry 4, 271-276.

Bonelo, G., Ventosa, A., Megás, M., Ruiz-Berraquero, F., 1984. The sensitivity of halobacteria to antibiotics. FEMS Microbiology Letters 21, 341-345.

Braker, G., Conrad, R., 2011. Diversity, Structure, and Size of $\mathrm{N}_{2} \mathrm{O}$-Producing Microbial Communities in Soils-What Matters for Their Functioning?, In: Laskin, A.I., Sariaslani, S., Gadd, G.M. (Eds.), Advances in Applied Microbiology, Vol 75, pp. 3370.

Brand, W.A., 1995. Precon: A Fully Automated Interface for the Pre-GC Cocentration of Trace Gases in Air for Isotopic Analysis. Isotopes in Environmental and Health Studies 31, 277-284.

Bremner, J., 1997. Sources of nitrous oxide in soils. Nutrient Cycling in Agroecosystems 49, 7-16.

Casciotti, K.L., Sigman, D.M., Hastings, M.G., Böhlke, J.K., Hilkert, A., 2002. Measurement of the Oxygen Isotopic Composition of Nitrate in Seawater and Freshwater Using the Denitrifier Method. Analytical Chemistry 74, 4905-4912.

Crenshaw, C.L., Lauber, C., Sinsabaugh, R.L., Stavely, L.K., 2008. Fungal control of nitrous oxide production in semiarid grassland. Biogeochemistry 87, 17-27.

Firestone, M.K., Davidson, E.A., 1989. Microbiological basis of $\mathrm{NO}$ and $\mathrm{N}_{2} \mathrm{O}$ production and consumption in soil, In: Andreae, M.O., Schimel, D.S. (Eds.). Wiley, New York, NY, pp. 7-21.

Frame, C.H., Casciotti, K.L., 2010. Biogeochemical controls and isotopic signatures of nitrous oxide production by a marine ammonia-oxidizing bacterium. Biogeosciences 7, 2695-2709.

Garber, E.A., Hollocher, T.C., 1982. ${ }^{15} \mathrm{~N},{ }^{18} \mathrm{O}$ tracer studies on the activation of nitrite by denitrifying bacteria. Nitrite/water-oxygen exchange and nitrosation reactions as indicators of electrophilic catalysis. Journal of Biological Chemistry 257, 8091-8097.

Groffman, P.M., Altabet, M.A., Bohlke, J.K., Butterbach-Bahl, K., David, M.B., Firestone, M.K., Giblin, A.E., Kana, T.M., Nielsen, L.P., Voytek, M.A., 2006. Methods for measuring denitrification: Diverse approaches to a difficult problem. Ecological Applications 16, 2091-2122. 
Hayatsu, M., Tago, K., Saito, M., 2008. Various players in the nitrogen cycle: Diversity and functions of the microorganisms involved in nitrification and denitrification. Soil Science \& Plant Nutrition 54, 33-45.

IPCC, 2013. Climate Change 2013: The Physical Science Basis. Contribution of Working Group I to the Fifth Assessment Report of the Intergovernmental Panel on Climate Change, In: Stocker, T.F., Qin, D., Plattner, G.-K., Tignor, M., Allen, S.K., Boschung, J., Nauels, A., Xia, Y., Bex, V., Midgley, P.M. (Eds.), Cambridge, United Kingdom and New York, NY, USA, p. 1535 pp.

Jinuntuya-Nortman, M., Sutka, R.L., Ostrom, P.H., Gandhi, H., Ostrom, N.E., 2008. Isotopologue fractionation during microbial reduction of $\mathrm{N}_{2} \mathrm{O}$ within soil mesocosms as a function of water-filled pore space. Soil Biology and Biochemistry 40, 22732280.

Knowles, R., 1982. Denitrification. Microbiological Reviews 46, 43-70.

Koester, J.R., Well, R., Dittert, K., Giesemann, A., Lewicka-Szczebak, D., Muehling, K.-H., Herrmann, A., Lammel, J., Senbayram, M., 2013. Soil denitrification potential and its influence on $\mathrm{N}_{2} \mathrm{O}$ reduction and $\mathrm{N}_{2} \mathrm{O}$ isotopomer ratios. Rapid Communications in Mass Spectrometry 27, 2363-2373.

Kool, D.M., Wrage, N., Oenema, O., Dolfing, J., Van Groenigen, J.W., 2007. Oxygen exchange between (de)nitrification intermediates and $\mathrm{H}_{2} \mathrm{O}$ and its implications for source determination of $\mathrm{NO}_{3}{ }^{-}$and $\mathrm{N}_{2} \mathrm{O}$ : a review. Rapid Communications in Mass Spectrometry 21, 3569-3578.

Köster, J.R., Well, R., Tuzson, B., Bol, R., Dittert, K., Giesemann, A., Emmenegger, L., Manninen, A., Cárdenas, L., Mohn, J., 2013. Novel laser spectroscopic technique for continuous analysis of $\mathrm{N}_{2} \mathrm{O}$ isotopomers - application and intercomparison with isotope ratio mass spectrometry. Rapid Communications in Mass Spectrometry 27, 216-222.

Laughlin, R.J., Stevens, R.J., 2002. Evidence for Fungal Dominance of Denitrification and Codenitrification in a Grassland Soil. Soil Science Society of America Journal 66, $1540-1548$.

Lewicka-Szczebak, D., Well, R., Giesemann, A., Rohe, L., Wolf, U., 2013. An enhanced technique for automated determination of ${ }^{15} \mathrm{~N}$ signatures of $\mathrm{N}_{2},\left(\mathrm{~N}_{2}+\mathrm{N}_{2} \mathrm{O}\right)$ and $\mathrm{N}_{2} \mathrm{O}$ in gas samples. Rapid Communications in Mass Spectrometry 27, 1548-1558.

Lewicka-Szczebak, D., Well, R., Köster, J.R., Fuß, R., Senbayram, M., Dittert, K., Flessa, H., 2014. Experimental determinations of isotopic fractionation factors associated with $\mathrm{N}_{2} \mathrm{O}$ production and reduction during denitrification. Geochimica et Cosmochimica Acta, accepted.

Long, A., Heitman, J., Tobias, C., Philips, R., Song, B., 2013. Co-Occurring Anammox, Denitrification, and Codenitrification in Agricultural Soils. Applied and Environmental Microbiology 79, 168-176.

McLain, J.E.T., Martens, D.A., 2006. $\mathrm{N}_{2} \mathrm{O}$ production by heterotrophic $\mathrm{N}$ transformations in a semiarid soil. Applied Soil Ecology 32, 253-263.

Nadeem, S., Dorsch, P., Bakken, L.R., 2013. Autoxidation and acetylene-accelerated oxidation of NO in a 2-phase system: Implications for the expression of denitrification in ex situ experiments. Soil Biology \& Biochemistry 57, 606-614.

Ostrom, N., Ostrom, P., 2011. The Isotopomers of Nitrous Oxide: Analytical Considerations and Application to Resolution of Microbial Production Pathways, In: Baskaran, M. (Ed.), Handbook of Environmental Isotope Geochemistry. Springer Berlin Heidelberg, pp. 453-476.

Ostrom, N.E., Pitt, A., Sutka, R., Ostrom, P.H., Grandy, A.S., Huizinga, K.M., Robertson, G.P., 2007. Isotopologue effects during $\mathrm{N}_{2} \mathrm{O}$ reduction in soils and in pure cultures of denitrifiers. Journal of Geophysical Research-Biogeosciences 112. 
Ostrom, N.E., Sutka, R., Ostrom, P.H., Grandy, A.S., Huizinga, K.M., Gandhi, H., von Fischer, J.C., Robertson, G.P., 2010. Isotopologue data reveal bacterial denitrification as the primary source of $\mathrm{N}_{2} \mathrm{O}$ during a high flux event following cultivation of a native temperate grassland. Soil Biology and Biochemistry 42, 499-506.

Philippot, L., Hallin, S., Schloter, M., 2007. Ecology of Denitrifying Prokaryotes in Agricultural Soil, In: Donald, L.S. (Ed.), Advances in Agronomy. Academic Press, pp. 249-305.

Popp, B.N., Westley, M.B., Toyoda, S., Miwa, T., Dore, J.E., Yoshida, N., Rust, T.M., Sansone, F.J., Russ, M.E., Ostrom, N.E., Ostrom, P.H., 2002. Nitrogen and oxygen isotopomeric constraints on the origins and sea-to-air flux of $\mathrm{N}_{2} \mathrm{O}$ in the oligotrophic subtropical North Pacific gyre. Global Biogeochemical Cycles 16.

R Core Team, 2013. R: A language and environment for statistical computing. R Foundation for Statistical Computing. R Foundation for Statistical Computing, Vienna, Austria.

Rohe, L., Anderson, T.-H., Braker, G., Flessa, H., Giesemann, A., Lewicka-Szczebak, D., Wrage-Mönnig, N., Well, R., 2014a. Dual isotope and isotopomer signatures of nitrous oxide from fungal denitrification - a pure culture study. Rapid Communications in Mass Spectrometry 28, 1893-1903.

Rohe, L., Anderson, T.-H., Braker, G., Flessa, H., Giesemann, A., Wrage-Mönnig, N., Well, R., 2014b. Fungal oxygen exchange between denitrification intermediates and water. Rapid Communications in Mass Spectrometry 28, 377-384.

Ruzicka, S., Edgerton, D., Norman, M., Hill, T., 2000. The utility of ergosterol as a bioindicator of fungi in temperate soils. Soil Biology and Biochemistry 32, 989-1005.

Seo, D.C., DeLaune, R.D., 2010. Fungal and bacterial mediated denitrification in wetlands: Influence of sediment redox condition. Water Research 44, 2441-2450.

Shoun, H., Kim, D.-H., Uchiyama, H., Sugiyama, J., 1992. Denitrification by fungi. FEMS Microbiology Letters 94, 277-281.

Spott, O., Russow, R., Stange, C.F., 2011. Formation of hybrid $\mathrm{N}_{2} \mathrm{O}$ and hybrid $\mathrm{N}_{2}$ due to codenitrification: First review of a barely considered process of microbially mediated N-nitrosation. Soil Biology \& Biochemistry 43, 1995-2011.

Sutka, R.L., Adams, G.C., Ostrom, N.E., Ostrom, P.H., 2008. Isotopologue fractionation during $\mathrm{N}_{2} \mathrm{O}$ production by fungal denitrification. Rapid Communications in Mass Spectrometry 22, 3989-3996.

Sutka, R.L., Ostrom, N.E., Ostrom, P.H., Breznak, J.A., Gandhi, H., Pitt, A.J., Li, F., 2006. Distinguishing Nitrous Oxide Production from Nitrification and Denitrification on the Basis of Isotopomer Abundances. Applied and Environmental Microbiology 72, 638644.

Tanimoto, T., Hatano, K., Kim, D.H., Uchiyama, H., Shoun, H., 1992. Co-Denitrification by the denitrifying system of fungus Fusarium oxysporum. FEMS Microbiology Letters 93, 177-180.

Toyoda, S., Mutobe, H., Yamagishi, H., Yoshida, N., Tanji, Y., 2005. Fractionation of $\mathrm{N}_{2} \mathrm{O}$ isotopomers during production by denitrifier. Soil Biology and Biochemistry 37, 15351545.

Toyoda, S., Yoshida, N., 1999. Determination of nitrogen isotopomers of nitrous oxide on a modified isotope ratio mass spectrometer. Analytical Chemistry 71, 4711-4718.

USEPA, 1993. Manuel: Nitrogen Control. Office of Water, Washington, D.C. EPA/625/R-93 $/ 010$.

Well, R., Flessa, H., 2009. Isotopologue signatures of $\mathrm{N}_{2} \mathrm{O}$ produced by denitrification in soils. Journal of Geophysical Research: Biogeosciences 114, G02020.

Well, R., Kurganova, I., de Gerenyu, V.L., Flessa, H., 2006. Isotopomer signatures of soilemitted $\mathrm{N}_{2} \mathrm{O}$ under different moisture conditions - A microcosm study with arable loess soil. Soil Biology \& Biochemistry 38, 2923-2933. 
Wrage, N., van Groenigen, J.W., Oenema, O., Baggs, E.M., 2005. A novel dual-isotope labelling method for distinguishing between soil sources of $\mathrm{N}_{2} \mathrm{O}$. Rapid Communications in Mass Spectrometry 19, 3298-3306.

Yoshinari, T., Knowles, R., 1976. Acetylene inhibition of nitrous-oxide reduction by denitrifying bacteria. Biochemical and Biophysical Research Communications 69, 705-710. 


\section{General Discussions}

\section{$\underline{\text { Discussion }}$}

The present study aimed to answer the following questions concerning the fungal pathway of denitrification:

1. Is fungal denitrification associated with an $\mathrm{O}$ exchange between water and denitrification intermediates? What is the characteristic $\mathrm{O}$ isotopic signature of fungally produced $\mathrm{N}_{2} \mathrm{O}$ ?

2. Is the ${ }^{15} \mathrm{~N}$ site preference (SP) of $\mathrm{N}_{2} \mathrm{O}$ produced by fungal pure cultures characterized by higher values compared to SP of $\mathrm{N}_{2} \mathrm{O}$ known from bacterial pure cultures?

3. Are microbial growth inhibitors suitable to quantify the fungal contribution to denitrification in soil and do fungi in soil produce $\mathrm{N}_{2} \mathrm{O}$ with a SP range comparable to $\mathrm{SP}$ of $\mathrm{N}_{2} \mathrm{O}$ from pure cultures?

Two pure culture studies extended the recent knowledge about the isotopic signature of $\mathrm{N}_{2} \mathrm{O}$ produced by fungi. In the ${ }^{18} \mathrm{O}$-traced experiment, the incorporation of ${ }^{18} \mathrm{O}$ from labeled water into $\mathrm{N}_{2} \mathrm{O}$ during denitrification was examined and revealed that fungi, similar to bacteria, showed a significant $\mathrm{O}$ exchange between denitrification intermediates and water. The extent of $\mathrm{O}$ exchange varied among species in a range between $11 \%$ and full exchange. $\mathrm{O}$ exchange differed with regard to the applied electron acceptor. Higher $\mathrm{O}$ exchange rates were observed during denitrification with nitrite compared to nitrate, which indicates the significance of the nitrite reductase in the process of $\mathrm{O}$ exchange and reinforced a hypothesis proposed by Aerssens et al. (1986). Lowest values of O exchange were shown by C. funicola (41\%), the only Sordariales. The other five species under evaluation belonged to the Hypocreales and showed an $\mathrm{O}$ exchange between $74 \%$ and full exchange with nitrite as electron acceptor. Only one ( $F$. solani fsp. pisi) of the six species tested showed higher $\mathrm{O}$ exchange between denitrification intermediates and water with nitrate as electron acceptor than with nitrite. This study proved that the $\mathrm{O}$ isotopic signature of $\mathrm{N}_{2} \mathrm{O}$ cannot be used to differentiate between $\mathrm{N}_{2} \mathrm{O}$ produced by fungal or bacterial denitrification. However, if $\mathrm{O}$ exchange during denitrification in soil might be close to $100 \%$, the isotopic signature of produced $\mathrm{N}_{2} \mathrm{O}$ after complete $\mathrm{O}$ exchange should be stable and well predictable if the $\mathrm{O}$ signature of the ambient water and the isotopic fractionation associated with $\mathrm{O}$ exchange is known.

The SP of $\mathrm{N}_{2} \mathrm{O}$ produced by six fungal species was determined in a natural abundance experiment. A previous study by Sutka et al. (2008) showed very high SP values of produced $\mathrm{N}_{2} \mathrm{O}$ for two of these fungal species ( $\mathrm{SP} \approx 37 \%$ ) and the values found in the current study 
were in the same range. Furthermore, this study supports the assumption that SP values of $\mathrm{N}_{2} \mathrm{O}$ from fungal denitrfiication are higher than those for $\mathrm{N}_{2} \mathrm{O}$ produced by bacterial denitrification (Frame and Casciotti, 2010; Sutka et al., 2006; Toyoda et al., 2005) as the additional four fungal species under evaluation gave SP values between 19.7 and 32.6 \%o. Again only the fungus belonging to the order Sordariales showed deviating results from the other five species belonging to Hypocreales. Besides remarkably small $\mathrm{O}$ exchange during denitrification between denitrifying intermediates and the ambient water, also SP-values of $\mathrm{N}_{2} \mathrm{O}$ produced were by far smaller ( $\mathrm{SP}=19.7 \%$ ) than from the five Hypocreales ( $\mathrm{SP}=30.2$ to $32.6 \%$ ). These results indicate that fungal strains belonging to different genera reveal different isotopic $\mathrm{O}$ exchange between denitrification intermediates and water and SP values of $\mathrm{N}_{2} \mathrm{O}$. This study is the first to report on this phenomenon and indicates that further approaches to analyze the denitrifying process of fungi must take different genera into account. Furthermore, a greater number of fungal species should be considered in future studies, because the six species of the present study only reflect a minimal representation of all fungal species of a soil community.

The performance of comparable experiments with the same six fungal species under denitrifying incubation conditions with an ${ }^{18} \mathrm{O}$ tracer approach on the one hand, and a natural abundance approach on the other hand, enabled the estimation of the extent of $\mathrm{O}$ exchange catalyzed by the different enzymes during denitrification. For this investigation a fractionation model proposed by Snider et al. (2013) for bacterial denitrification was used to estimate enzymes associated with $\mathrm{O}$ exchange. Probably nitrite reductase contributes most to O exchange, whereas nitrate reductase and NO reductase have a minor contribution to the total O exchange of Hypocreales. Again only the Sordariales species showed exceptional results, as most $\mathrm{O}$ exchange was here assumed at NO reductase. This fractionation model gave only initial indications that specific enzymes are predominantly responsible for $\mathrm{O}$ exchange during fungal denitrification. Pure culture studies have to be developed to actually measure the exact extent of $\mathrm{O}$ exchange by single enzymes, e.g. with improved tracer approaches using ${ }^{18} \mathrm{O}$ labeled water and different electron acceptors $\left(\mathrm{NO}_{3}{ }^{-}, \mathrm{NO}_{2}{ }^{-}\right.$or $\left.\mathrm{NO}\right)$ for $\mathrm{N}_{2} \mathrm{O}$ production with various fungal denitrifiers.

The results of the soil studies with selective microbial growth inhibitors indicated that isotopic signatures of $\mathrm{N}_{2} \mathrm{O}$ from denitrification did not show fungal dominance of $\mathrm{N}_{2} \mathrm{O}$ from denitrification in the three tested soils, despite such suggestions by several previous studies (Blagodatskaya et al., 2010; Laughlin and Stevens, 2002; Long et al., 2013; McLain and Martens, 2006). However, the used method of microbial inhibition did not reveal the expected 
effect, i.e. a significant decrease in $\mathrm{N}_{2} \mathrm{O}$ production with the growth inhibition of fungi, bacteria alone or both groups together compared to $\mathrm{N}_{2} \mathrm{O}$ production from the not inhibited soil community. The calculation of reliable values for fungal contribution to $\mathrm{N}_{2} \mathrm{O}$ production from denitrification based on the inhibitor approach was not possible for all soils tested. Simultaneous application of both microbial growth inhibitors, i.e. for fungi and bacteria, resulted only in a small reduction of $\mathrm{N}_{2} \mathrm{O}$ production, indicating that organisms not affected by both antibiotics played an important role. Thus, this not inhibited $\mathrm{N}_{2} \mathrm{O}$ production overlaid the $\mathrm{N}_{2} \mathrm{O}$ production and isotopic fingerprint in treatments with selective growth inhibitors (for fungi or bacteria) as well. As neither knowledge about the microbial composition of this group, nor information of SP values of $\mathrm{N}_{2} \mathrm{O}$ produced, was available, calculating SP of $\mathrm{N}_{2} \mathrm{O}$ produced by the fungal soil community was impossible. However, assuming that bacteria and fungi contributed predominantly to denitrification and that both groups produced SP of $\mathrm{N}_{2} \mathrm{O}$ known from pure culture studies, the isotopic analysis of $\mathrm{N}_{2} \mathrm{O}$ revealed that $\mathrm{N}_{2} \mathrm{O}$ was predominantly produced by bacteria. Different soil types could vary in the composition of microbial communities contributing to $\mathrm{N}_{2} \mathrm{O}$ emissions, which could lead to the discrepancy in findings between the present and previous studies. Hence, further studies should include different soils differing in the microbial community.

The fungal species under evaluation represent only a small portion of fungal species present in soils and five of six species belonged to Hypocreales, while only one species was Sordariales. This again illustrates the insufficient research on fungal denitrification and for this reason, studies focusing on fungal denitrification should be expanded. The present study also revealed the difficulty of transferring knowledge about $\mathrm{N}_{2} \mathrm{O}$ produced by pure cultures to $\mathrm{N}_{2} \mathrm{O}$ produced in soils by either the total microbial community or in soils where either fungal or bacterial growth was inhibited. Future studies should also focus on the effectiveness of microbial inhibitors for denitrification. As bacteria and only a few fungi are known to further reduce $\mathrm{N}_{2} \mathrm{O}$ to $\mathrm{N}_{2}$ during denitrification (Shoun et al., 1992), the measured $\mathrm{N}_{2} \mathrm{O}$ production as well as the isotopic signature of $\mathrm{N}_{2} \mathrm{O}$ may be affected when $\mathrm{N}_{2} \mathrm{O}$ reduction is carried out. The potential bias in estimating fungal $\mathrm{N}_{2} \mathrm{O}$ using selective inhibition, which can be expected due to the lowering of $\mathrm{N}_{2} \mathrm{O}$ reduction when inhibiting bacterial denitrifiers, was confirmed since $\mathrm{SP}$ of $\mathrm{N}_{2} \mathrm{O}$ responded to acetylene, which is used to block $\mathrm{N}_{2} \mathrm{O}$ reduction. This shows that $\mathrm{N}_{2} \mathrm{O}$ reduction has to be taken into account when analyzing the isotopic signature of $\mathrm{N}_{2} \mathrm{O}$ produced from the soil community. In the present study, the expected reduction of $\mathrm{N}_{2} \mathrm{O}$ production after microbial inhibitor application in soil incubation experiments was not 
achieved. Potential interactions between the applied acetylene and the microbial inhibitors, which could affect $\mathrm{N}_{2} \mathrm{O}$ production, have not yet been investigated.

To sum up, the pure culture studies with fungi showed that the isotopic $\mathrm{O}$ signature of $\mathrm{N}_{2} \mathrm{O}$ is not suitable for distinction between fungal or bacterial denitrification, whereas the SP of $\mathrm{N}_{2} \mathrm{O}$ produced by fungi during denitrification might be a promising tool to differentiate between $\mathrm{N}_{2} \mathrm{O}$ produced by bacteria or fungi. Knowledge about the contribution of fungi on $\mathrm{N}_{2} \mathrm{O}$ production during denitrification in soil as well as a validated method to quantify the contributions to $\mathrm{N}_{2} \mathrm{O}$ production from different microbial groups are still lacking. Further studies are necessary to improve the information about the amount of $\mathrm{N}_{2} \mathrm{O}$ produced by fungi to advance models for predicting $\mathrm{N}_{2} \mathrm{O}$ emissions from soil and to find mitigation strategies for $\mathrm{N}_{2} \mathrm{O}$ emissions.

\section{$\underline{\text { References }}$}

Aerssens, E., Tiedje, J.M., Averill, B.A., 1986. Isotope Labeling Studies on the Mechanisms of N-bond Formation in Denitrification. Journal of Biological Chemistry 261, 96529656.

Blagodatskaya, E., Dannenmann, M., Gasche, R., Butterbach-Bahl, K., 2010. Microclimate and forest management alter fungal-to-bacterial ratio and $\mathrm{N}_{2} \mathrm{O}$-emission during rewetting in the forest floor and mineral soil of mountainous beech forests. Biogeochemistry 97, 55-70.

Frame, C.H., Casciotti, K.L., 2010. Biogeochemical controls and isotopic signatures of nitrous oxide production by a marine ammonia-oxidizing bacterium. Biogeosciences 7, 2695-2709.

Laughlin, R.J., Stevens, R.J., 2002. Evidence for Fungal Dominance of Denitrification and Codenitrification in a Grassland Soil. Soil Science Society of America Journal 66, 1540-1548.

Long, A., Heitman, J., Tobias, C., Philips, R., Song, B., 2013. Co-Occurring Anammox, Denitrification, and Codenitrification in Agricultural Soils. Applied and Environmental Microbiology 79, 168-176.

McLain, J.E.T., Martens, D.A., 2006. $\mathrm{N}_{2} \mathrm{O}$ production by heterotrophic $\mathrm{N}$ transformations in a semiarid soil. Applied Soil Ecology 32, 253-263.

Shoun, H., Kim, D.-H., Uchiyama, H., Sugiyama, J., 1992. Denitrification by fungi. FEMS Microbiology Letters 94, 277-281.

Snider, D.M., Venkiteswaran, J.J., Schiff, S.L., Spoelstra, J., 2013. A new mechanistic model of $\delta^{18} \mathrm{O}-\mathrm{N}_{2} \mathrm{O}$ formation by denitrification. Geochimica et Cosmochimica Acta 112, 102-115.

Sutka, R.L., Adams, G.C., Ostrom, N.E., Ostrom, P.H., 2008. Isotopologue fractionation during $\mathrm{N}_{2} \mathrm{O}$ production by fungal denitrification. Rapid Communications in Mass Spectrometry 22, 3989-3996.

Sutka, R.L., Ostrom, N.E., Ostrom, P.H., Breznak, J.A., Gandhi, H., Pitt, A.J., Li, F., 2006. Distinguishing Nitrous Oxide Production from Nitrification and Denitrification on the Basis of Isotopomer Abundances. Applied and Environmental Microbiology 72, 638644. 
Toyoda, S., Mutobe, H., Yamagishi, H., Yoshida, N., Tanji, Y., 2005. Fractionation of $\mathrm{N}_{2} \mathrm{O}$ isotopomers during production by denitrifier. Soil Biology and Biochemistry 37, 1535-1545. 


\section{Summary}

The trace gas nitrous oxide $\left(\mathrm{N}_{2} \mathrm{O}\right)$ contributes to climate change as well as to the depletion of the ozone layer in the stratosphere. Agricultural soils account for about $70 \%$ of the high anthropogenic $\mathrm{N}_{2} \mathrm{O}$ emissions. Microbial processes in soil use, for instance fertilizer $\mathrm{N}$ to produce $\mathrm{N}_{2} \mathrm{O}$, are an important factor. An understanding of $\mathrm{N}_{2} \mathrm{O}$ production pathways is imperative to evaluate reliable mitigation methods for $\mathrm{N}_{2} \mathrm{O}$ emissions.

The present study focused on denitrification, which, besides nitrification and nitrifier denitrification, is one of the main $\mathrm{N}_{2} \mathrm{O}$ production pathways in soils. Denitrification describes the reduction from nitrate $\left(\mathrm{NO}_{3}{ }^{-}\right)$to $\mathrm{N}_{2}$, with nitrite $\left(\mathrm{NO}_{2}{ }^{-}\right)$, nitrous monoxide (NO) and $\mathrm{N}_{2} \mathrm{O}$ as intermediates. For a long time denitrification was attributed only to heterotrophic bacteria. In 1972, however, pure culture studies showed that fungi are also capable of denitrification, and two decades later most fungi were found to lack the $\mathrm{N}_{2} \mathrm{O}$ reductase, resulting in $\mathrm{N}_{2} \mathrm{O}$ being the main product of fungal denitrification instead of $\mathrm{N}_{2}$. This could indicate that fungi might produce more $\mathrm{N}_{2} \mathrm{O}$ compared to bacteria, providing that both groups have the same production rates. However, the contribution of different microbial groups to $\mathrm{N}_{2} \mathrm{O}$ emissions from soil has not yet been sufficiently investigated.

Analysis of the isotopic signature of $\mathrm{N}_{2} \mathrm{O}$ found this to be a promising tool to distinguish between $\mathrm{N}_{2} \mathrm{O}$ produced by different microbial groups. Especially the site preference of ${ }^{15} \mathrm{~N}$ in $\mathrm{N}_{2} \mathrm{O}$ (SP = difference between $\delta^{15} \mathrm{~N}$ of the outer and central $\mathrm{N}$ atoms in $\mathrm{N}_{2} \mathrm{O}$ ) from denitrification revealed differences between pure bacterial cultures ( $\mathrm{SP}=-11$ to $0 \%$ ) and two studied pure fungal cultures (SP 37\%o). Although it is known that all enzymes involved in fungal denitrification, with the exception of the $\mathrm{N}_{2} \mathrm{O}$ reductase, equals the enzymes of bacteria, most denitrification studies with pure cultures covered the bacterial pathway. The different $\mathrm{N}_{2} \mathrm{O}$ reductases might be the reason for different SP of $\mathrm{N}_{2} \mathrm{O}$ produced by bacteria or fungi. An $\mathrm{O}$ exchange between denitrification intermediates and water between 4 and 100\% was found during bacterial denitrification, while there has been no study analyzing the existence of $\mathrm{O}$ exchange during fungal denitrification so far. If $\mathrm{O}$ exchange were not to occur during fungal denitrification, this could provide an additional ability to differentiate between $\mathrm{N}_{2} \mathrm{O}$ produced by fungi or bacteria. The $\mathrm{O}$ isotopic signature of $\mathrm{N}_{2} \mathrm{O}$ produced by fungi would significantly differ from that produced by bacteria.

The present study focused on three subjects. With an isotope tracer experiment with ${ }^{18} \mathrm{O}$ labeled water, the existence of $\mathrm{O}$ exchange between denitrification intermediates and water during denitrification was studied with six fungal species. The fungi showed an $\mathrm{O}$ exchange 
of up to $100 \%$ and consequently a differentiation between fungal and bacterial denitrification with an $\mathrm{O}$ isotopic signature is impossible.

The second subject was verification of the high SP values of $\mathrm{N}_{2} \mathrm{O}$ from fungal denitrification in four additionally tested species and consideration of whether it was reproducible for the two tested species known from literature. This study confirmed higher SP values of $\mathrm{N}_{2} \mathrm{O}$ (SP $=19.7$ to $31.7 \%$ o) compared to the SP of $\mathrm{N}_{2} \mathrm{O}$ known from bacteria. Based on the results of the isotope tracer experiment and the $\mathrm{O}$ isotopic signature of $\mathrm{N}_{2} \mathrm{O}$ under natural conditions, mechanisms of the $\mathrm{O}$ isotope fractionation were analyzed by applying values of fractionation effects known from the literature in an isotope fractionation model to estimate the involved enzymes on $\mathrm{O}$ exchange during denitrification. The $\mathrm{O}$ exchange of $\mathrm{NO}_{2}{ }^{-}$reductase was high compared to $\mathrm{O}$ exchange of $\mathrm{NO}_{3}{ }^{-}$and $\mathrm{NO}$ reductases.

The knowledge obtained from pure fungal culture studies was used in Subject Three to test the transferability to microbial communities in soils by using microbial inhibitors for bacteria or fungi in soil incubation experiments. A modification of substrate induced respiration with selective inhibition (SIRIN) was used to determine whether the specific SP values of $\mathrm{N}_{2} \mathrm{O}$ known for bacteria and fungi are measurable after selective growth inhibition by specific antibiotic application. The expected effect of growth inhibition on SP of $\mathrm{N}_{2} \mathrm{O}$ was not found. In most cases the SP of $\mathrm{N}_{2} \mathrm{O}$ was in the range known from pure bacterial cultures and bacterial growth inhibition did not result in the expected shift of SP values. Consequently the SP values of this incubation experiment did not serve to associate the $\mathrm{N}_{2} \mathrm{O}$ production in inhibited treatments to different microbial groups. It remained unclear if this was due to the modified SIRIN method or if transferability of differences in SP of $\mathrm{N}_{2} \mathrm{O}$ known from fungi and bacteria on a microbial community in soil is possible. Future studies should approach the existing problems regarding the methods to identify fungal denitrification in soil. 


\section{Zusammenfassung}

Das Spurengas Lachgas $\left(\mathrm{N}_{2} \mathrm{O}\right)$ trägt zur Klimaerwärmung und Zerstörung der Ozonschicht in der Atmosphäre bei. Mit einem Anteil von ca. 70\% sind landwirtschaftliche Böden weltweit Hauptverursacher der hohen anthropogenen $\mathrm{N}_{2} \mathrm{O}$ Emissionen. $\mathrm{N}_{2} \mathrm{O}$ entsteht in Böden durch verschiedene mikrobiologische Prozesse, bei denen $\mathrm{N}_{2} \mathrm{O}$ unter anderem aus düngerbürtigem N gebildet wird. Die Entwicklung effektiver Minderungsmaßnahmen wird erst möglich, wenn ein Verständnis der $\mathrm{N}_{2} \mathrm{O}$ Quellprozesse und ihrer Dynamik in Böden vorhanden ist.

In dieser Studie wurde die Denitrifikation als ein Quellprozess untersucht, der zusammen mit Nitrifikation und Nitrifizierer-Denitrifikation hauptsächlich für die $\mathrm{N}_{2} \mathrm{O}$ Emissionen aus Böden verantwortlich ist. Die Denitrifikation beschreibt die Reduktion von Nitrat $\left(\mathrm{NO}_{3}{ }^{-}\right) \mathrm{zu}$ $\mathrm{N}_{2}$, wobei Nitrit $\left(\mathrm{NO}_{2}{ }^{-}\right.$), Stickstoffmonoxid (NO) und $\mathrm{N}_{2} \mathrm{O}$ Zwischenprodukte dieses Reaktionsweges sind. Lange Zeit galten heterotrophe Bakterien als alleinige Verursacher von $\mathrm{N}_{2} \mathrm{O}$ Emissionen aus der Denitrifikation. Im Jahr 1972 wurde allerdings in Versuchen mit Pilzreinkulturen nachgewiesen, dass auch Pilze in der Lage sind, $\mathrm{N}_{2} \mathrm{O}$ über die Denitrifikation zu bilden. Zwei Jahrzehnte später wurde gezeigt, dass den meisten Pilzen das Enzym $\mathrm{N}_{2} \mathrm{O}-$ Reduktase fehlt. Somit ist nicht $\mathrm{N}_{2}$, sondern $\mathrm{N}_{2} \mathrm{O}$ das hauptsächliche Endprodukt der pilzlichen Denitrifikation. Dies lässt vermuten, dass die Bildung von $\mathrm{N}_{2} \mathrm{O}$ durch pilzliche Denitrifikation noch unterschätzt wird, vorausgesetzt Pilze und Bakterien haben ähnliche Prozessraten. Bisher wurde jedoch nicht ausgiebig erforscht, welchen Anteil die einzelnen mikrobiellen Gemeinschaften an der $\mathrm{N}_{2} \mathrm{O}$ Bildung tatsächlich haben.

Zur Unterscheidung der $\mathrm{N}_{2} \mathrm{O}$ Bildungsprozesse in Bezug auf die beteiligten Mikroorganismen stellt die Isotopenanalyse von $\mathrm{N}_{2} \mathrm{O}$ eine vielversprechende Anwendung dar. Vor allem die ${ }^{15} \mathrm{~N}$-Positionspräferenz im $\mathrm{N}_{2} \mathrm{O}$ (SP = site preference, d.h. die Differenz zwischen den $\delta^{15} \mathrm{~N}$-Werten der außenständigen und zentralen N-Atome im linearen $\mathrm{N}_{2} \mathrm{O}$-Molekül) aus der Denitrifikation zeigte starke Unterschiede zwischen Reinkulturen einiger Bakterien (SP = -11 bis $0 \%$ ) und zwei untersuchten Pilzen (SP 37\%o). Jedoch wurden Bakterienreinkulturen bisher ausgiebiger untersucht als Pilzreinkulturen, auch wenn bekannt ist, dass sich die beteiligten Enzyme bei der Denitrifikation, bis auf die NO-Reduktase, zwischen Bakterien und Pilzen nicht unterscheiden. Die verschiedenen NO-Reduktasen sind vermutlich die Ursache für die unterschiedlichen SP-Werte des von Pilzen und Bakterien produzierten $\mathrm{N}_{2} \mathrm{O}$. Des Weiteren wurde bei Bakterien ein Austausch der Sauerstoffatome von Zwischenprodukten der Denitrifikation und dem umgebenden Wasser gefunden, der zwischen 4 und $100 \%$ beträgt. Ob es einen solchen Sauerstoffaustausch auch bei Pilzen gibt, ist bisher jedoch unerforscht. Würde der Sauerstoffaustausch bei pilzlicher Denitrifikation nicht 
erfolgen, ermöglichte dies neben der unterschiedlichen SP eine weitere Unterscheidung der Herkunft des $\mathrm{N}_{2} \mathrm{O}$. Der Sauerstoffaustausch würde signifikante Unterschiede in der $\mathrm{O}$ Isotopensignatur im $\mathrm{N}_{2} \mathrm{O}$ pilzlicher bzw. bakterieller Herkunft verursachen.

In der vorliegenden Studie, die Aufschluss über die pilzliche $\mathrm{N}_{2} \mathrm{O}$ Produktion aus der Denitrifikation geben soll, wurden drei Hauptthemen behandelt. In einem IsotopenTracerexperiment mit ${ }^{18} \mathrm{O}$-angereichertem Wasser wurde untersucht, ob bei sechs Pilzreinkulturen ein Sauerstoffaustausch zwischen Wasser und Zwischenprodukten der Denitrifikation stattfindet. Die Pilzreinkulturen zeigten tatsächlich durch Inkorporation von ${ }^{18} \mathrm{O}$ aus Wasser in $\mathrm{N}_{2} \mathrm{O}$ einen Sauerstoffaustausch. Auch Pilze können bis zu $100 \%$ des $\mathrm{O}$ während der Denitrifikation austauschen. Eine Unterscheidung zwischen der Denitrifikation durch Bakterien und Pilze anhand der Sauerstoffsignatur ist somit nicht möglich.

Das zweite Thema sollte Auskunft darüber geben, ob hohe SP-Werte des $\mathrm{N}_{2} \mathrm{O}$ aus der Denitrifikation bei Pilzreinkulturen allgemeingültig sind. Neben den zwei bisher untersuchten wurden vier weitere Pilzreinkulturen inkubiert. Diese Studie zeigte für die getesteten Pilzarten ebenfalls höhere SP-Werte ( $\mathrm{SP}=19.7$ bis 32.6\%) im Vergleich zum Wertebereich von Bakterienreinkulturen. Basierend auf den Ergebnissen zum Sauerstoffaustausch aus dem Isotopen-Tracerexperiment wurde für die jeweiligen sechs Pilze, anhand der im Rahmen dieses Versuchs ermittelten natürlichen Sauerstoffisotopensignaturen, Mechanismen zur O Isotopenfraktionierung untersucht. Dafür wurden, neben den Werten des Sauerstoffaustausches und der natürlichen O Isotopensignatur der Pilzreinkulturen, Werte für Fraktionierungseffekte aus der Literatur in einem Isotopenfraktionierungsmodell angewendet, um die Beteiligung der verschiedenen Enzyme, die während der Denitrifikation an dem Sauerstoffaustausch beteiligt sind, abzuschätzen. Im Vergleich zu den $\mathrm{NO}_{3}^{-}-$und $\mathrm{NO}-$ Reduktasen wies die $\mathrm{NO}_{2}{ }^{-}$-Reduktase einen maßgeblich höheren Sauerstoffaustausch auf. Die Erkenntnisse aus den Experimenten mit den Pilzereinkulturen sollten im Rahmen des dritten Themas auf Ihre Übertragbarkeit auf die mikrobiellen Gemeinschaften in Böden untersucht werden, indem Bodeninkubationsversuche mit selektiver Hemmung der Organismengruppen (Pilze und Bakterien) durchgeführt wurden. Bei dieser Modifizierung der Methode zur Substrat-induzierten Respiration mit selektiver Hemmung (SIRIN) sollte untersucht werden, ob sich die spezifischen SP-Werte für Bakterien und Pilze nach selektiver Wachstumshemmung von Bodengemeinschaften durch spezifische Antibiotika nachweisen lassen. Die Ausprägung des Hemmungseffekts auf SP-Werte in den drei getesteten Böden entsprach nicht den Erwartungswerten, die sich aus den SP-Werten der Pilz- und Bakterienreinkulturen ergaben. Die ermittelten SP-Werte lagen in den meisten Fällen im 
Bereich jener bakterieller Reinkulturen und eine Hemmung der Bakterien führte in keinem Fall zu der erwarteten Veränderungen der SP-Werte. Folglich konnten die SP-Werte dieser Versuche nicht dazu dienen, die $\mathrm{N}_{2} \mathrm{O}$ Bildung in den gehemmten Varianten den verschiedenen Organismengruppen zu zuordnen. Ungeklärt blieb, ob dies durch fehlende Eignung der modifizierten SIRIN-Methode zu erklären ist, oder ob die an Reinkulturen beobachteten SP-Unterschiede zwischen Pilzen und Bakterien nicht auf mikrobielle Gemeinschaften der Versuchsböden übertragbar sind. Im Hinblick auf nach wie vor bestehende methodische Defizite bei der Untersuchung der Pilzdenitrifikation im Boden sollte dies in weitergehenden Studien geklärt werden. 


\title{
Curriculum Vitae
}

\author{
Name: $\quad$ Lena Rohe \\ Date of Birth: $\quad$ September $3^{\text {rd }}, 1984$ in Haselünne, Germany
Position: $\quad$ PhD student
Address: $\quad$ Thünen-Institute of Climate-Smart Agriculture
Bundesallee 50,
38116 Braunschweig - Germany \\ Phone: $\quad+495315962655$ \\ E-Mail: $\quad$ lena.rohe@ti.bund.de
}

Education:

2004 Abitur at the Ubbo-Emmius-Gymnasium in Leer

$2004-2009 \quad$ Study of Geoecology at the Technical University of Braunschweig

2009 Diploma of Geoecology, thesis title: ,,Temperaturreaktionen von Asellus aquaticus (L.)“

2010 - dato $\quad$ PhD student at the Institute of Grassland Science, University of Göttingen within the project "Real time monitoring of N-species isotopologues by FTIR spectroscopy - A novel tool to investigate shortterm isotopic dynamics and $\mathrm{N}_{2} \mathrm{O}$ formation in soil” (2010 - 2013), which was financially supported by the State of Lower-Saxony and the Volkswagen Foundation, Hannover, Germany;

Working guest scientist at Thünen-Institute for Climate-Smart Agriculture 


\section{List of publications}

2010

- KTBL conference, Bad Staffelstein, Germany (2010) (Emissionen landwirtschaftlich genutzter Böden): Anteil der pilzlichen und bakteriellen $\mathrm{N}_{2} \mathrm{O}$-Bildung in verschiedenen Böden -Konzept und Versuchsdesign- (poster presentation)

2011

- Annual Meeting of German Society of Soil Science (2011): Anteil von Pilzen und Bakterien an der $\mathrm{N}_{2} \mathrm{O}$-Bildung in verschiedenen Böden (oral presentation)

- Rohe, L., Well, R., Wrage, N., Anderson, T.-H-, Flessa, H. (2011). Anteil von Pilzen und Bakterien an der Lachgasbildung in verschiedenen Böden, Annual Meeting of German Society of Soil Science, non-peer-reviewed online-publication

- Nitrogen Workshop, Wexford, Ireland (2012): Differentiation between fungi and bacteria as a source of $\mathrm{N}_{2} \mathrm{O}$ formation in soil (poster presentation)

- 8th Isoecol, Brest, France (2012): Using site preference of $\mathrm{N}_{2} \mathrm{O}$ to differentiate between fungal and bacterial $\mathrm{N}_{2} \mathrm{O}$ formation in soil (poster presentation)

- Jesium, Leipzig, Germany (2012): Isotopomer ratios of $\mathrm{N}_{2} \mathrm{O}$ produced during denitrification by fungal pure cultures and associated oxygen exchange with water (poster presentation)

- 17th Nitrogen Cycle Meeting, Oslo, Norway (2012): Isotopomer ratios of $\mathrm{N}_{2} \mathrm{O}$ produced during denitrification by fungal pure cultures and associated oxygen exchange with water (poster presentation)

2013

- Lewicka-Szczebak, D., Well, R., Giesemann, A., Rohe, L., Wolf, U. (2013): An enhanced technique for automated determination of ${ }^{15} \mathrm{~N}$ signatures of $\mathrm{N}_{2},\left(\mathrm{~N}_{2}+\mathrm{N}_{2} \mathrm{O}\right)$ and $\mathrm{N}_{2} \mathrm{O}$ in gas samples, Rapid Communications in Mass Spectrometry 27, 15481558 .

- General assembly of European Geoscience Union, Vienna, Austria (2013): Isotope Effects and $\mathrm{O}$ Exchange with water during $\mathrm{N}_{2} \mathrm{O}$ Production by Denitrifying Fungi (poster presentation)

- COST-SIBAE Meeting, Wroclaw, Poland (2013): Selective inhibition and Isotopomer Analysis of $\mathrm{N}_{2} \mathrm{O}$ to Estimate the $\mathrm{N}_{2} \mathrm{O}$ Formation by Fungal Denitrification in Soil (poster presentation)

- First Conference of Scientific Cooperation between Lower Saxony and Israel (2013): Isotopomer analysis of $\mathrm{N}_{2} \mathrm{O}$ after selective inhibition to estimate fungal $\mathrm{N}_{2} \mathrm{O}$ fomation during denitrification in soil (poster presentation)

- ASI-Jahrestagung (2013): Selective inhibition and isotopomer analysis of $\mathrm{N}_{2} \mathrm{O}$ to estimate the $\mathrm{N}_{2} \mathrm{O}$ formation by fungal denitrification in soil (poster presetation)

2014

- Rohe, L., Anderson, T.-H., Braker, B., Flessa, H., Giesemann, A., Wrage-Mönnig, N., Well, R., 2014. Fungal Oxygen Exchange between Denitrification Intermediates and Water. Rapid Communications in Mass Spectrometry 28, 377-384. 


\section{Danksagung}

Das Promotionsprojekt war Teil des Projektes „Pathways of $\mathrm{N}_{2} \mathrm{O}$ with special emphasis on the distinction between fungal and bacterial denitrification as affected by soil type, land use and water-content -quantification of N-rates and associated isotope effects", das vom Land Niedersachsen und der VolkswagenStiftung finanziert wurde.

Als erstes möchte ich Prof. Dr. Nicole Wrage-Mönnig und Dr. Reinhard Well für die Betreuung des Projektes danken. Herzlichen Dank für eure Unterstützung, ohne die die Bearbeitung des Projektes nicht möglich gewesen wäre. Eure Hilfestellung und Erfahrung bei der Umsetzung der Projektziele hat mich immer wieder vorangetrieben. Vielen Dank auch für die Motivation, die ich aus Gesprächen mit Euch schöpfen konnte. Obwohl die Zeit im Arbeitsalltag meist knapp war, habt ihr euch immer Zeit genommen für meine Fragen oder Probleme. Vielen Dank!

Prof. Dr. Johannes Isselstein und Sabine Hippe danke ich für die freundliche Aufnahme in der Abteilung Graslandwissenschaften des DNPW der Universität Göttingen.

Ich freue mich, dass ich auch in einem zweiten Team so herzlichen aufgenommen wurde und bedanke mich daher beim Thünen-Institut für Agrarklimaschutz, besonders bei Prof. Dr. Heinz Flessa, für die Möglichkeit meine Doktorarbeit dort schreiben zu können.

Ein besonderer Dank gilt Frau Dr. Anderson für viele hilfreiche und unterstützende Gespräche über das Durchführen von Versuchen und Verfassen von Manuskripten. Ihre Erfahrung, die sie in die Bearbeitung einfließen lassen haben und ihre motivierenden Worte haben mir sehr geholfen.

Dr. Anette Giesemann danke ich für den einwöchigen Crashkurs zur Messung am Massenspektrometer und auch für zahlreiche Diskussionen über Probenmessungen, Ergebnisse und den Interpretationsmöglichkeiten!

Dr. Dominika Lewicka-Szczebak danke ich für viele Ideen zu Versuchsdurchführungen und viele anregende Diskussionen!

Natürlich wäre all die Arbeit ohne das tolle Laborteam nicht möglich gewesen. Daher danke ich dem technischen Personal für die Unterstützung im Labor, besonders Susanne Behn und Martina Heuer!

Bei Marianna Deppe, Greta Roth, Ulrike Wolf, Jasmin Miltz und Caroline Buchen bedanke ich mich für viele aufmunternde Gespräche und auch für viele Hilfestellungen. 
Während meiner Doktorarbeit hatte ich zwei tolle Laboraufenthalte. Ich bedanke mich herzlich für eure Hilfe und die Einführung in die Arbeit mit Bakterien und Pilzen. Durch die beiden Laboraufenthalte konnte ich die Methoden, die ich bei den Versuchen angewendet habe erlernen und hatte dadurch die Möglichkeit auch im AK-Labor mit beiden Methoden zu arbeiten. Die Denitrifizierer-Methode wurde mir bei Dr. Jan Kaiser gezeigt. Vielen Dank für die spontane Möglichkeit zu euch zu kommen und für die viele Zeit, die ihr euch genommen habt, um mir die Methode zu zeigen! Many thanks to Laura Campisi who spent her precious time to teach us three phD students in the denitrifier method! Thanks to the School of Environmental Science of the University of East Anglia for giving me the opportunity to get practical experience in the denitrifier method. Das Arbeiten mit Pilzreinkulturen habe ich bei Dr. Gesche Braker am des Max-Plank-Instituts für terrestrische Mikrobiologie in Marburg kennen gelernt. Vielen Dank für deine Hilfe Pilzstämme zu bekommen und die Zeit, die du geopfert hast!

Dem Thünen-Institut für Biodiversität, besonders Prof. Dr. Tebbe, danke ich für die Bereitstellung von Arbeitsmaterial und für die Unterstützung bei der Umsetzung der Reinkulturversuche am TI. Für zahlreiche Gespräche mit hilfreichen Hinweisen, ohne die das mikrobiologische Arbeiten im Labor sehr schwer geworden wäre, danke ich Dr. Anja Dohrmann, Karin Trescher, Jana Usarek und Michael Hemkemeyer. Außerdem danke ich Prof. Dr. Stefan Schrader für die Bereitstellung des Autoklaven und anderen Labormaterialien.

Bei dem Versuchsgut Reinshof, der Versuchsstation Braunschweig vom FLI und der Familie Riechers bedanke ich mich für die Möglichkeit Bodenproben für die Inkubationsversuche zu bekommen.

Für Analysen von ${ }^{15} \mathrm{~N}$ in $\mathrm{N}_{2} \mathrm{O}$ und $\mathrm{N}_{2}$ und ${ }^{18} \mathrm{O}$ im Wasser danke ich dem KOSI der Universität Göttingen, vor allem Dr. Jens Dyckmans, Reinhard Langel und Lars Szwec.

Schließlich bedanke ich mich bei meinen Eltern und meiner Schwester für die Unterstützung! 